Flett, J. B. (John B.)

Features of the flors of

Mount Rainier National Park 



\section{FEATURES OF THE FLORA OF MOUNT RAINIER NATIONAL PARK}

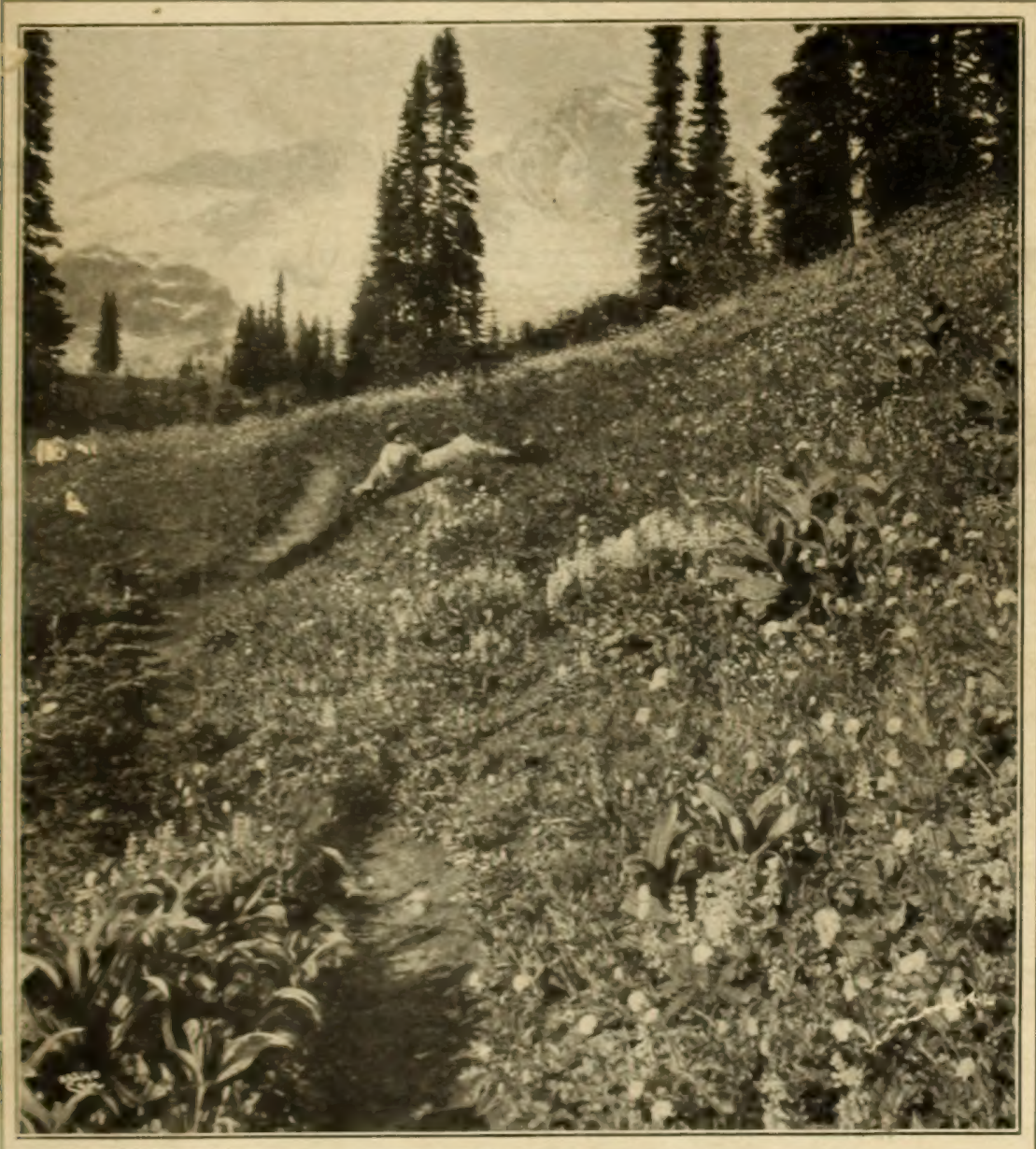

DEPARTMENT OF THE INTERIOR

OFFICE OF THE SECRETARY 
PUBLICATIONS OF MOUNT RAINIER NATIONAL PARK SOLD BY THE SUPERINTENDENT OF DOCUMENTS.

Remittances for these publications should be by money order, payable to the Superintendent of Documents, Government Printing Office, Washington, D. $\mathbf{C}_{\gamma}$ or in cash. Checks and postage stamps can not be accepted.

Forests of Mount Rainitr National Park, by G. F. Allen. 1916. 32 pages, including 27 illustrations. 20 cents.

Contains descriptions of the forest cover and the principal species.

Mount Rainier and Its Glaciers, by F. E. Matthes. 1914. 48 pages, including 26 illustrations, 15 cents.

Contains a general account of the glaciers of Mount Rainier and of the development of the valleys and basins surrounding the peak.

Panoramic view of Mount Rainier National Park, 20 by 19 inches, scale 1 mile to the inch. 25 cents. 


\title{
FEATURES OF THE FLORA OF MOUNT RAINIER NATIONAL PARK.
}

\author{
By J. B. Flett.
}

\section{GENERAL STATEMENT.}

In a general treatment of the flora of Mount Rainier National Park we must bear in mind the fact that the mountain is located near the center of the park and that the park extends down into the dense forest, thus giving a varied and extensive flora.

For convenience the park may be divided into five zones:

1. The lower area near the boundary, between elevations of 2,000 and 2,800 feet, is composed of wide river valleys covered with large trees around which are woven masses of moss, liverworts, lichens, and ferns. These plants also form a beautiful cover for the forest floor.

2. The upper forest region between elevations of 2,800 and 4,000 feet is characterized by trees covered with gray hanging forms of lichens, smaller trees, and a gradual transition to alpine types.

3. Between 4,000 and 5,500 feet trees are found in groups distinctly alpine alternating with grassy meadows.

4. From 5,500 feet to timber line.

5. Rocky ridges and pumice fields above timber line.

\section{THE FIRST ZONE.}

The first of these zones begins at about an altitude of 2,000 feet, which is the altitude of the river valleys. These valleys, which radiate from the mountain, are of glacial origin. They are broad at their lower ends, but as they approach the mountain they become more narrow and their sides are more precipitous. Aside from their shape the thing that strikes the careful observer is the splendid forest of large trees and the odd forms of plant life which form the beautiful Sf forest cover. These two conditions are nowhere seen to better Coadvantage.

- The principal tree in these valleys near the park boundary is the ( DDouglas fir, a well known tree, as it is the most common and the D. most valuable tree in the Puget Sound region. ${ }^{1}$ The stranger may

1 The forest trees are described in a publication entitled "Forests of Mount Rainier National Park," which may be purchased from the Superintendent of Documents, Government Printing Omice, Wash. ington, D. C., lot 20 cents. 
recognize it by its thick bark, cleft into long perpendicular furrows on the large trees, and by the leaves surrounding the branches, from which hang numerous cones with projecting bracts. The next tree in value is the white cedar, Thuja plicata. This is easily recognized by its arbor-vitae like foliage, its thin fibrous bark and spreading base. It is the only cedar or cedarlike tree in that forest until the upper limit where the Alaska cedar begins to come in. The lowland western hemlock is perhaps second in abundance. It may be recognized by its small cones and short foliage silvery white on the lower side of the branches and by its drooping plumelike top, while all the firs have erect tops. There are three true firs scattered through this forest, namely, the lovely, Abies amabilis, the silver, Abies grandis, and the noble, Abies nobilis. The lovely fir is sometimes called larch by the lumbermen, thus confusing it with a tree which does not grow on the western slope of the Cascades. The lovely fir has scaly bark somewhat like the spruce and a dome sbaped top. The foliage is not white underneath; the tree has large purple cones without exserted bracts, which grow only on the top of the tree. The silver fir grows rather sparingly throughout this zone. It can be recognized by its leaves, which are of three different lengths and twisted so that they lie nearly in the same plane on opposite sides of the branch, thus giving it a flat appearance. The branches are generally silvery white underneath, hence the popular name. The bark is often white, hence sometimes called white fir. It has small green cones without exserted bracts. This tree flourishes best among alder and cottonwood where there is an abundance of moisture and extends from sea level to about 4,000 feet. The lumber is classed with hemlock by the lumbermen. The noble fir is not abundant in this zone.

The deciduous trees of this zone are the broad-leafed maple, the vine maple, the alder, and cottonwood. The broad-leafed maples are noted for their dense foliage. In the dense forest of tall conifers they often take on an enormous growth of moss, liverworts, lichens, and ferns, which gives them a superficial resemblance to a tropical epiphytic forest, while the vine maples, small and tough, bend over to the ground, forming many fantastical curves and tangles almost impenetrable to the experienced woodsman. These tangles are often made up of several other troublesome shrubs, such as the devil's club, Echinopanax horridum, with its irritating spines, broad palmate leaves, and red berries. The cascara, an alderlike small tree, is noted for the medicinal qualities of its bark, which is collected in some localities and shipped in carloads to the eastern market. The willows, spiræas, huckleberries, and the dainty little pachistima are all more or less abundant in this dense forest area.

The herbaceous plants of this region are perhaps the most interesting, because of the many odd forms. The strangest of these belong 
to a group of plants which live on decayed matter. They have lost all green coloring matter which is necessary for self-support and live on the products of other plants. The best known of these strange denizens of the forest is the Indian pipe or ghost plant Monotropa uniflora (fig. 1). The former common name is applied to it because of its

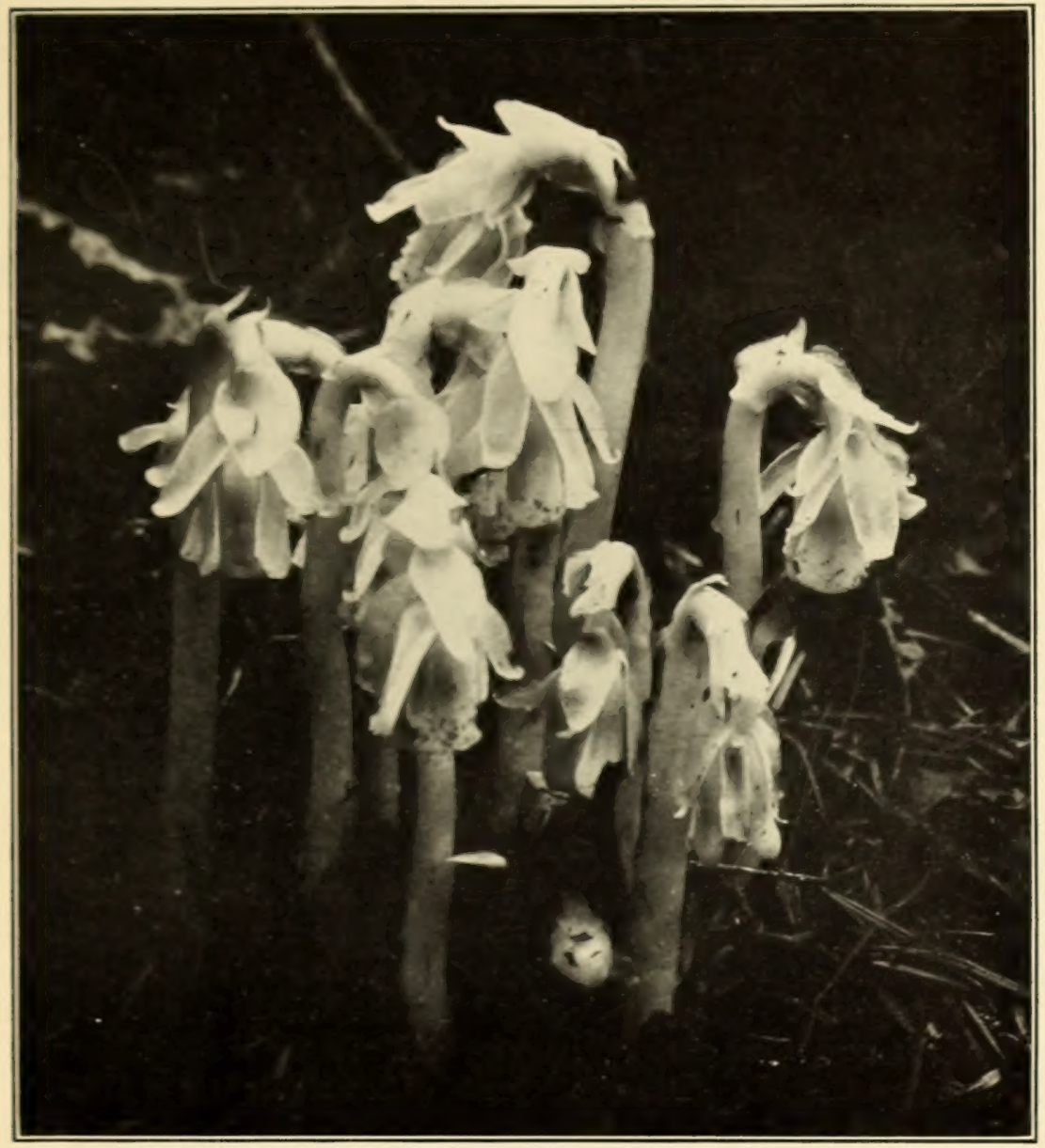

Fig. 1.-Indian pipe or ghost plant (Monotropa uniflora).

Color of flower, white; height of plant, 5 to 12 inches; blooms July and August.

Photograph by Asahel Curtis.

fancied resemblance to the ordinary clay pipe, the latter because of its pearly whiteness. This plant has a wide range, extending all over the United States wherever the proper conditions are found. Nowhere is it more at home than in the woods of Washington and Oregon. There is another plant of the same genus which has several flowers on the same stem; this is popularly called the many-flowered Indian 
pipe, while the plant having only one flower is called the one-flowered Indian pipe. The one-flowered species grows in dense clusters, while the other has not this tendency.

The Allotropa, or barber's pole (fig. 2), is a beautiful red and white striped plant confined to the forest of the Pacific coast. It is, perhaps, the oddest of this strange group, because of its bright colors.

The pine sap, Pterospora andromedea (fig. 2), may be recognized by its reddish-brown stem, 3 or 4 feet high, without leaves, and by the numerous globular flowers arranged along the upper part of the stem. This plant, like the Indian pipe, has a wide range, extending across the continent. Locally it extends from about 1,000 feet above sea level to about 3,800 feet. The rarest of this leafless group is Hemitomes congestum (fig. 2). It is so rare that it has no common name. Like the one-flowered Indian pipe, it grows in dense clusters. The writer saw one bunch collected below the park entrance that filled an ordinary milk pan. Not only do these plants grow in dense masses but the flowers on each plant are also massed together, as the specific name indicates. In its prime it is a beautiful rose-pink or sometimes nearly white, but with age it turns black like nearly all of the Indian pipe family. It extends from near sea level to an altitude of about 3,200 feet. On the southeast slope of Mount Angeles, near an old deserted cabin, the writer found the five species shown on figure 2. The plants were collected and placed hurriedly on an old table and photographed with the side of the log cabin for a background.

Closely related to this leafless group is the Pyrola or wintergreen family, which is well represented and seems to be a connecting link between the Indian pipe family and that of the heath or heather family. In the old textbooks all three families are included in the heath family. The name pyrola means a little pear, from the fact that the thick shining evergreen leaves resemble those of a pear tree. These species are easily recognized in the dense forest. Pyrola secunda is known at once by its one-sided raceme of small greenish flowers or seed-pods. The wintergreen of commerce is not obtained from any of the western species, but from the false wintergreen or checkerberry of the East. This plant is more abundant in the second zone. Pyrola aphylla, as the specific name indicates without leaves, has small bracts. Pyrola bracteata has rather large round or elliptical leaves in a rosette with flowers in a raceme. This plant resembles the eastern "shin-leaf." Still another, Pyrola picta, might be added. This may be recognized by the white spots or streaks in its rather long leaves. Moneses uniflora is a beautiful little plant of this small family. It may be known from the pyrolas by its single waxy flower. Its generic name signifies "delight." It is needless to add 


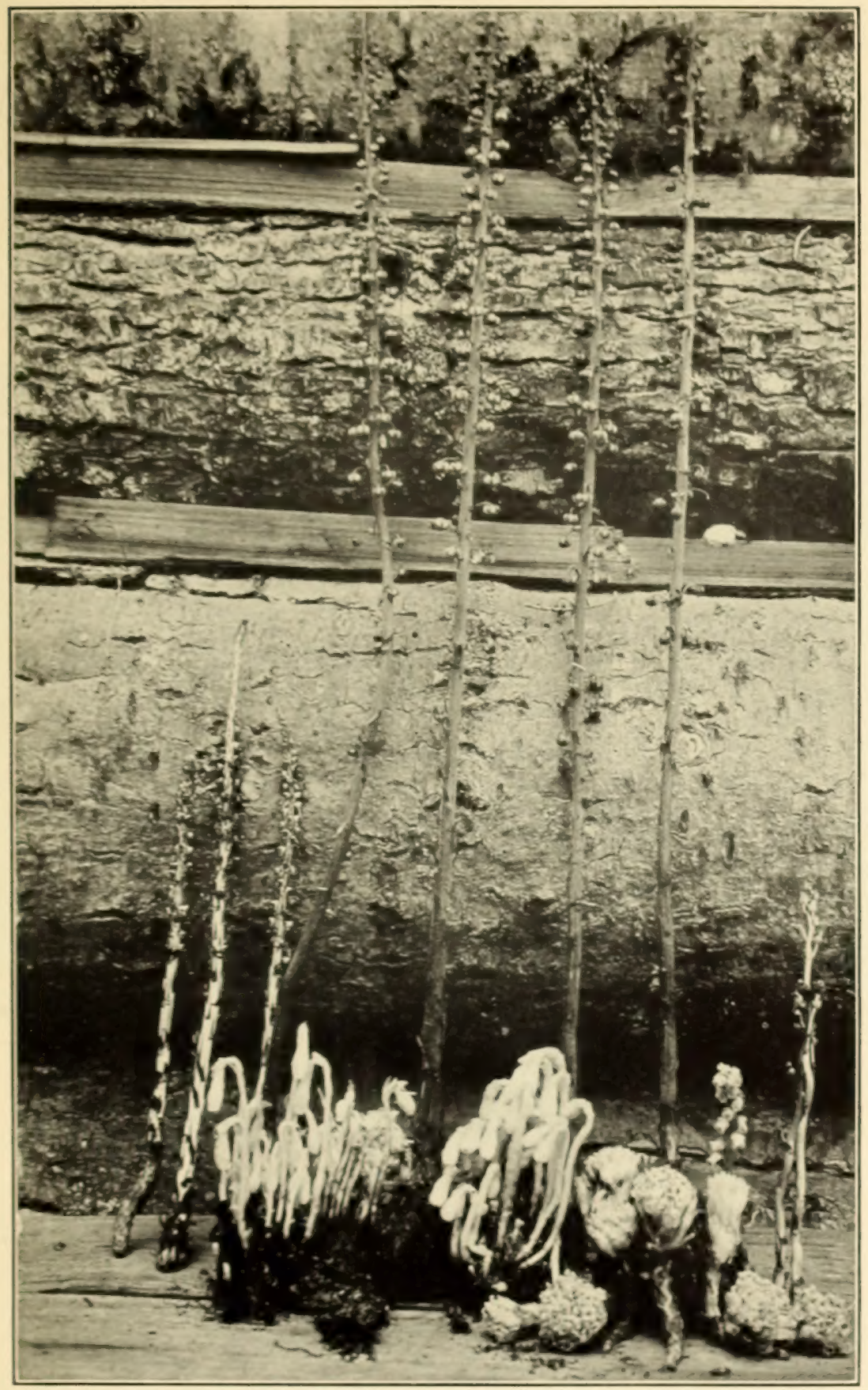

Fig. 2.-Barber's pole (Allotropa virgata) on left; ghost plant or Indian pipe (Monotropa uniflora) to right of barber's pole; many-flowered Indian pipe (Hypopitys hypopitys) on right; Hemitomes congestum, massive flower near right corner; pine drops or pine sup (Pterospora andromedea), tall plant against logs in background. 
that it is worthy of its name, as it will surely delight the heart of its finder.

To this family also belongs the prince's pine or pipsissewa, which is common in these mossy woods. It is a more robust plant than the pyrolas, with narrower oblanceolate leaves and an umbel of waxy

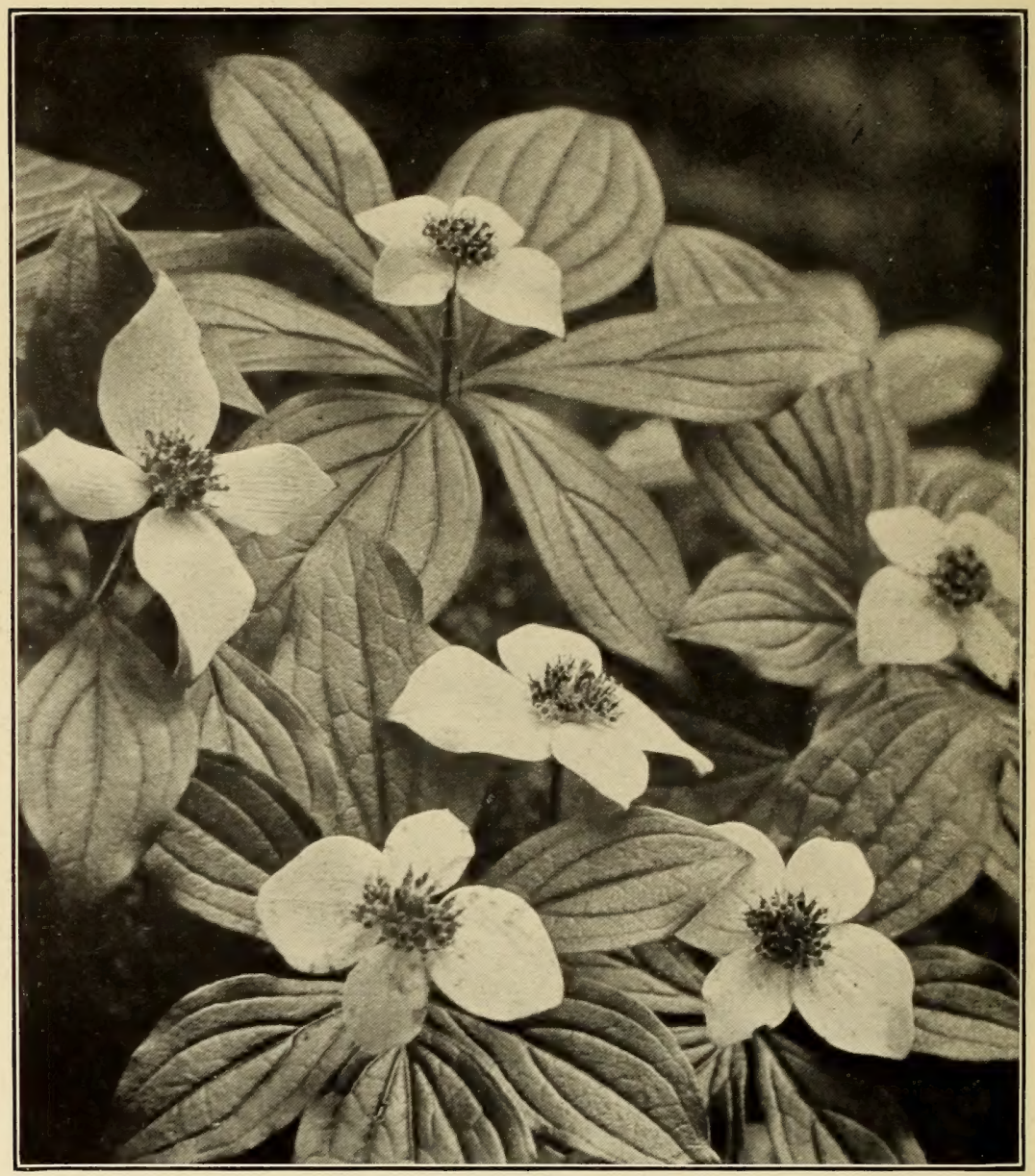

FIG. 3.-Canada dogwood (Cornus canadensis).

Color of flower, greenish white; height of plant, 3 to 8 inches; diameter of head, $:$ to 1 inch; blooms June to November.

Photograph by A. H. Barnes.

flowers. It is common through the United States and Canada. Menzies's prince's pine is a much smaller plant with variegated leaves and is restricted to the West. This, like most of its relatives, has somewhat waxy flowers. In localities where the soil is poor the salal, a plant which is nearly always present in the fir woods, is abundant. It has leaves somewhat the shape of the trailing arbutus 


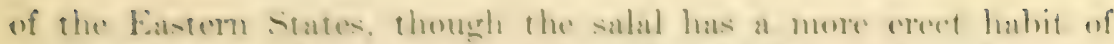

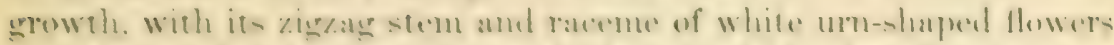
and blush-hlach berries. The red, hlath, amel blue huekleberies are

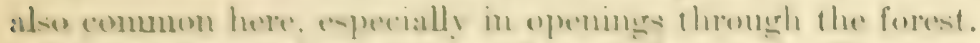

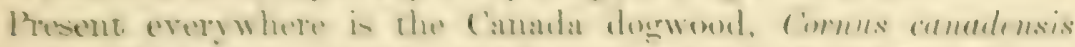

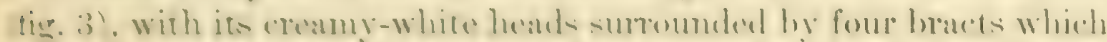

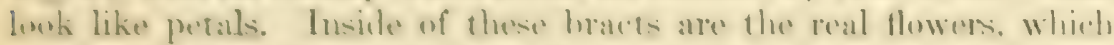
are small. It is dittiente to well whethere this phant is more beatuiful in flowere or in fruit. 'The fruit con-iste of a beatiful bunch of bright

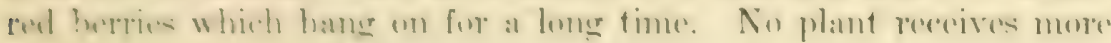

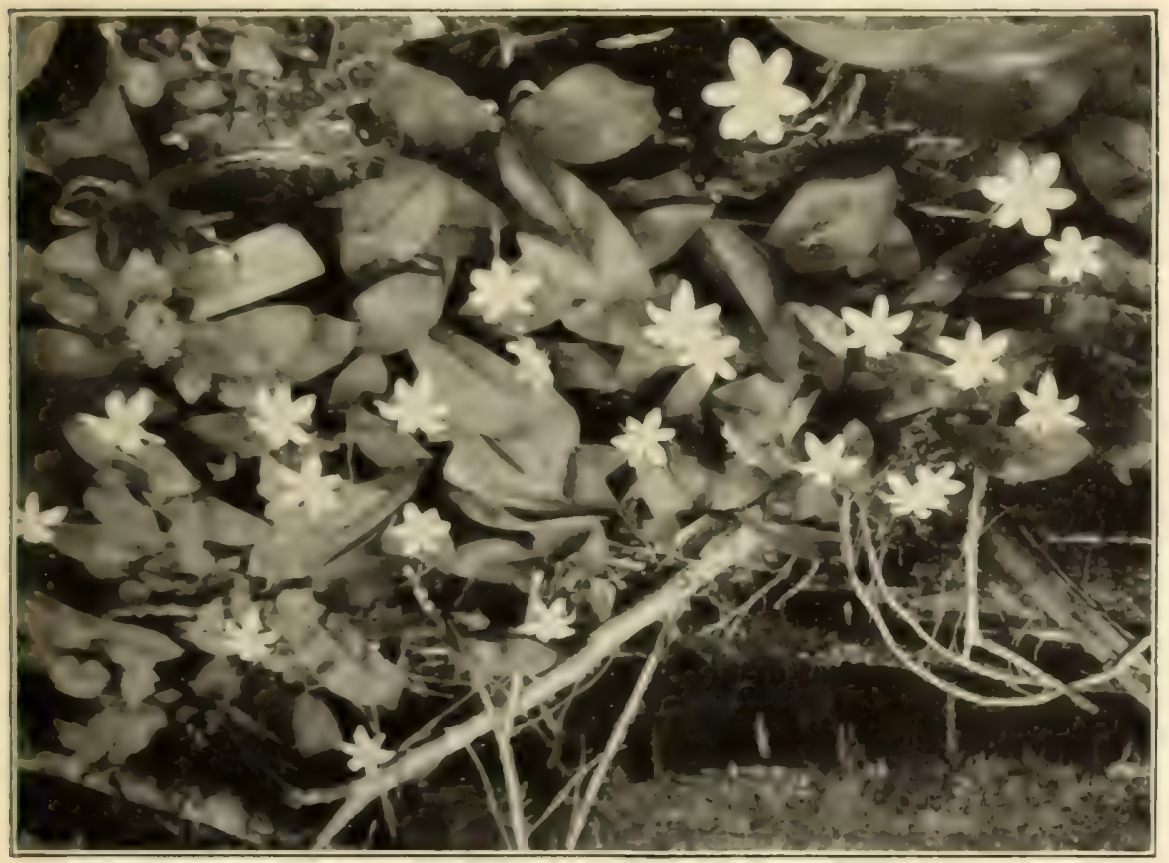

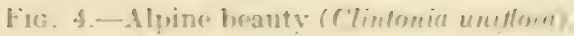

folot of flower, white: heicht of plant. 2 to 1 inches: lylom. July and August

I :. ineraph by J. B. I l..' .

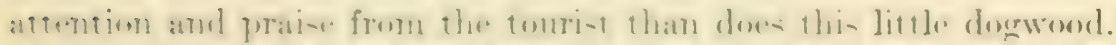

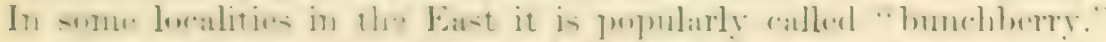

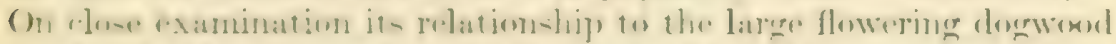

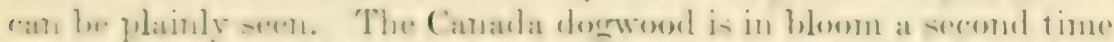

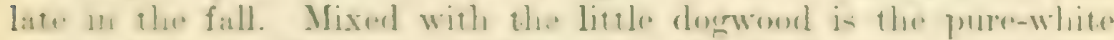

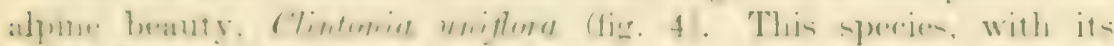

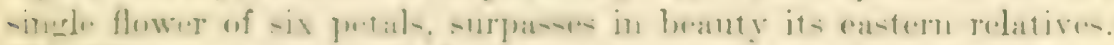

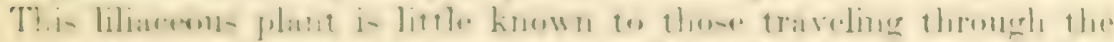

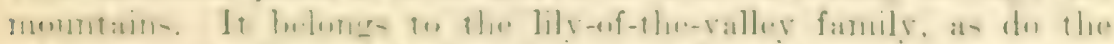

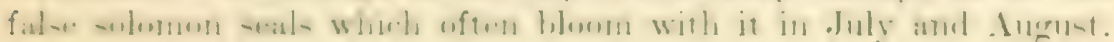


The Clintonia has three radical elliptical parallel-veined leaves and a single terminal flower. Its fruit consists of a blue berry. There are three species of the false solomon seal in this region-two species of twisted stalk and the ovate trillium-all of which belong to the lily-of-the-valley family.

The Oregon wood sorrel, Oxalis oregona, is extremely abundant and grows with those just mentioned. It has white or pinkish-white flowers and leaves of three obcordate leaflets resembling clover. The juice of this plant is extremely sour. Visitors frequently refer to it as that "cloverlike plant in the woods." A bishop's cap, Tiarella trifoliata, has a delicate raceme of small white flowers and pubescent

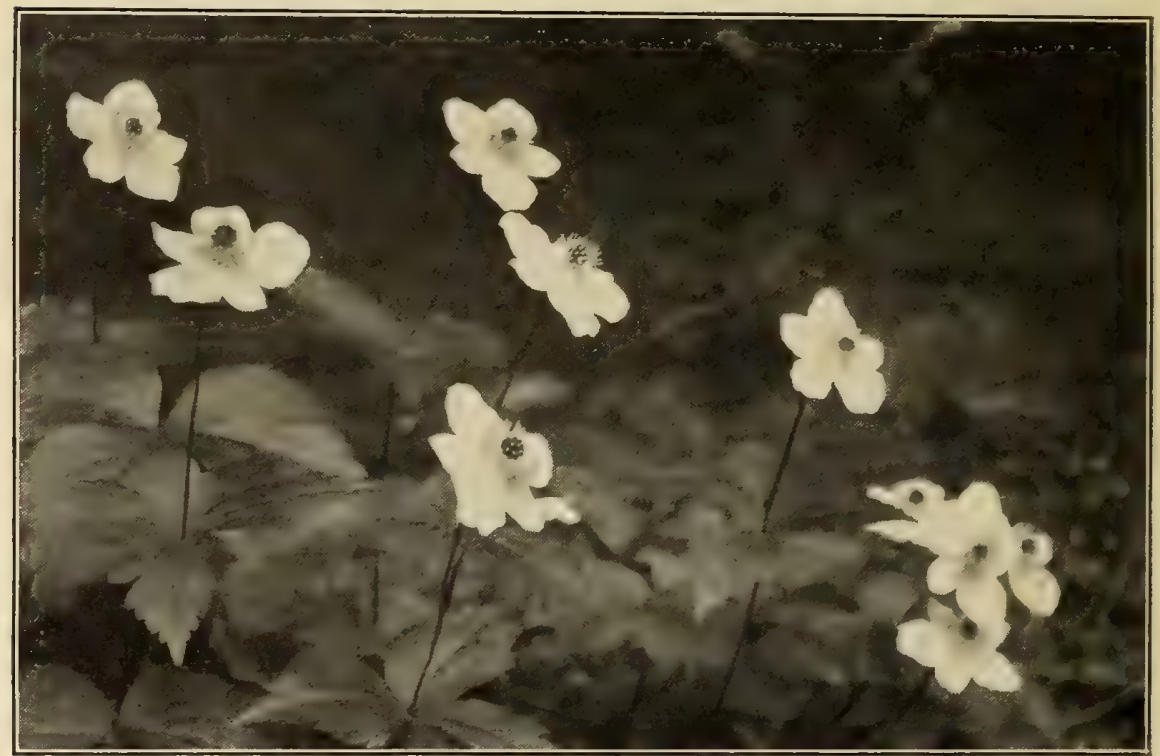

FIG. 5.-Forest anemone (Anemone deltoidea).

Color of flower, white; height of plant, 6 to 11 inches; blooms June to August. Photograph by A. H. Barnes.

trifoliate leaves. This plant extends from sea level to about 2,900 feet, when its leaves appear gradually to change from their trifoliate character to unifoliate. All intermediate forms can be found. When the transition is complete it is rechristened Tiarella unifoliata. It extends in this form to the terminal moraines of the glaciers or above.

The forest anemone, Anemone deltoidea (fig. 5), forms beautiful spots here and there because of its creeping roots, which tend to intertwine and bring the slender stems together. The leaves are rhomboid serrate with trifoliate leaflets. The delicate white flowers last a long time here in the dense shade. The fruit is not conspicuous, like that of its relative, the western anemone (figs. 6, 7, and 8), in the grassy meadows. 


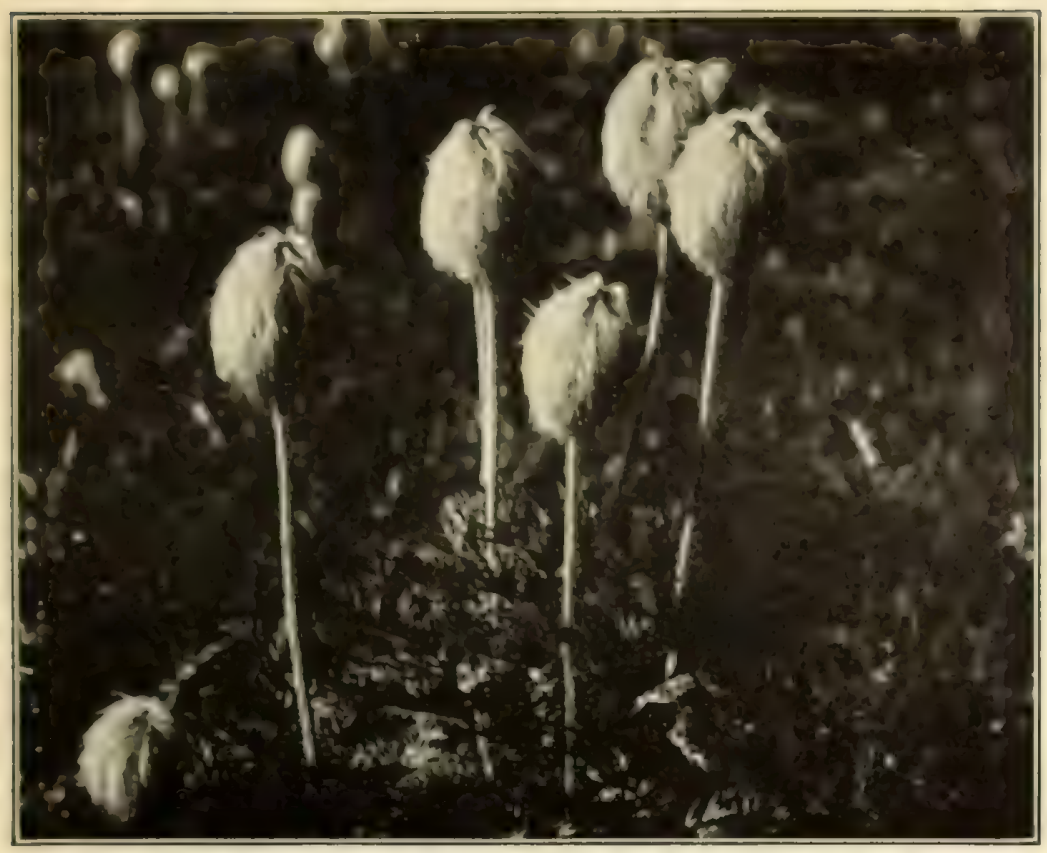

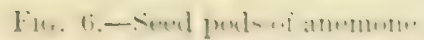

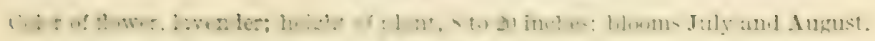

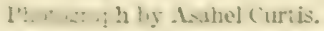

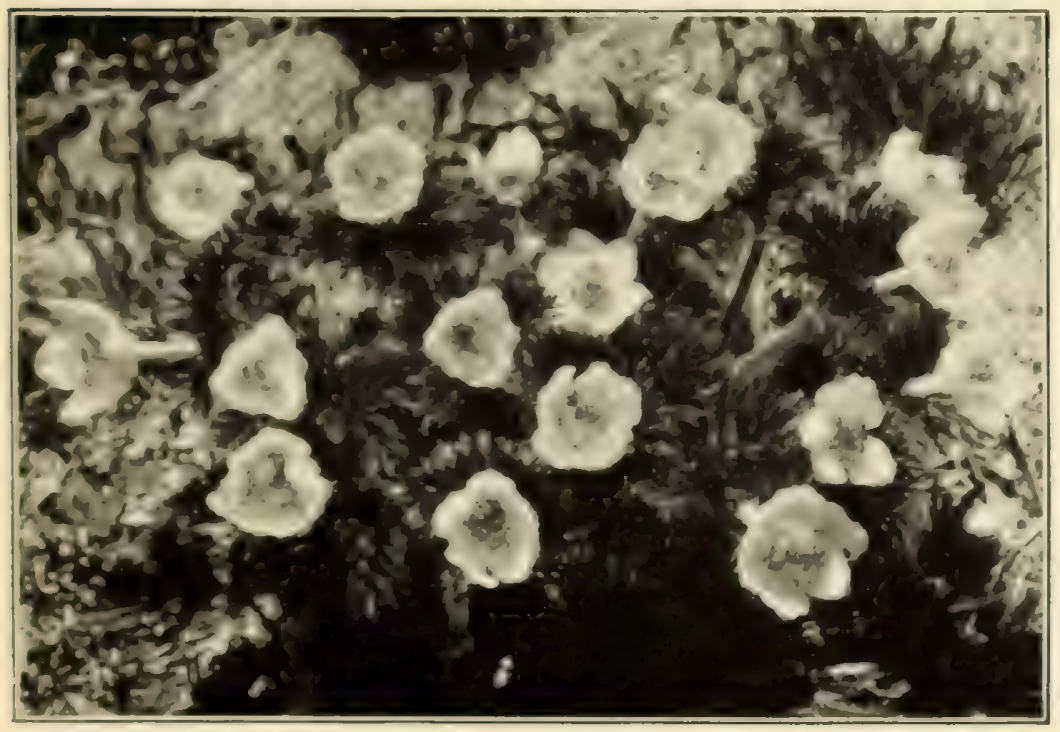

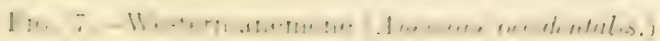

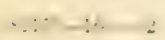




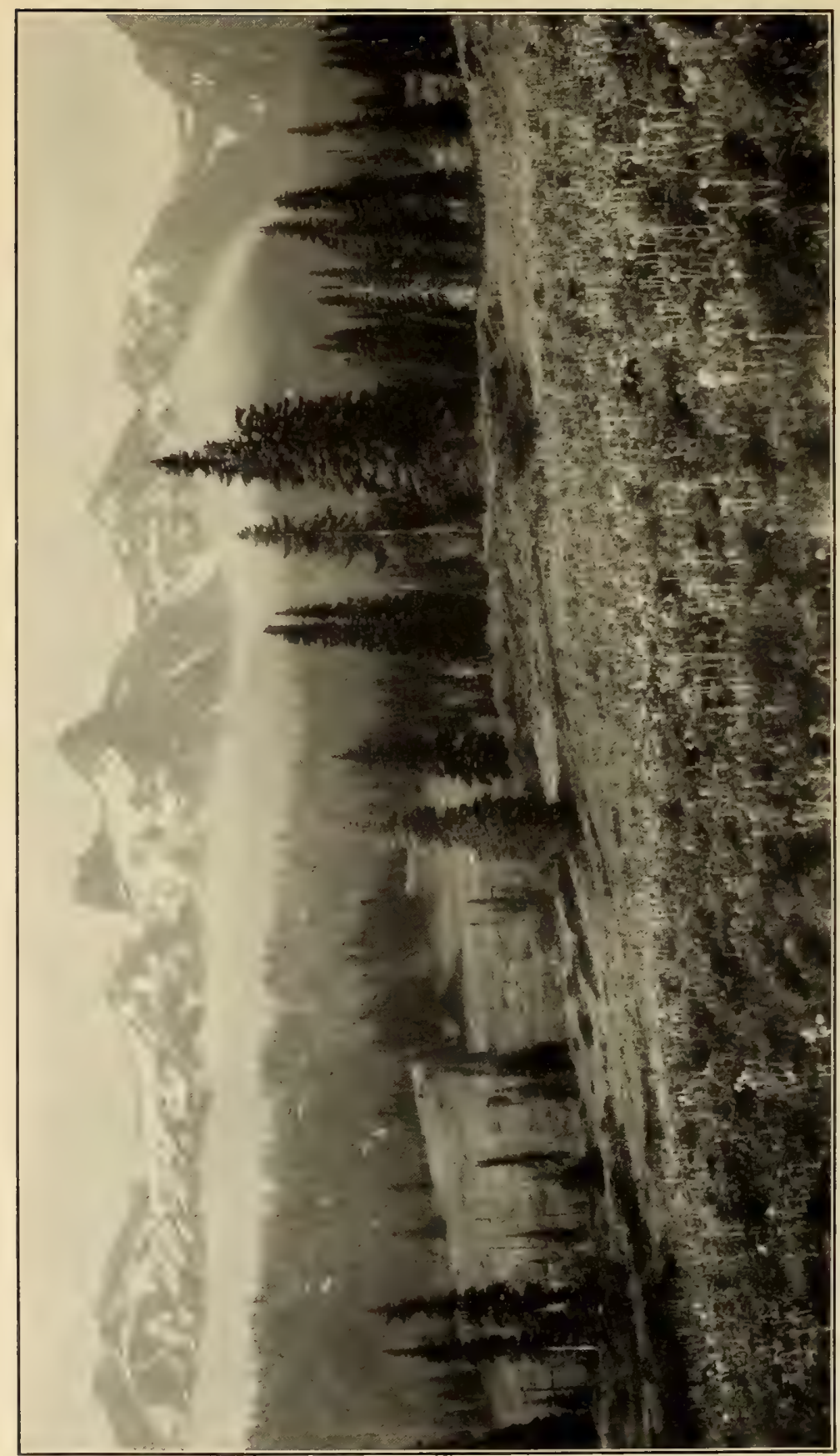

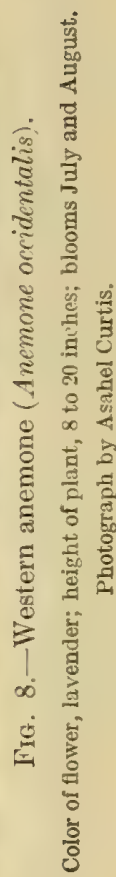




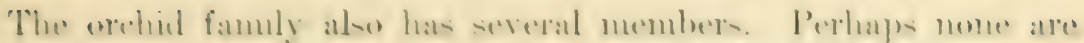

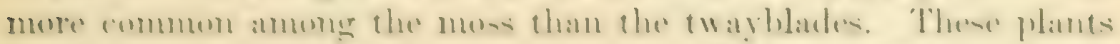

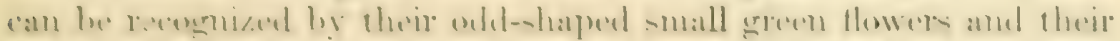

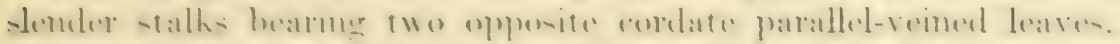

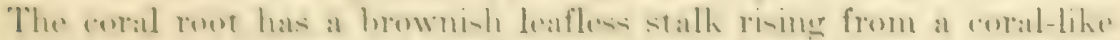

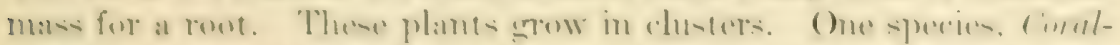

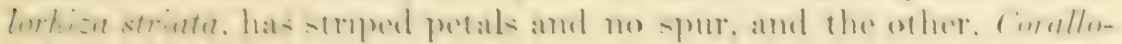

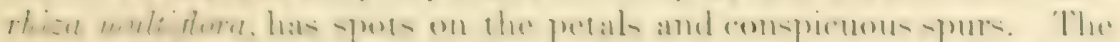

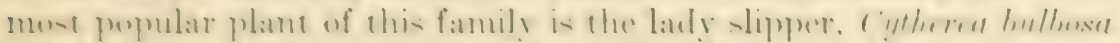

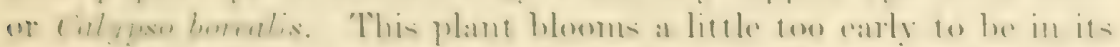

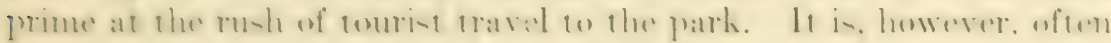

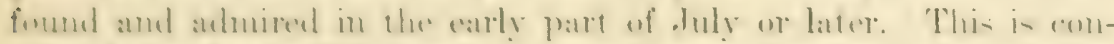

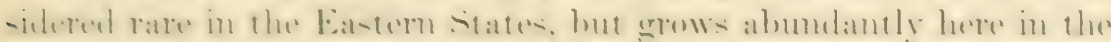

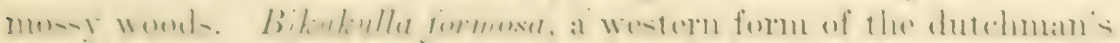

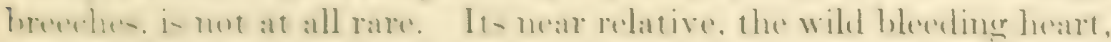

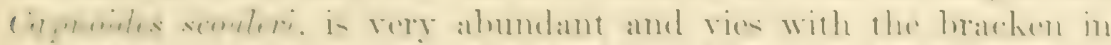

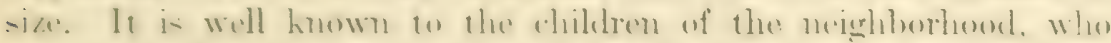

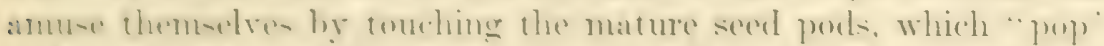

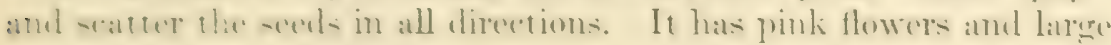
triangular leaves.

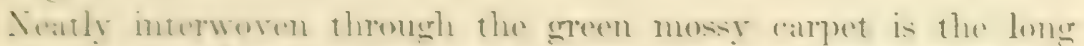

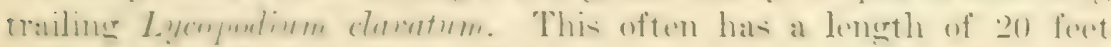

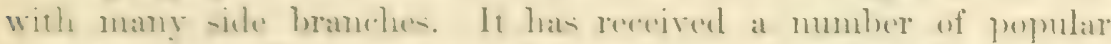

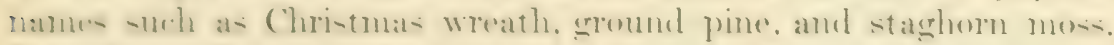

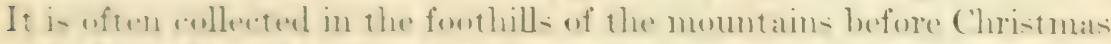

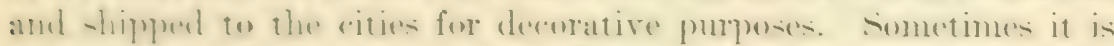

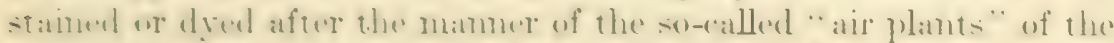
Japamede and woren arommel pillars or strume from one plater to

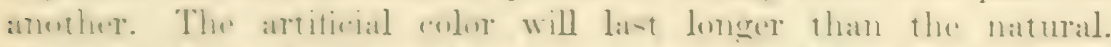

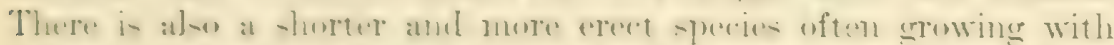

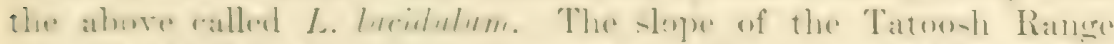

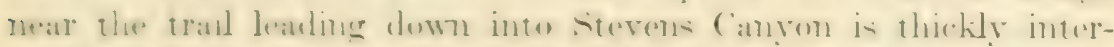

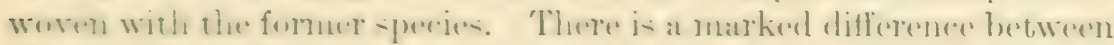

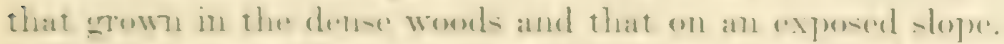

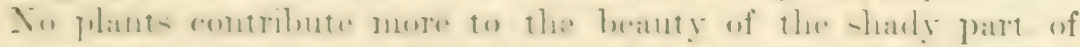

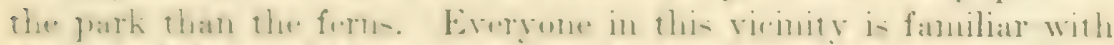

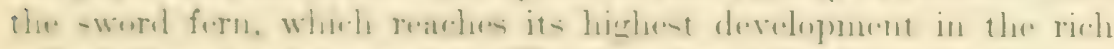

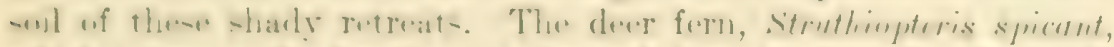

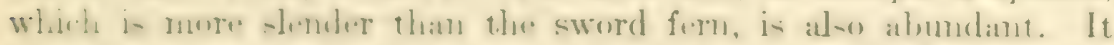

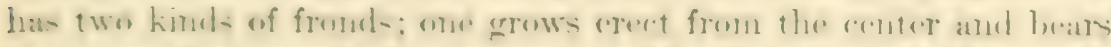

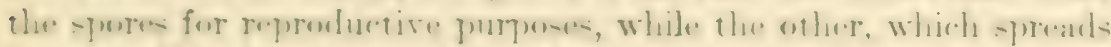

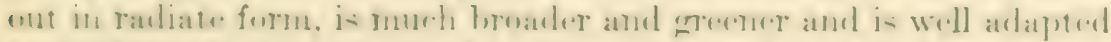

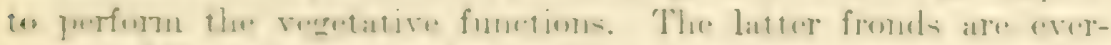

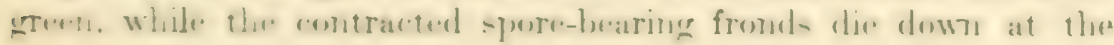


close of the season. The licorice fern, Polypodium occidentale, grows embedded in moss-covered trees and sometimes on old logs, while the maidenhair fern selects waterfalls and moist cliffs.

The common brake grows abundantly all through the lower zone and sometimes forms thickets with other vegetation. The western form of the lady fern sends up its tall broad fronds in tufts here and there, generally where there is an abundance of moisture. Somewhat resembling the lady ferm is Dryopteris spinulosa ditatata, which generally grows in similar localities. The lady fern is smoother than Dryopteris spinulosa dilatata and has kidney-shaped fruit dots on the back of the frond, while the fruit dots on the latter are round. The dainty oak fern, Phegopteris dryopteris, is everywhere present among the moss. It has a dark-colored stem and triangular frond. It is much smaller than the two last mentioned and extends into the higher portions of the park.

\section{THE SECOND ZONE.}

There can be no sharp line of demarcation separating the first and second zones, yet no one can fail to note the difference in the flori in a few hundred feet of ascent. There is, for instance, a difference between the park entrance and Longmire Springs. The trees as a rule have become smaller except along the border of the low swampy ground adjoining the Longmire property and its continuation up along the Henry Hunting Ground trail. Not only have the trees become smaller, but different species have come in. The white pine, Pinus monticola, occasionally seen below, now becomes common. It can be recognized by its fine silky foliage, its large cones and five needles or leaves in the bunch. On the pines the leaves are never separate as on the fir-, but are apparently tied together at the base and inserted into the branch. 'The bark of the white pine resembles a checkerboard. The black pine has two short leaves together. At Longmire Springs the white and black pines grow side by side. The black pine has dark foliage and numerous small prickly cones about an inch or two in length while the white pine has cones 8 or 10 inches long without spines.

The common and the Alaska cedars also have a common meeting ground here. The Alaska cedar has globular fruit which distinguishes it from the white cedar. After a little practice the two species of cedar can be distinguished by their bark and foliage. The wood of the Alaska cedar is yellow with a characteristic odor and becomes hard when dry, in marked contrast to the soft wood of the lowland cedar. In this vicinity the Alaska cedar seldom reaches 3 feet in diameter, though occasionally old fallen logs of far greater diameter are found in low places in the forest. The lumber 


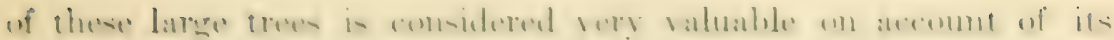
haretuesis and fine gr:tin.

()n aceount of the charaeter of the soil the trees mentioned

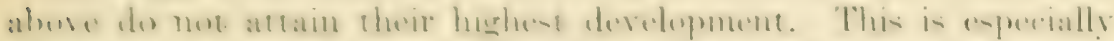

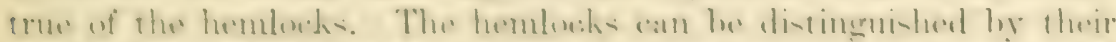

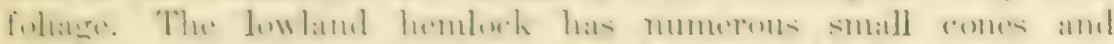

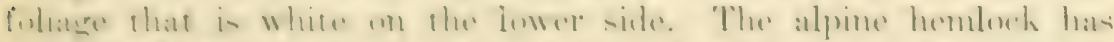

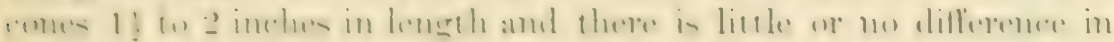
the color of the upper and lower sides of its folinge.

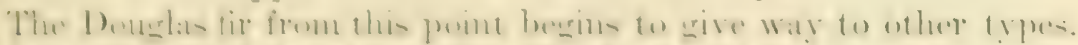

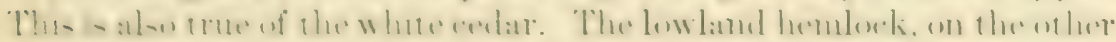

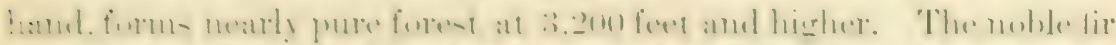

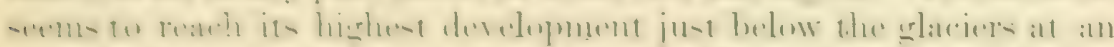

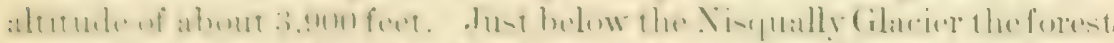

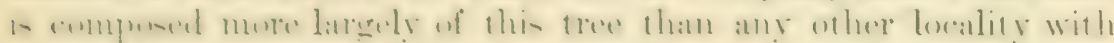
which the writer is familiar. In the distance these trees can be

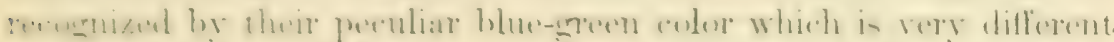

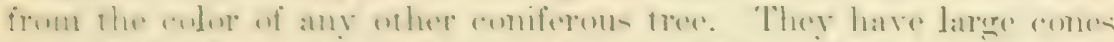

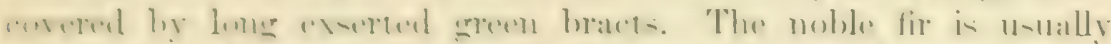

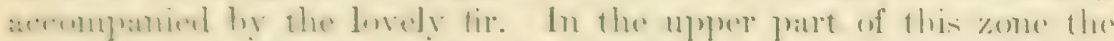

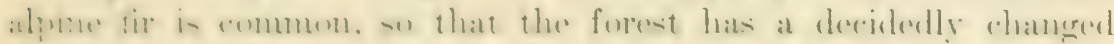

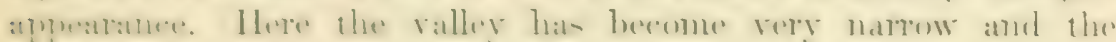

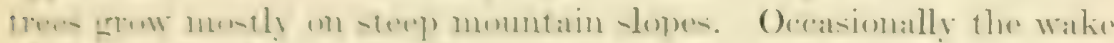

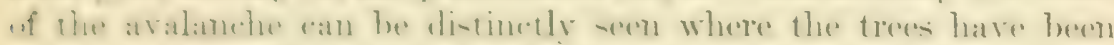

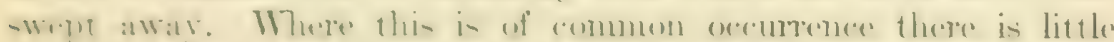

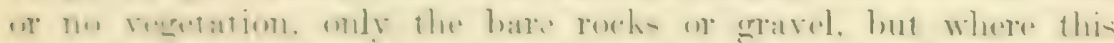

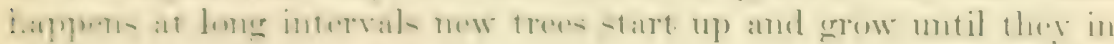
tumi may be destroved.

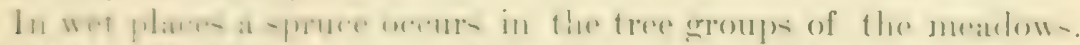

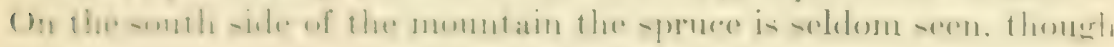
it is conmon on the north and east sides.

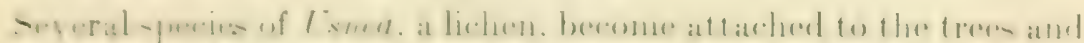

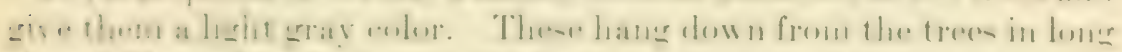

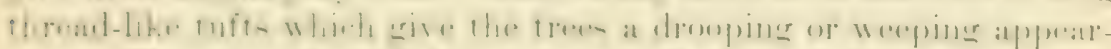

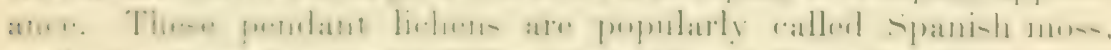

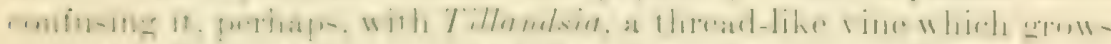

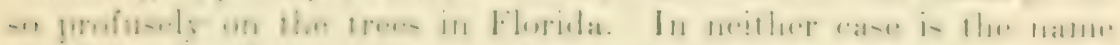

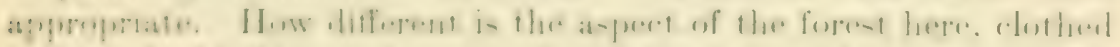

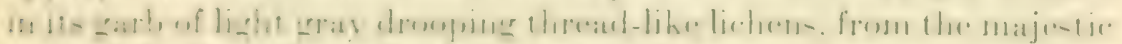

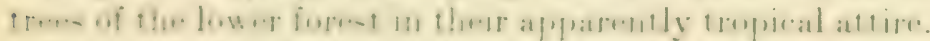

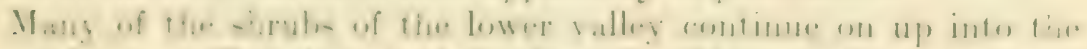

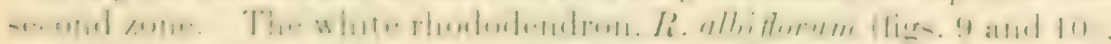

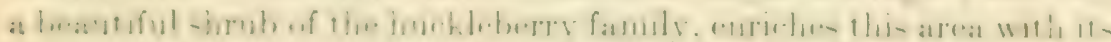

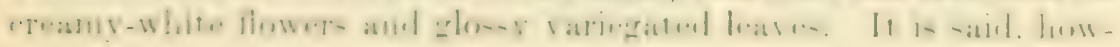




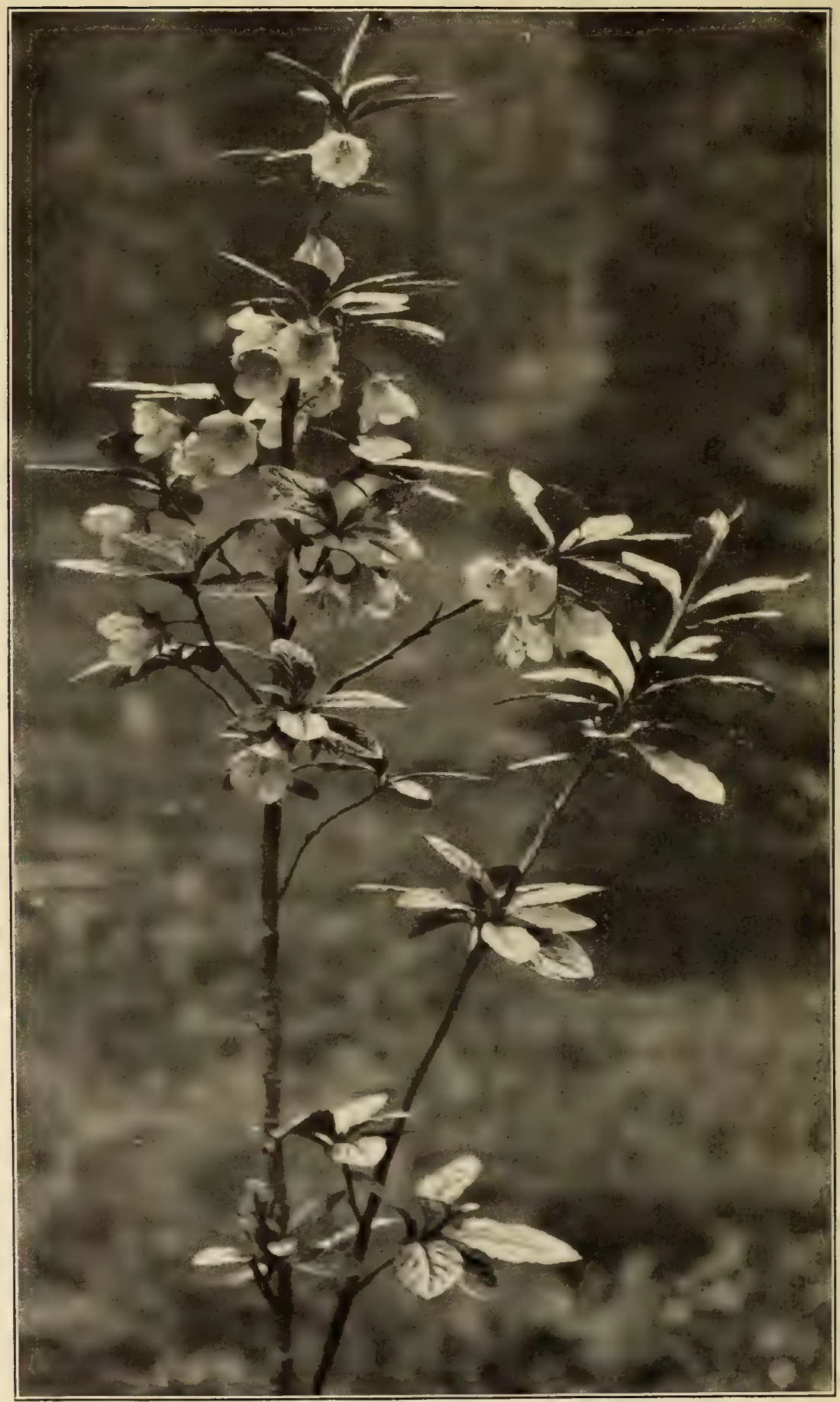

FIG. 9.-White rhododendron (Rhododendron albiflorum).

Color of flower, white or greenish white; height of plant, 4 to 6 feet; blooms July and August. Photograph by A. H. Barnes. 
erer, to be poisonous to sherep and other animals. The mountain ash,

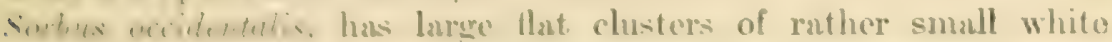
Howers and compound leaves. This is also much admired in the late

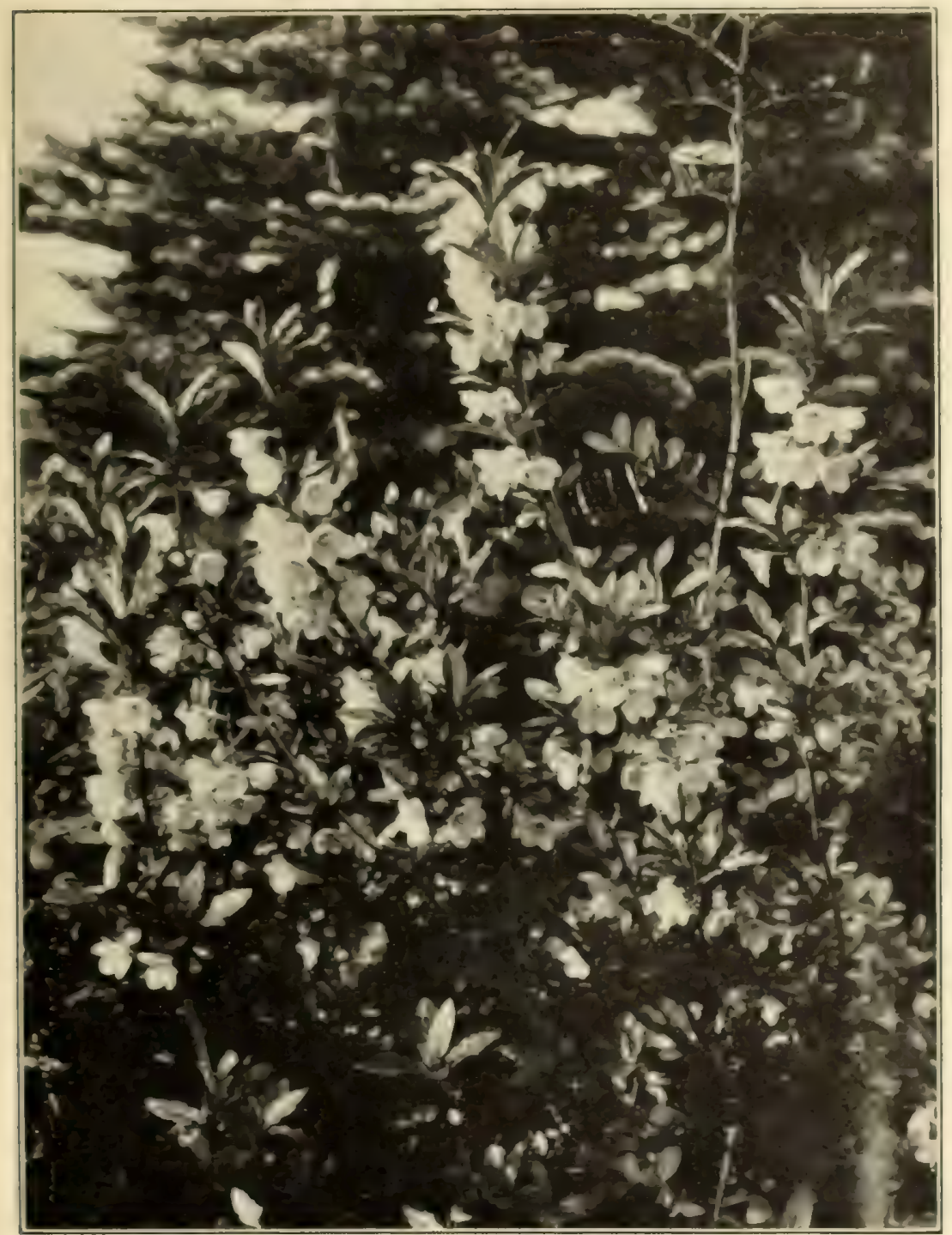

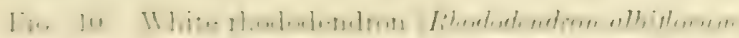

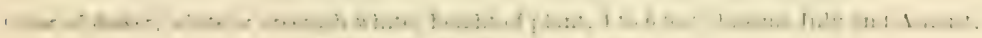

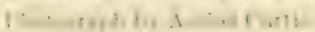

fall and early winter berante of its bright red berries which hang wh the-lirub for a don: tinte undess devoured by the birds. The camp rwhiter-and ('lark's crow see that these berries do not stay on too long. 
The orate-leaved salal, Gaultheria ovatifolia, occurs here among the moss. It is much smaller than its lowland relative and lies closer to the ground with its zigzag stem, ovate leares, and small white urn-shaped flowers. These plants will leave a photograph of themselves on white paper when pressed, thus showing the presence of oil. In case of a forest fire both species of these plants take fire readily because of their oily nature and do much to increase the rapidity of

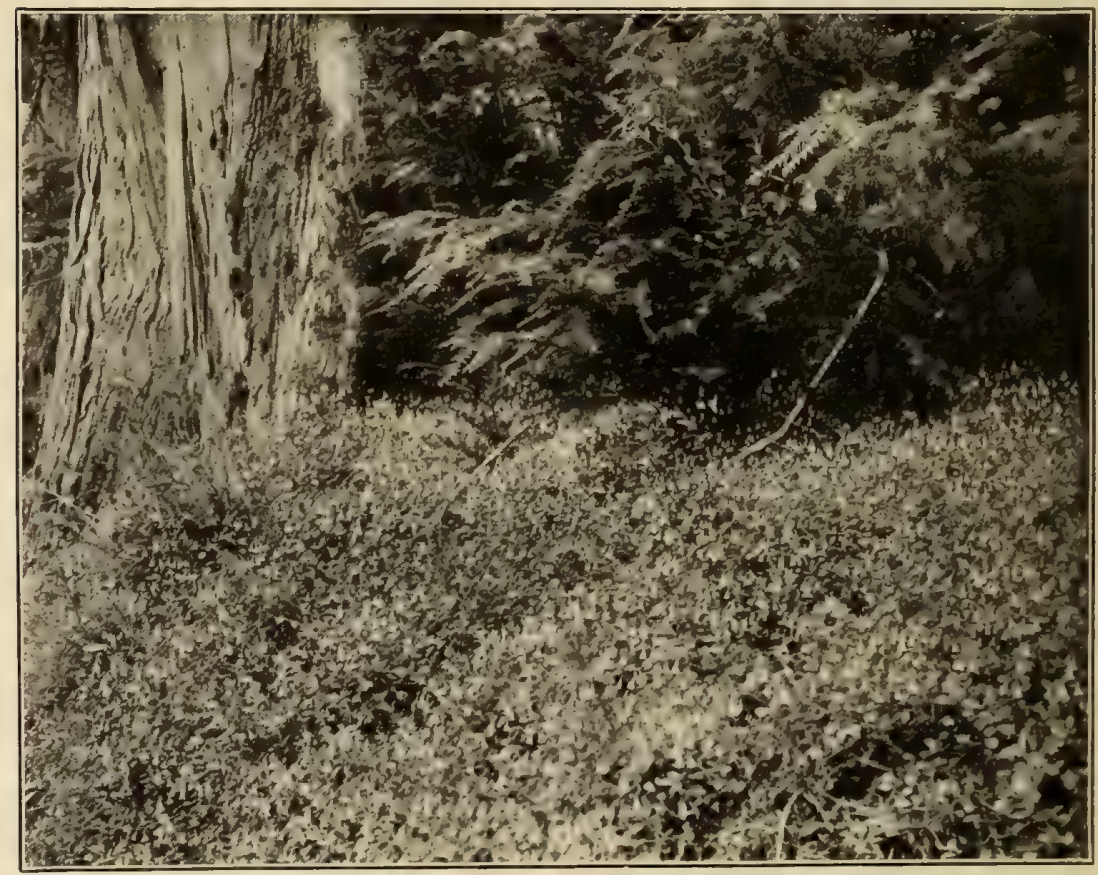

FIg. 11.-Twin-flower (Linnaer americana.)

Color of flower, pink; plant trailing on the ground, ete; hlooms July and August. Photograph by A. H. Denman.

the fire over the forest cover. They burn with an explosive crackling sound.

The twin-flower, Linnara americana (fig. 11), is one of the most dainty and graceful of our trailing vines. Trailing vines are rather rare in this region as are plants with much fragrance. This plant can be detected by its odor long before it is seen. It has two graceful, pink bell-shaped flowers near the end of each branch. These vines grow in radiating lines and its connection with the honeysuckle fanily can be seen both by its creeping stems and its fragrance. This plint is named in honor of Linnæus, the great Swedish botanist. It has a wide runge extending across the continent. Locally, it extends from sea level to about 4,000 feet, reaching its highest development about 2,800 feet. 


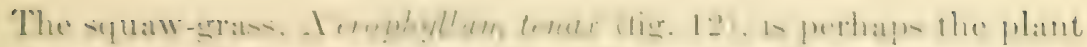

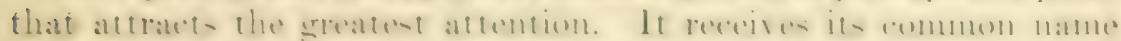

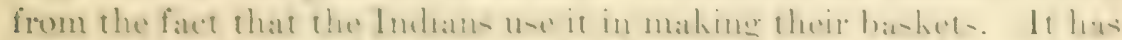

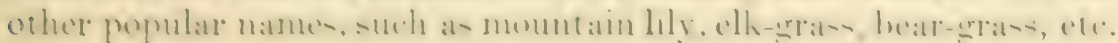

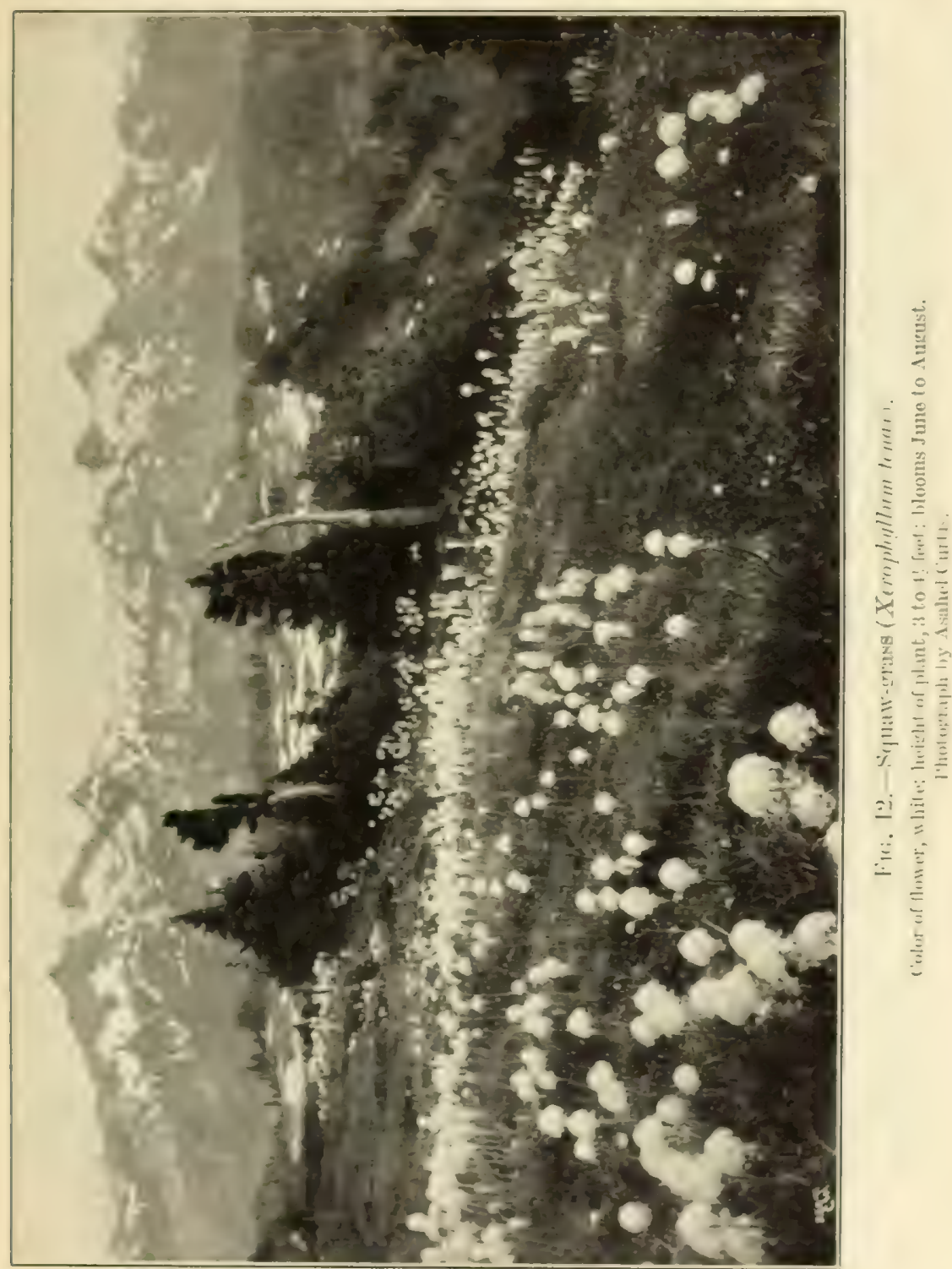

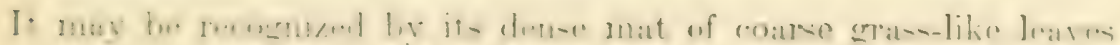

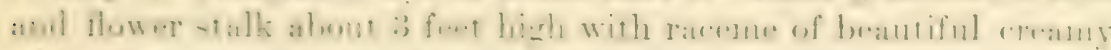
whit. flowers. In the early staces of develomment the flowers are

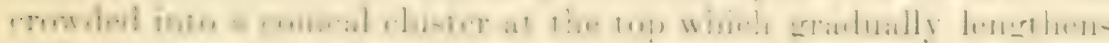


out until the stalk is nearly uniform with flowers on all sides. This, like the twin-flower, is very fragrant. In places where the trees are small this plant grows abundantly, generally in volcanic ash soil.

With it may be found the pyrolas, pipsissewas, and mertens' coral root, Corallorhiza mertensiana. The latter may be recognized

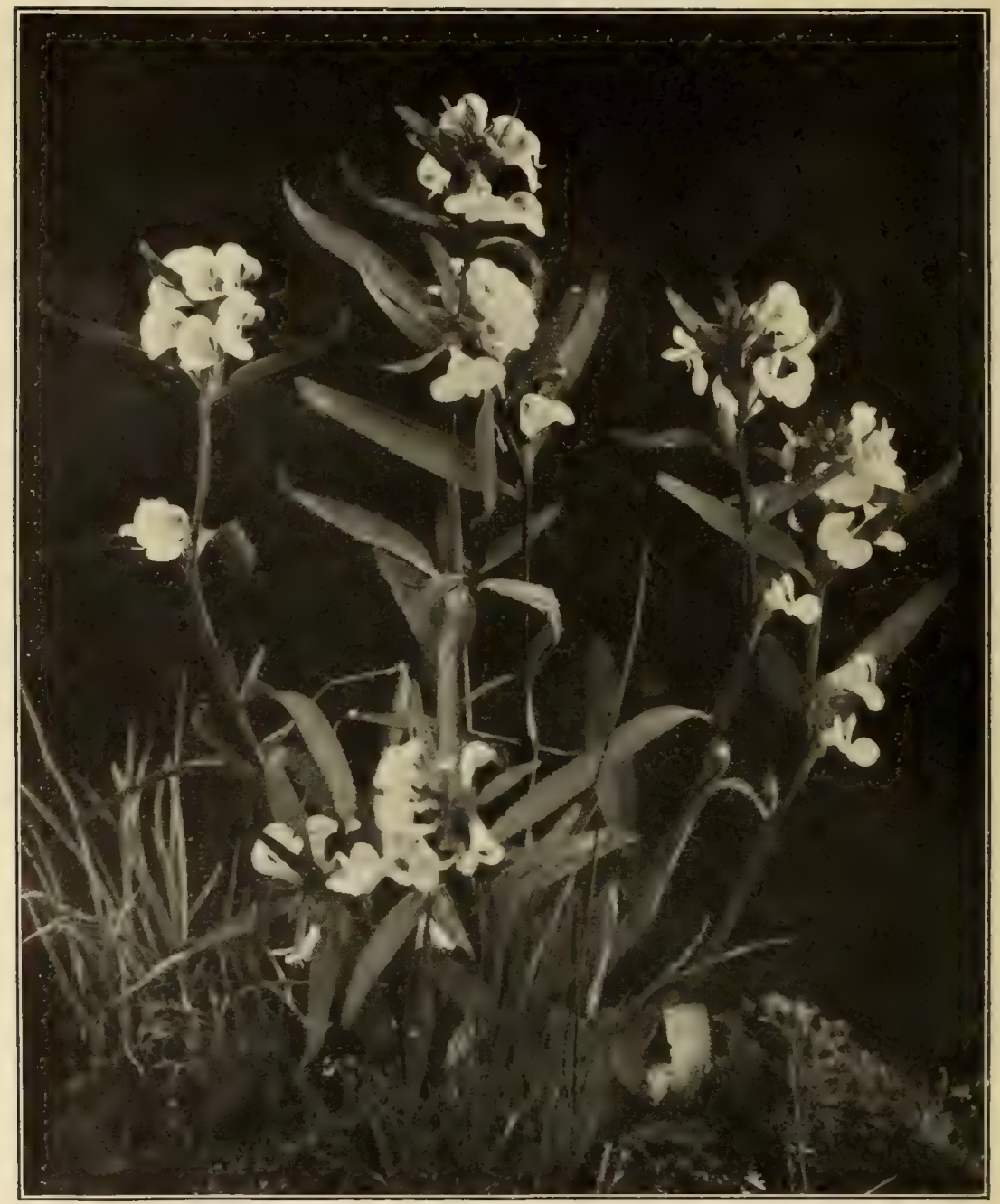

FIG. 13.-Common lousewort (Pedicularis racemosa).

Color of flower, pinkish white; height of plant, 5 to 8 inches; blooms July and August. Photograph by A. H. Barnes.

by its leafless stalk, coral-like roots, and strange pink flowers in ricemes. This saprophyte grows in clusters like the other coral roots and is a characteristic plant of this region. Several of the leafless plants mentioned in the first zone extend well up through the second. 


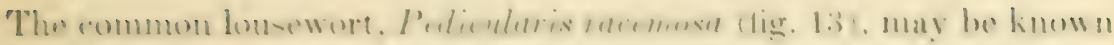

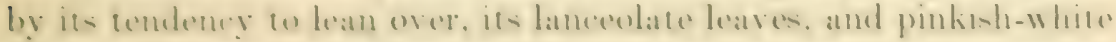
flowers. It usually grows in radiate clusters.

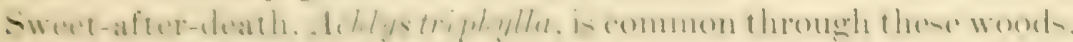

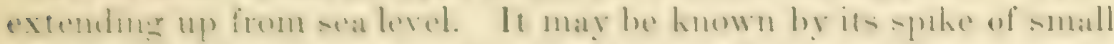

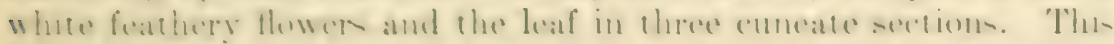

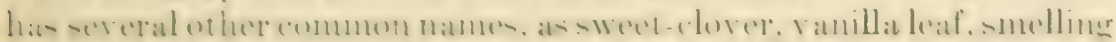

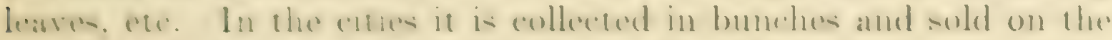

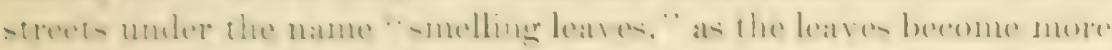
fragrant as they dry.

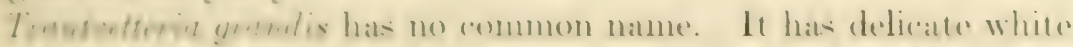

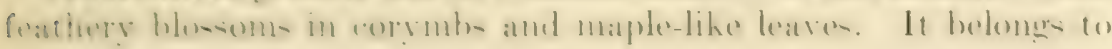

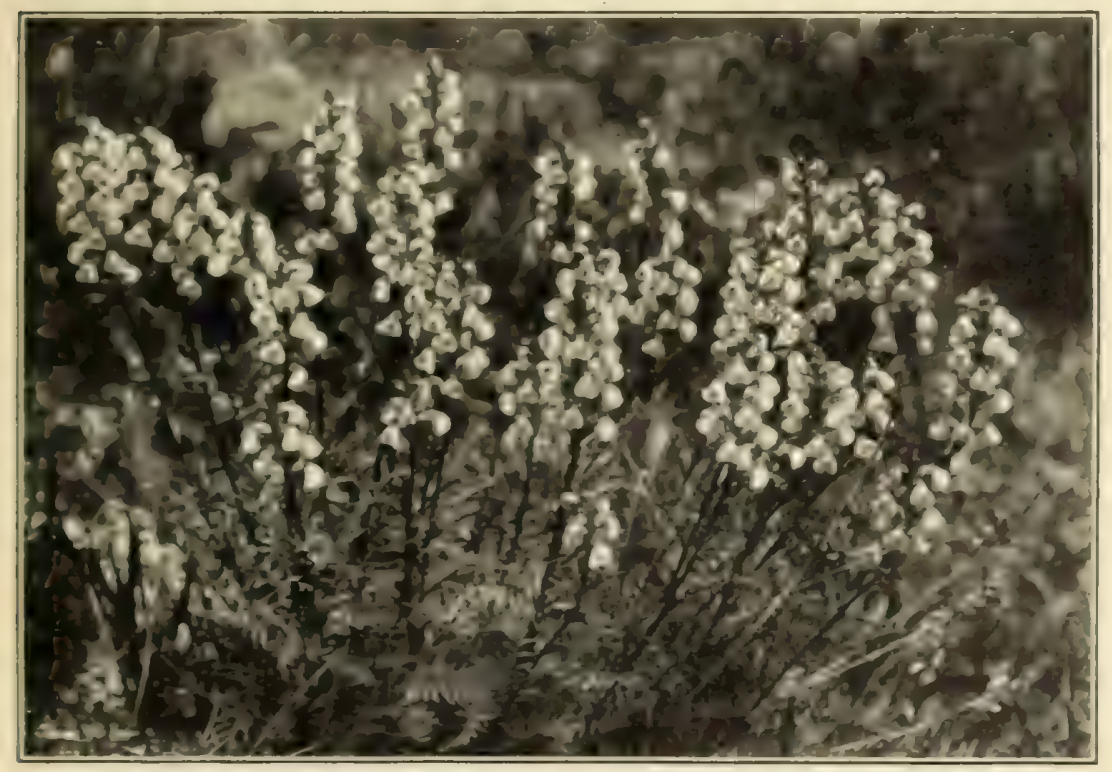

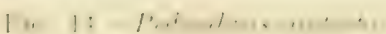

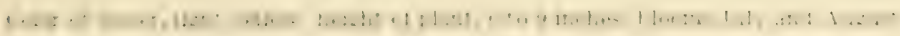

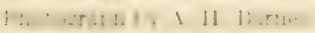

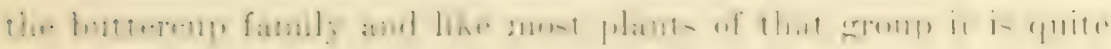
ornamental. Many questions are asked about it

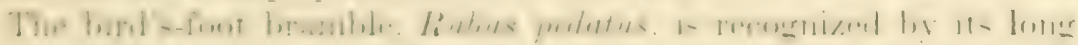

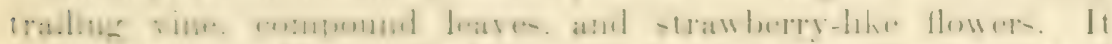

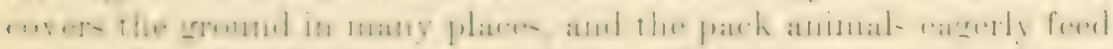

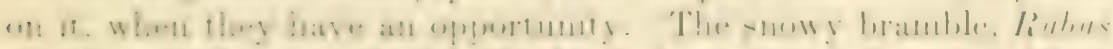

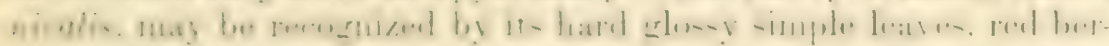
ries. and red flowers. It is never found in such abundance ats the above. Somewhat similar to the birl's-fout brannhle is Rubus lasiu.

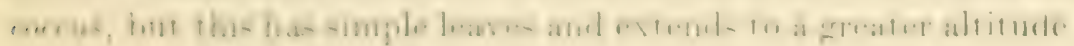


Along the rivers where there is an abundance of light may be found a strange assembly of plants. Many are washed down from above and have rooted in the scanty soil. Those not adapted will sooner or later die, while those like the alder and willow form thickets and grow luxuriantly, thus giving protection to other plants. In this way the river channel is often changed. Luina hypoleuca, a beautiful composite plant with glossy oval leaves, white underneath, is found on the old river channels at Longmire Springs and much lower down. This grows on the perpendicular cliffs near the glaciers. The plants themselves may be washed down and take root when stranded, or seeds may be carried by the river and lodge on the gravel bars and germinate, producing the species at a lower altitude. Perhaps both methods are successful in the production of these river bottom strangers, many of which compete successfully with those plants common to that region. Maples, cottonwoods, alders, and willows are the arborescent plants usually found here. These river-bar waifs are usually those which grow along streams higher up or on perpendicular cliffs above the streams.

There are several extensive areas swept by fire just below the meadows. The "pearly everlasting" seems to have taken possession of some of these, while the fireweed and a combination of other plants have a firm hold on other areas. These burnt areas are strewn with fallen logs and old erect snags, which are tottering and ready to fall. After every windstorm there is a new addition to the prostrate forms. This is especially noticeable along the roads, trails, and telephone lines. Some of these aroas were burned 20 years ago. Still there is little progress toward reforestation. The areas near the forest receive the seed and new trees start up, while those more remote have made little headway and still present desolate scenes with their blighted erop of "ghost trees" and scattered logs. The huckleberries, mountain ash, and the white rhododendron usually grow in great profusion and ripen their fruit in excellent condition.

\section{THE THIRD ZONE.}

The lower part of the third zone or the first meadows reached are usually moist and covered with tall grasses and sedges. The sedges are more abundant and can be recognized by their triangular stems and coarse appearance. In the early part of the season these grassy places are covered with a minute form of a swamp riolet. This grows so near the ground that it is often overlooked.

The shooting star, Dodecatheon jeffreyi (fig. 15), is one of the most conspicuous. It has a rosette of oblanceolate leaves and peculiar shaped flowers, resembling those of the cyclamen, which is a near relative. 


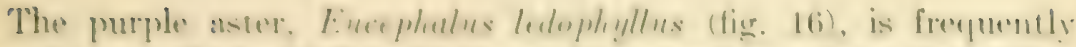
found here. It has tall leafy stems. leaves pubeserent on the molex-

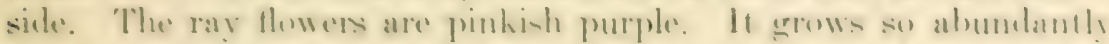

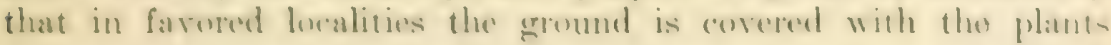

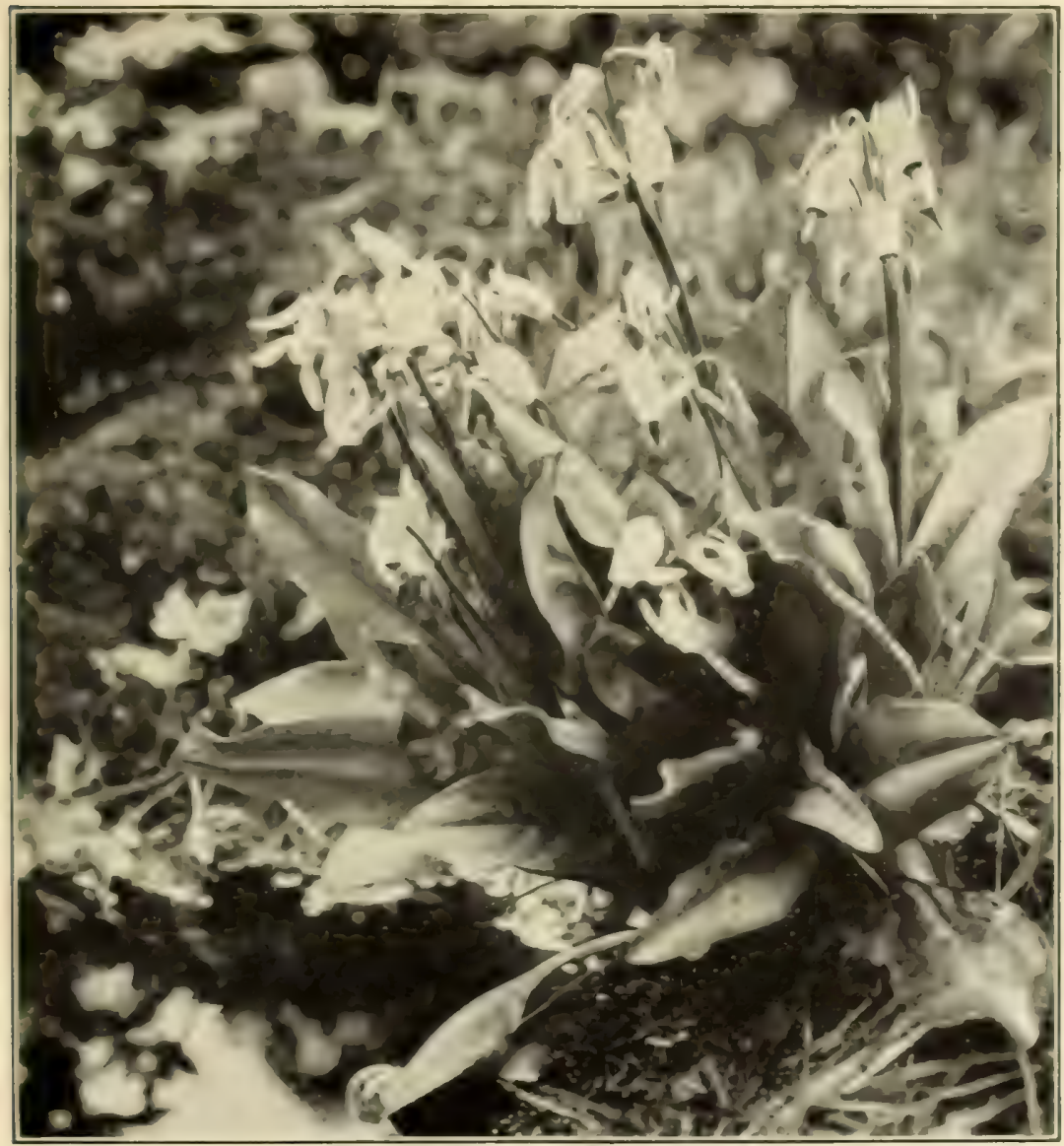

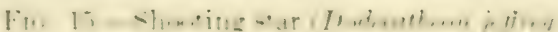

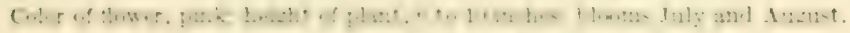

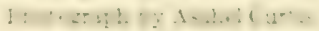

with heal tourhing heat, swaying in unimen to the least breath of wind.

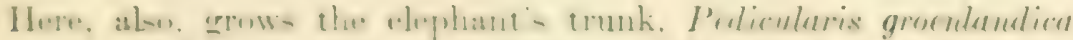

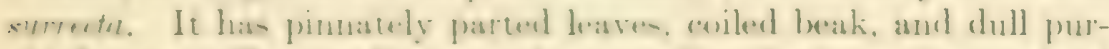

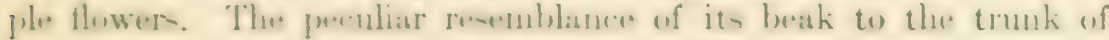

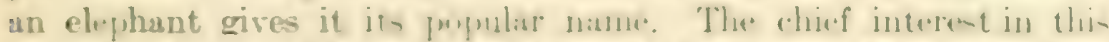

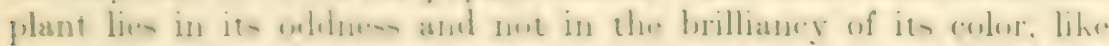

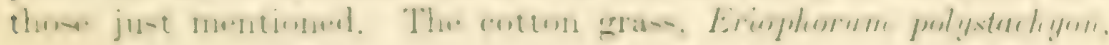


grows abundantly here, with its long slender stalk, bearing a white cotton-like tuft on the summit. Sometimes this plant seems to take complete control of small areas, but more of ten grows mixed with other plants. The rosy spiraea, Spiraea densiflora, is a wellknown little shrub bearing dense clusters of small red flowers on numerous short slender stems. In similar situations in the Olympie

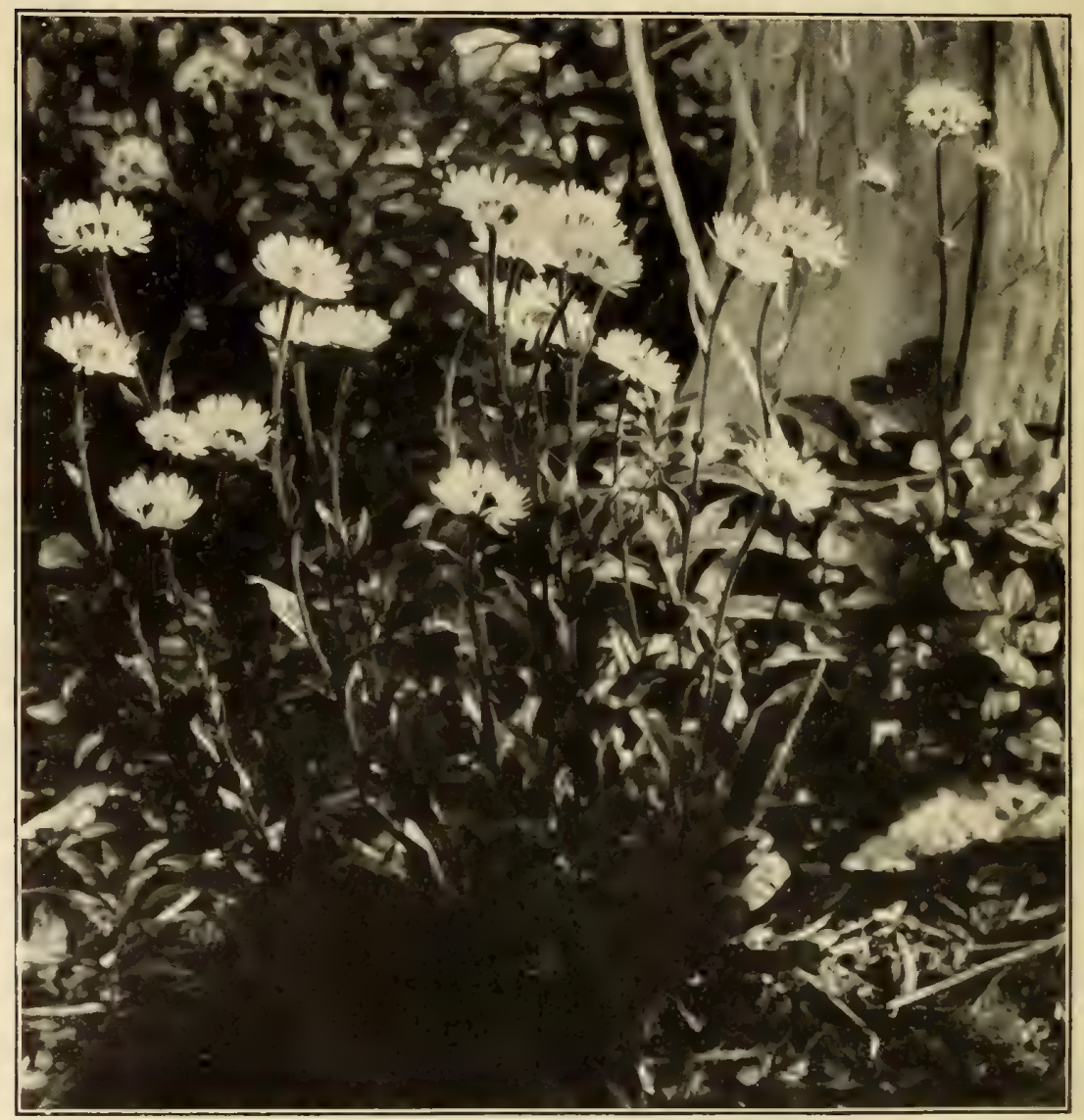

Fig. 16.-Purple aster (Eucephalus ledophyllus).

Color of flower, pinkish purple; height of plant, 1 to 2 feet; blooms July to September. Photograph by Asahel Curtis.

Mountains the Douglas spiraea of the lowlands grows with the above, but this combination has not been seen here. Salix commutata, the common alpine willow, grows abundantly in these low meadows and bogs, and is in bloom about the 1st of Juty. There are few plants in bloom on the mountain before that time, unless the season should be unusually early. Leptarrhena, Saxifraga, Mitella, and Erythronium are some of the other genera composing 


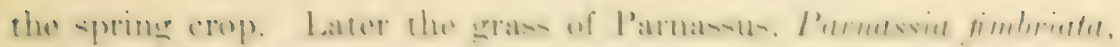

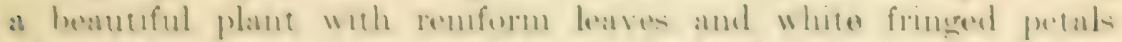

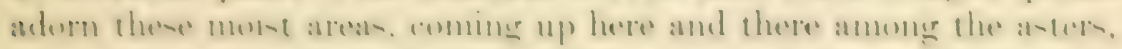

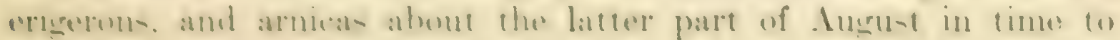
salute the last visitors of the serson.

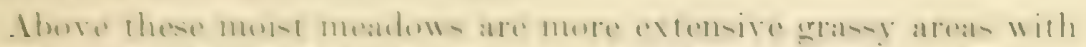

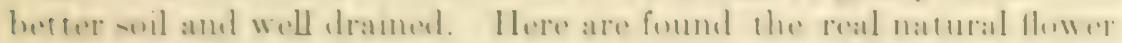

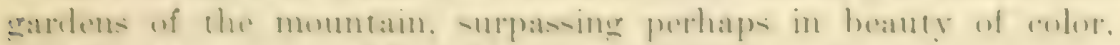

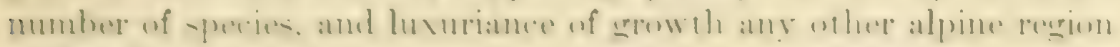
of the world.

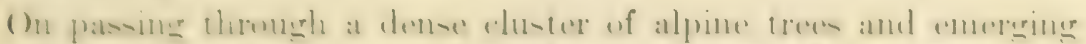

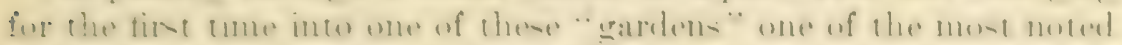

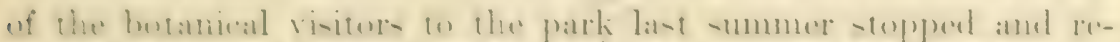

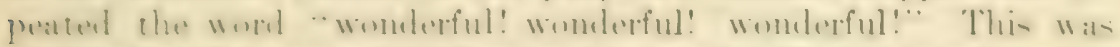

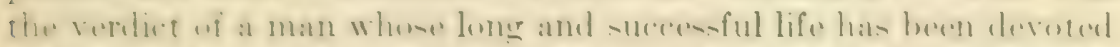

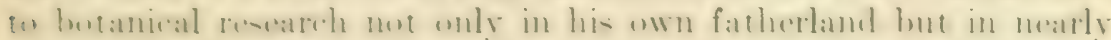

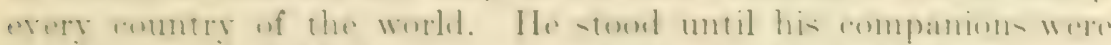

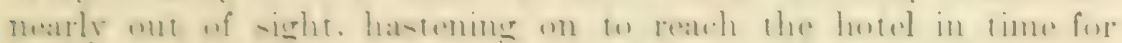

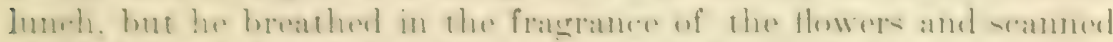

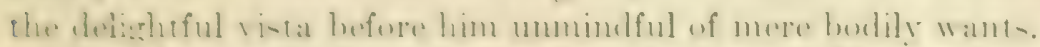

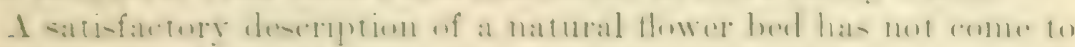

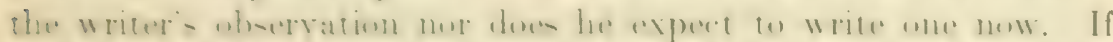

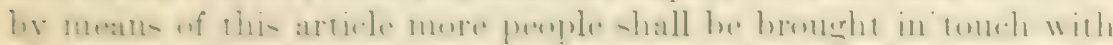

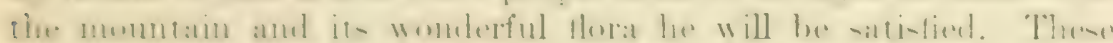

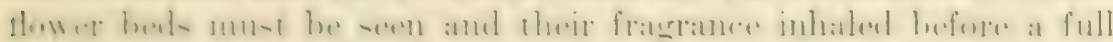

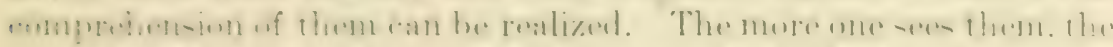

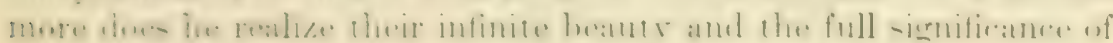
the spiritual lesons which these floral emblems teach.

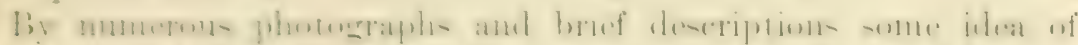

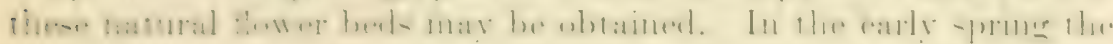
whice nountain decrongue, Erythonium montamum (fig. 17), is

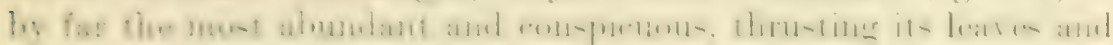

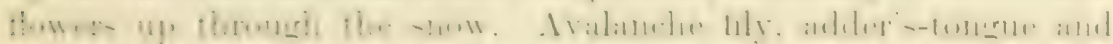

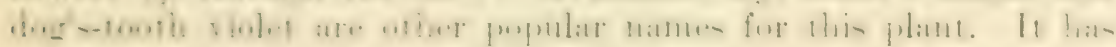

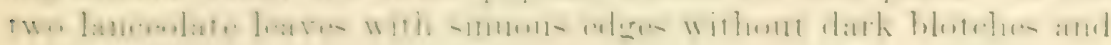
serveral thewers in the forme of a raceme.

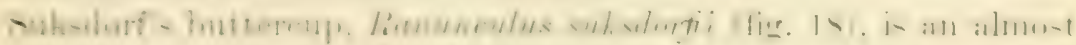

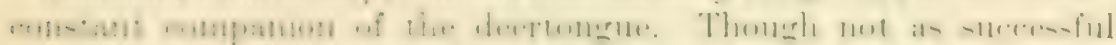

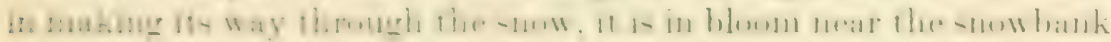
ans af wer the -

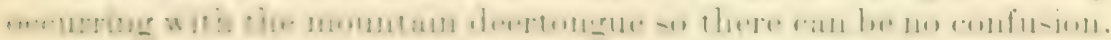

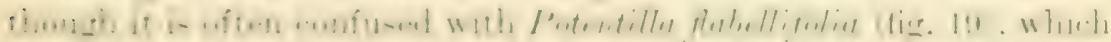

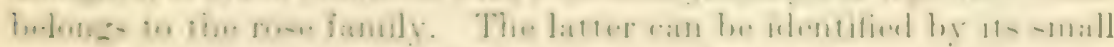

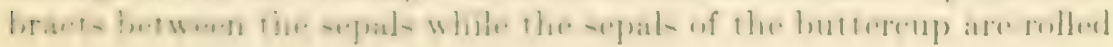


back and fall off early. The potentilla is also larger than the buttercup and does not bloom so near the snow.

The western anemone or Pulsatilla occidentalis (figs. 20 and 21) is also ready to put forth its blossoms with the buttercup. This is the only anemone found near the snow. It has large lavender flowers with leares still in the bud until the floral organs drop off. Then the finely dissected leaves unfold and the plumelike heads de-

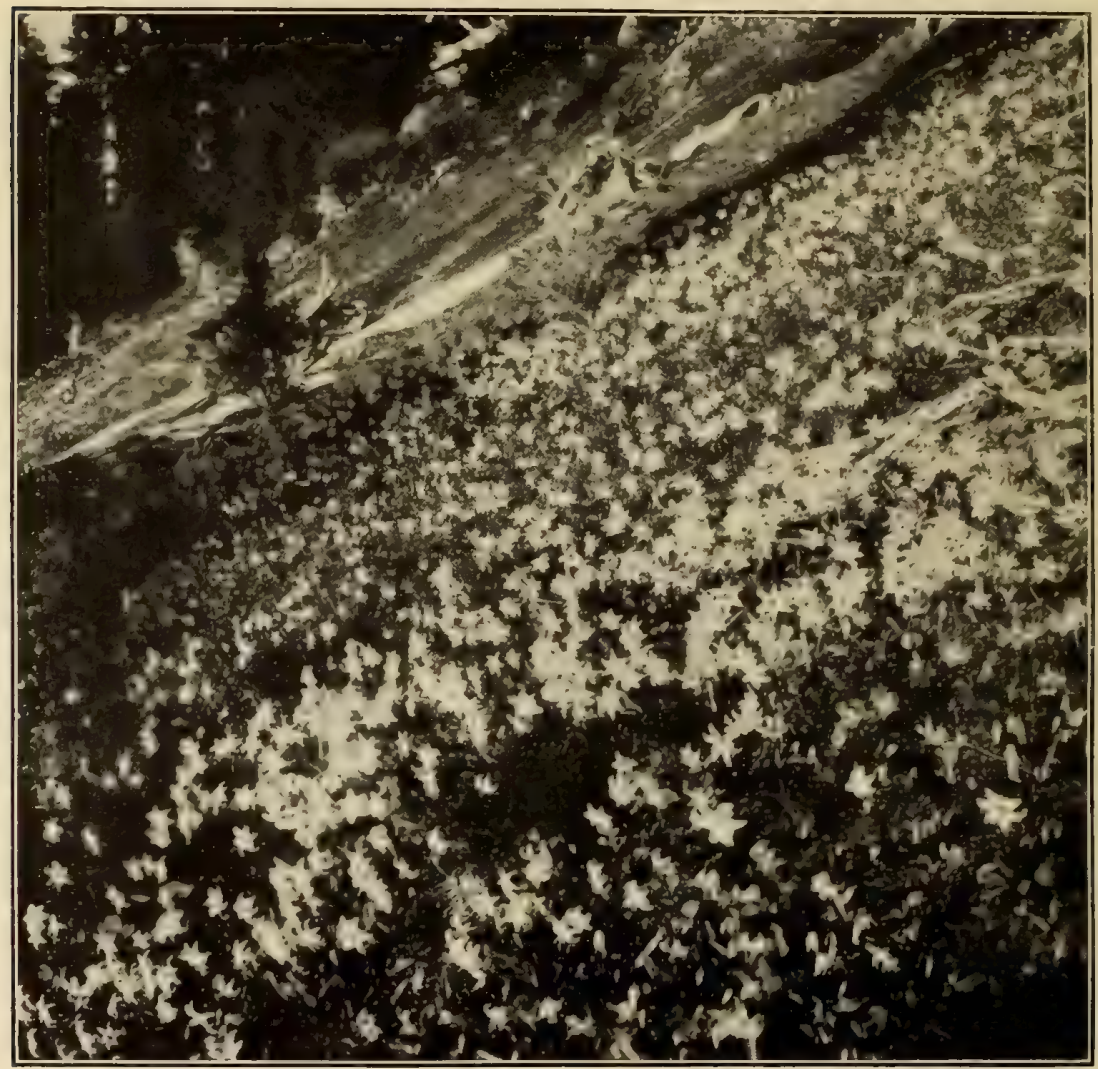

FIG. 17.-Deer tongue (Erythronium montanum).

Color of flower, white; height of plant, 7 to 15 inches; blooms July and August. Photograph by Asahel Curtis.

velop, showing the feathery appendages of the seeds. It is greatly admired both in flower and fruit.

$\Lambda$ ter these hardy pioneers have held undisputed sway for a week or two the other plants spring forth in rapid succession transforming the bare ground and the site of the dust-covered snow bank into a veritable flower bed. The season is short. Everything moves rapidly. As the weeks come and go so does the succession of plants 


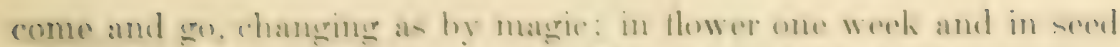
the next. The most con-piemose of the later plants is the valerian.

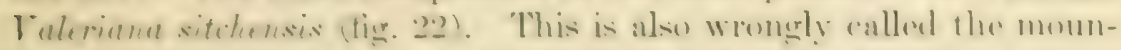
tain heliotrope on aceount of its small pinki-h white flowers in cymen. resemblung the common gavelen heliotrope thengh having me rolattionship. It is a tall plant with a strong charateteristive onler: the leares are pinnate, the upper leatlet being he far the largest. It is usintly one of the talle-t plant in thene flower beds in the neighther-

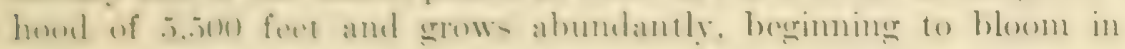

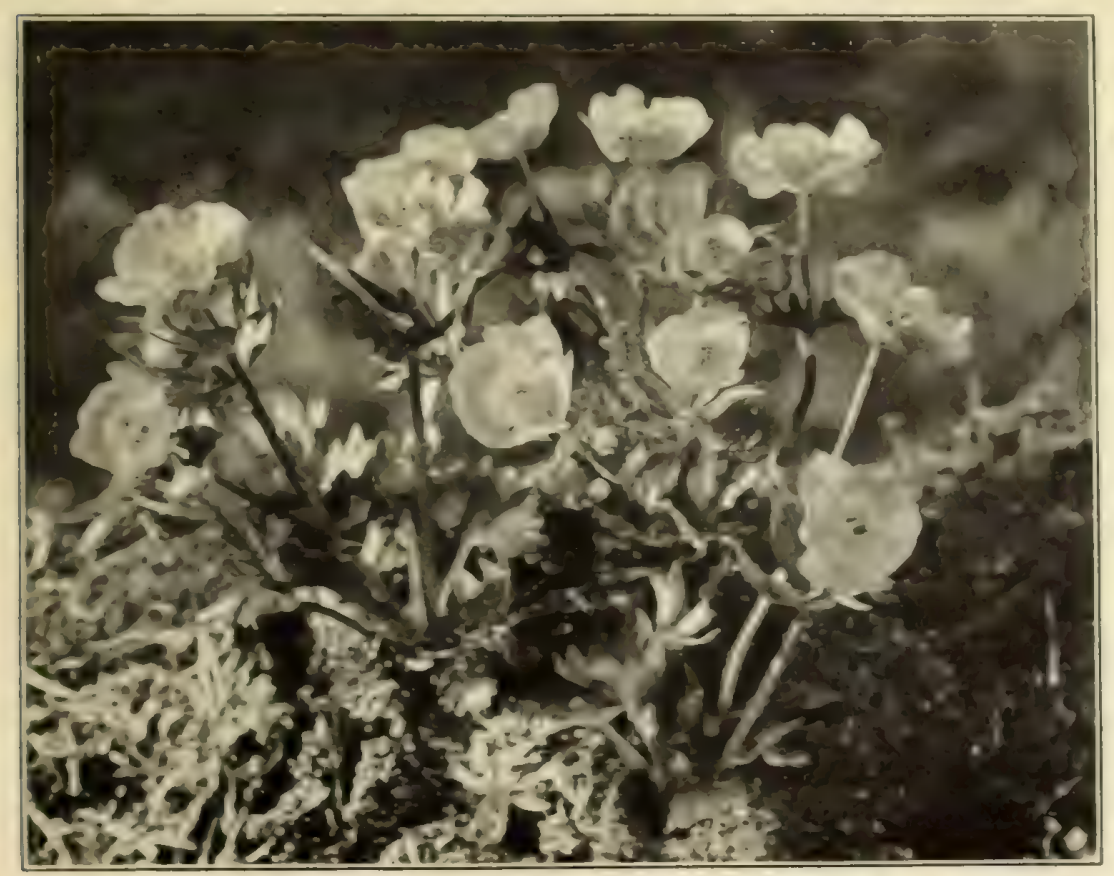

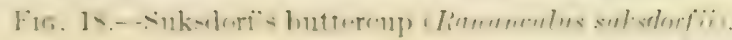

Cinlor of tlower, yellow; height of plant, 5 to 12 inches; blooms July and August.

Photompin by A. H. Barnt

the early part of July. It continuse- 10 hewem until the middle of August or the first of September.

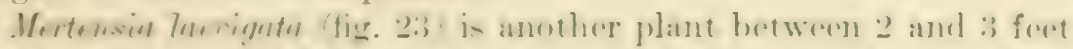
hich with racene of blue-purple flewers and thin orate leares. The

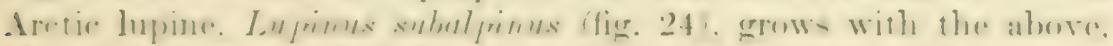

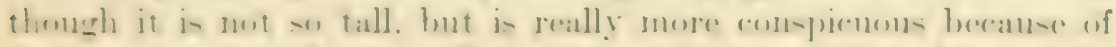

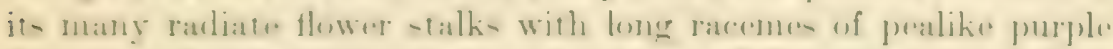

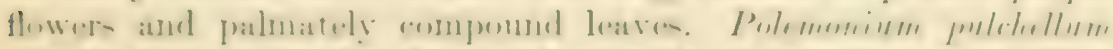

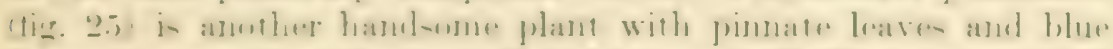

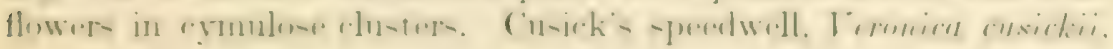


is a small plant about 3 to 6 inches high with opposite ovate leaves and raceme of blue-violet flowers. It is a very abundant plant at an altitude of about 5,000 to 6,000 feet on all sides of the mountain. What it lacks in size it makes up in abundance and does

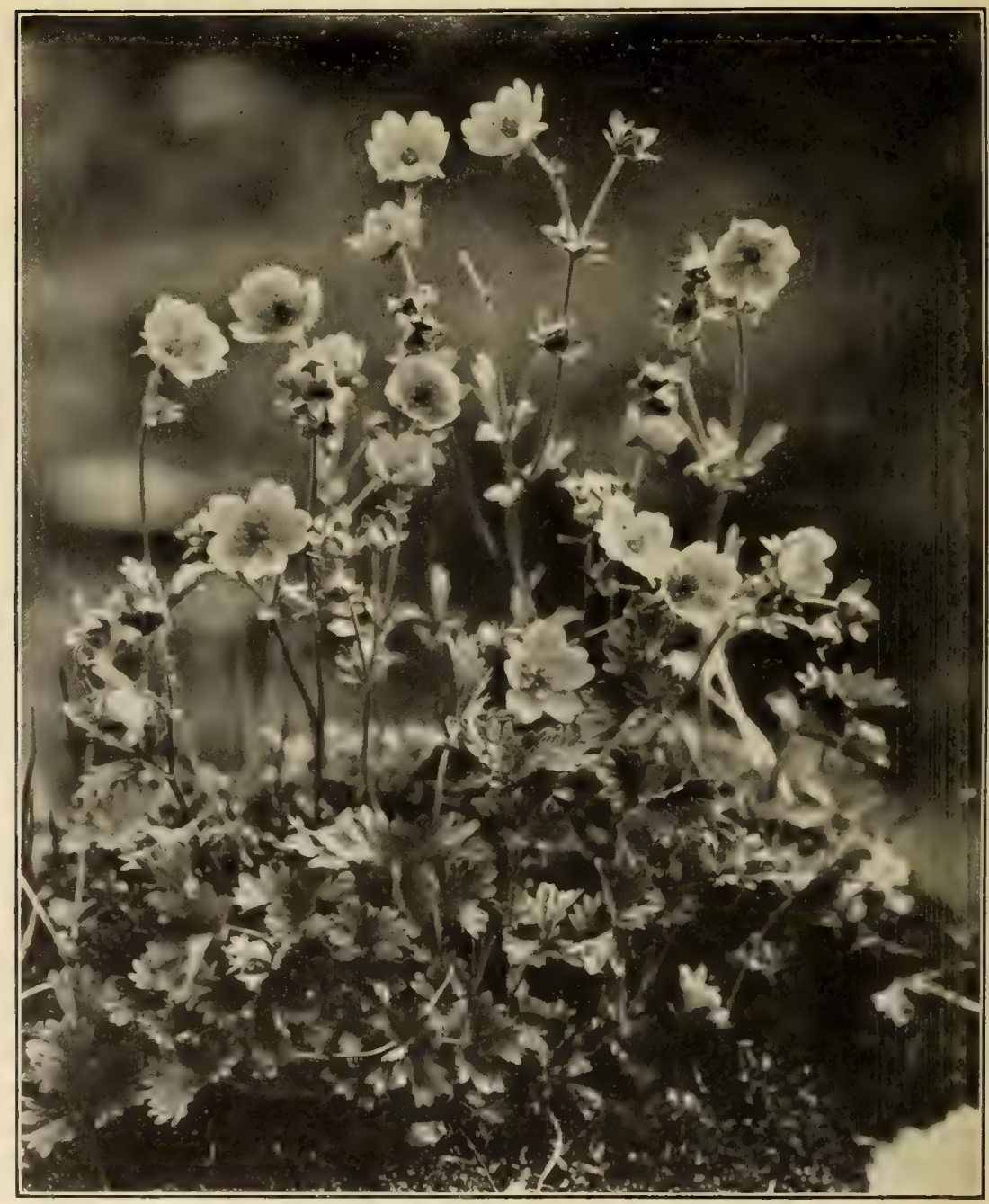

FIG. 19.-Potentilla fabellifolia

Color of flower, yellow; height of plant, 8 to 16 inches; blooms July and August. Photograph by A. H. Barnes.

much underneath the mertensias, lupines, and polemoniums to render prominent the blue color in the flower beds. The Indian paint brush, Castilleia oreopola, attracts more attention, perhaps, than any other plant of its size on the mountain, because of its bright 


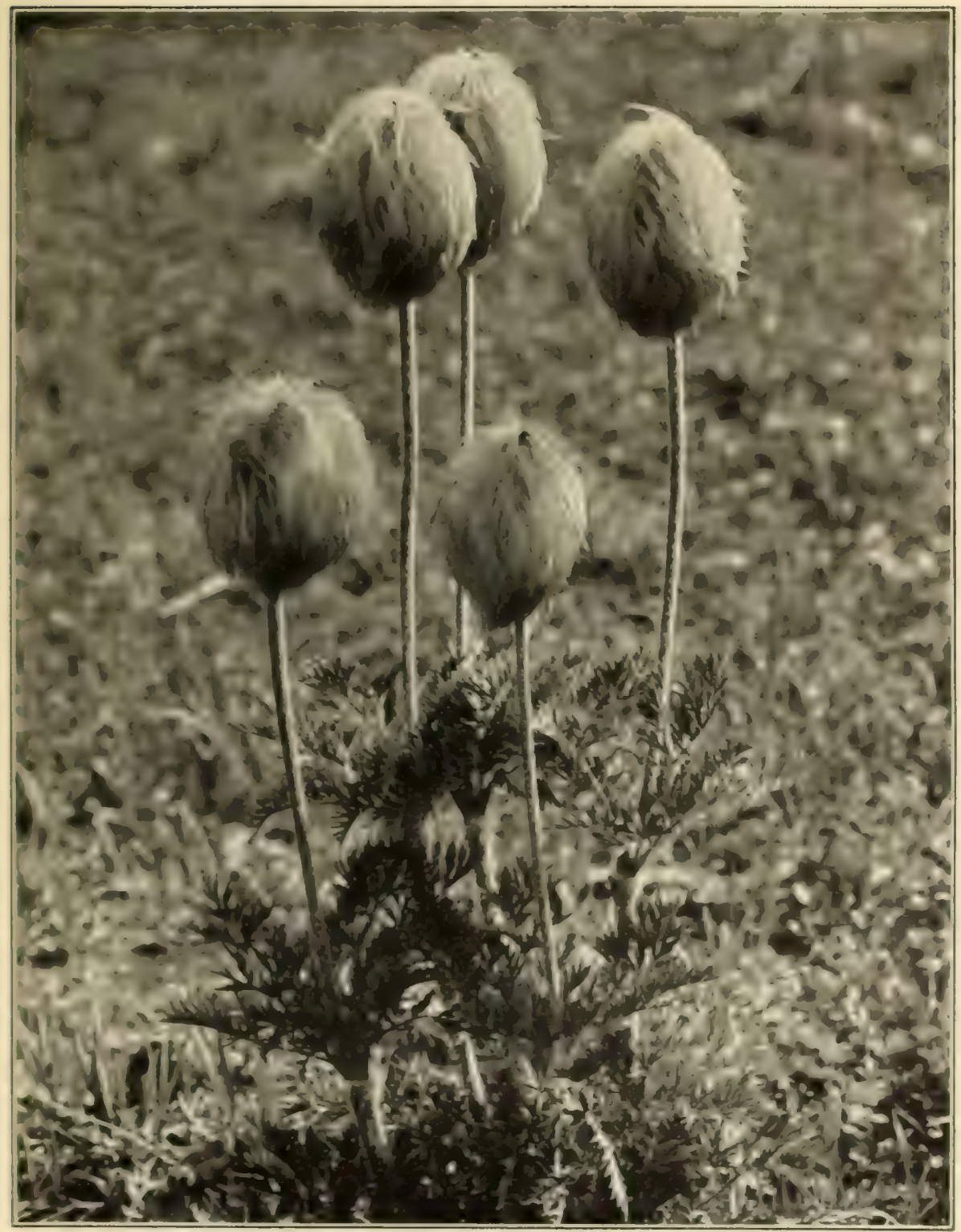

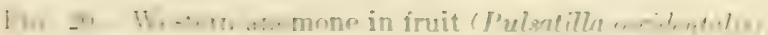

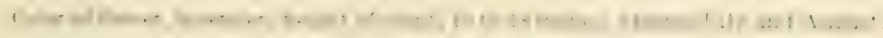


red or purplish red color and radiate clusters. These red clusters appear in well-balanced groups throughout these extensive flower beds, harmonizing with the blue, the white, and the yellow of other plants. Painted cup is another popular name for it. These common names are applied to any species of Castilleia in this vicinity. The red heather forms dense patehes with its long shrubby stems usually leaning over to one side with its red bell-shape flowers.

Along the numerous streams may be found Lewis's monkey flower f20 with its rose-red two-lipped corolla. Here, too, may be seen

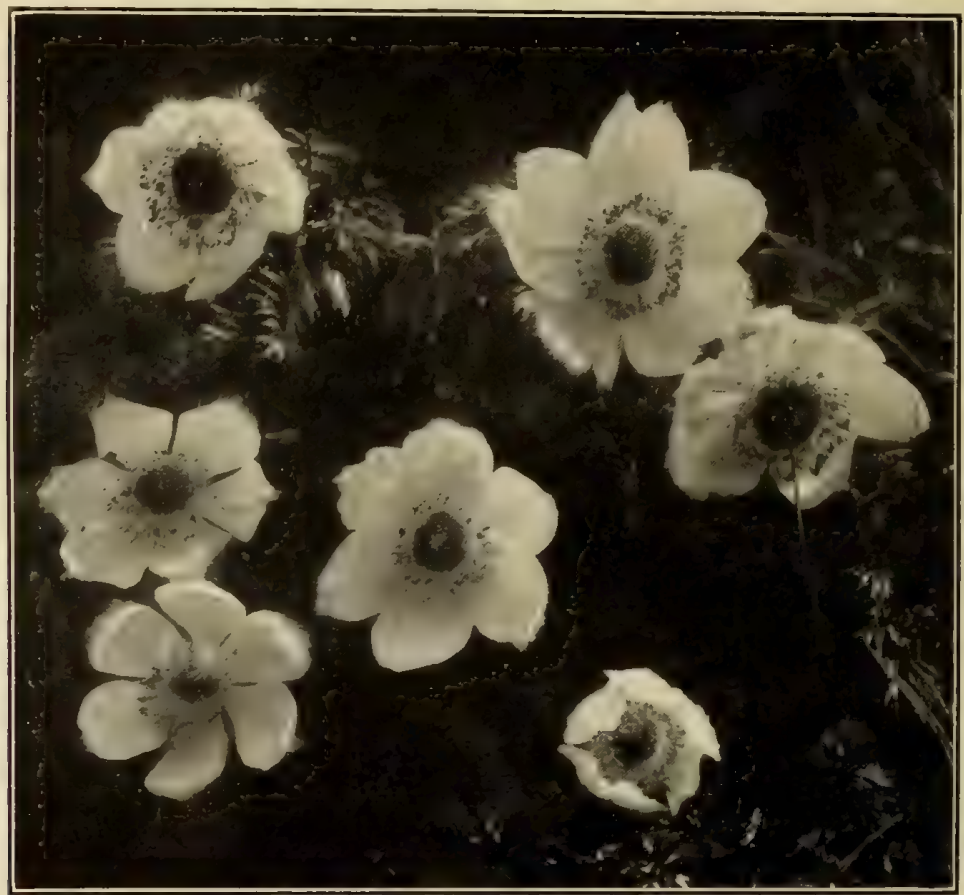

FIG. 21.-Western anemone in flower (Pulsatilla occidentalis).

Color of flower, lavender; height of plant, 10 to 18 inches; blooms July and August. Photograph by A. H. Barnes.

the rosy spiraea which continues up from the lower moist meadows. The spiraea and the monkey flower are always associated with moisture, while the Indian paint brush and red heather are not. These rills can often be traced in the distance by the bright rose-red flowers of Lewis's monkey flower and by the bright yellow of the alpine monkey flower. "which' loves the same habitat. Both species grow in dense masses and often cover the ground to the exclusion of other plants. The yellow fireweed, Epitobium luteum, flourishes best along the streams in the lower meadows. It may be known by its 


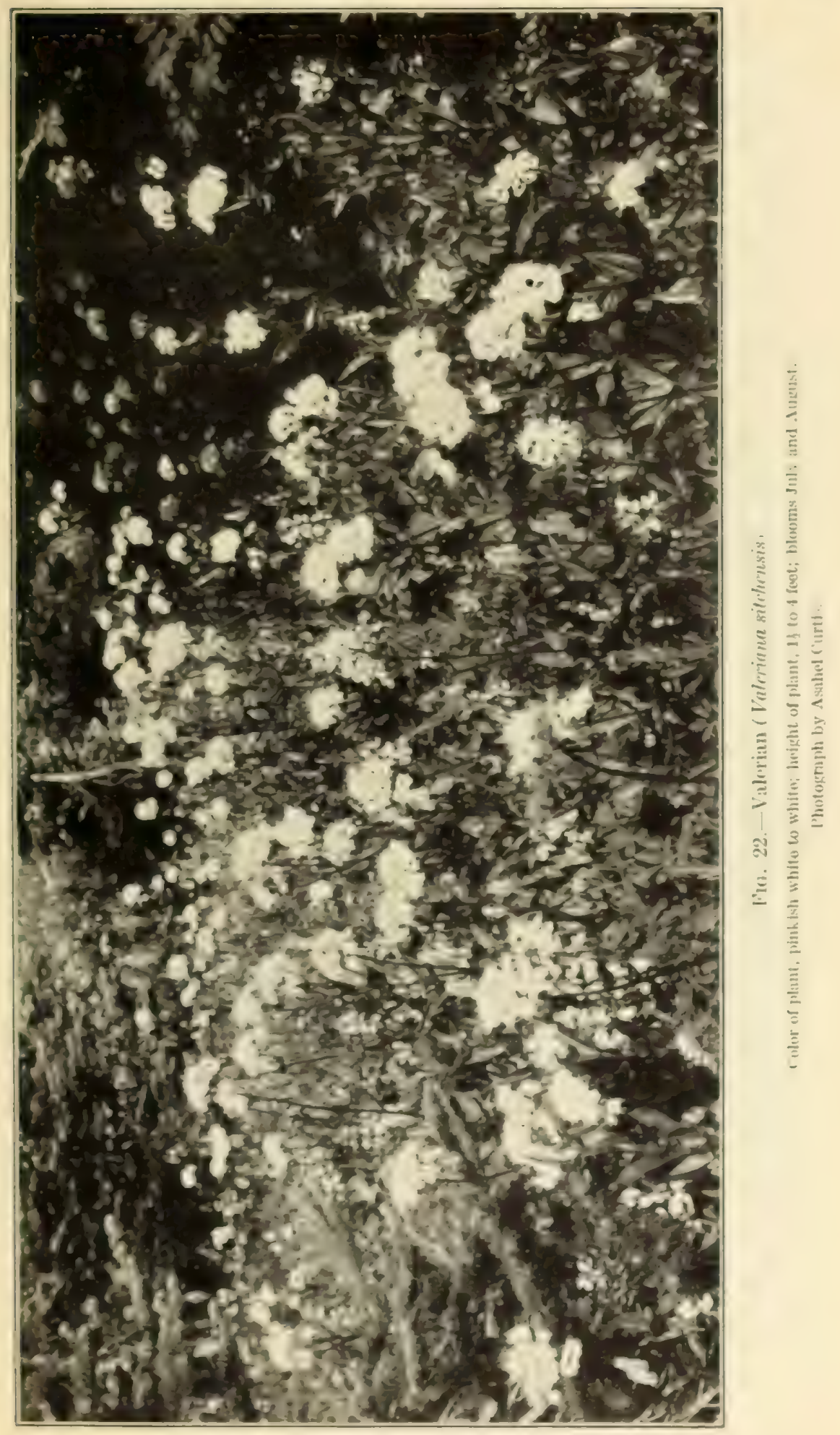


creamy yellow flowers and ovate to lanceolate opposite leaves on a rather tall stem.

The mountain dock, Polygonum bistortoides (fig. 27), may be known by its lanceolate radical leares and rather long, slender stem, hearing an oblong spike of small white flowers. This plant is very abundant

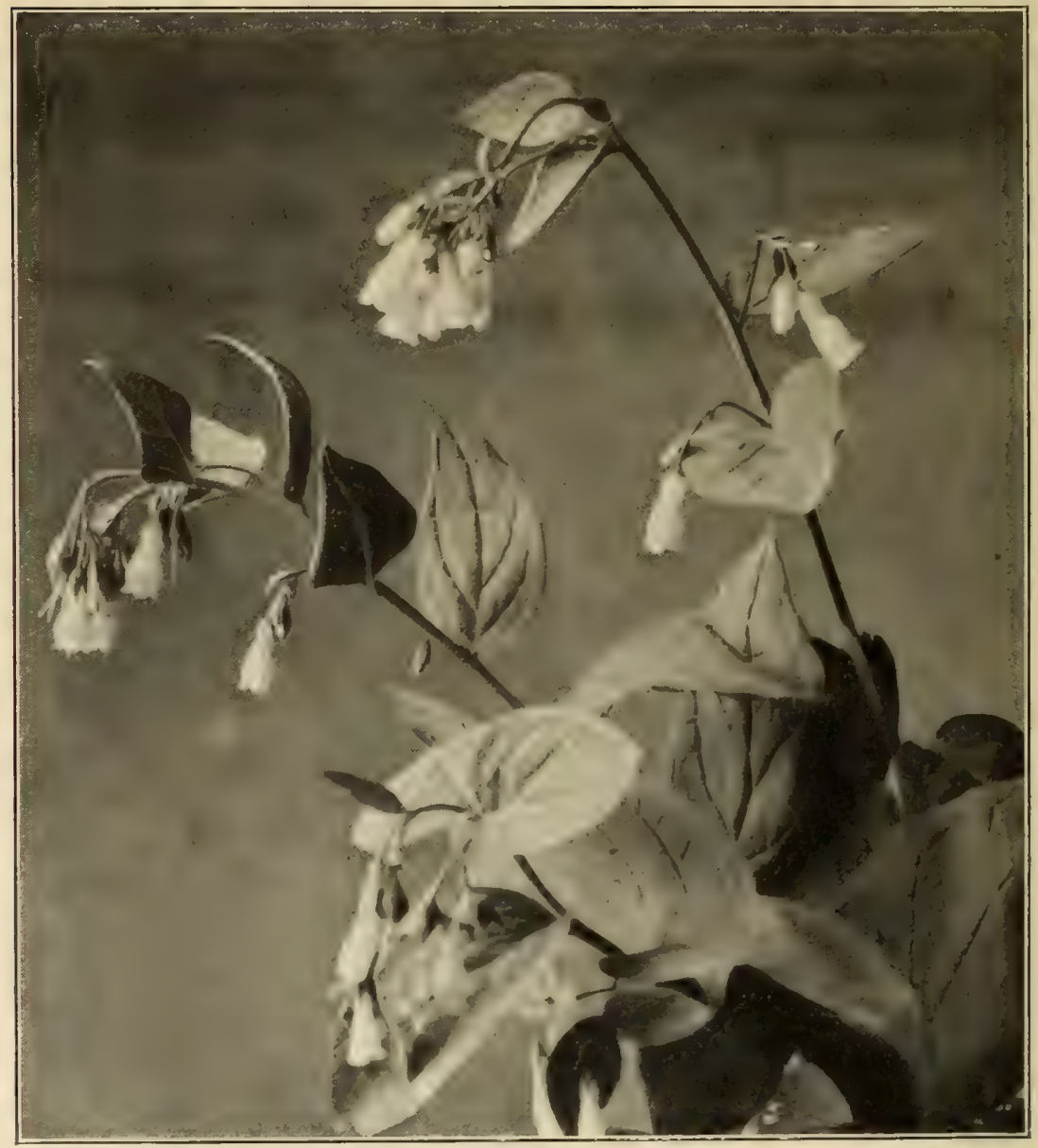

F'IG. 23.- Mertensia laevigata

Color of tlower, blue to pinkish blue; height of plant, 2 feet; blooms July and August. Photograph by A. H. Barnes.

and is easily swayed about by the wind, thus trying the patience of the flower photographer. It is nearly always associated with the valerian and the asters. There are several plants of the parsley family which may be recognized by their umbels of white or purplishwhite flowers. The "wild parsnip," Ligusticum purpureum, has finely dissected laves and small whitish purple flowers. The mountain ash, 


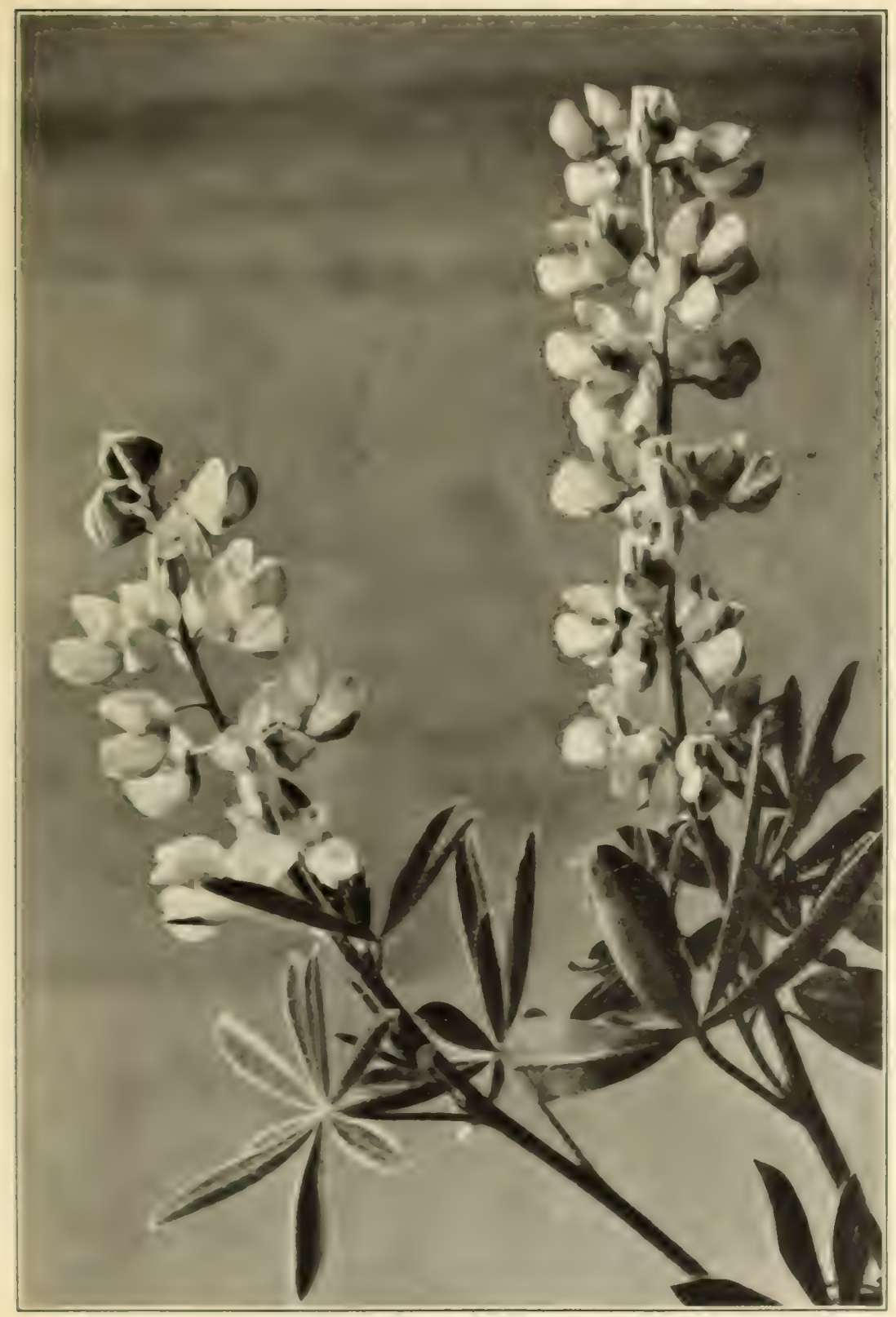

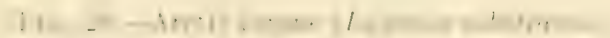

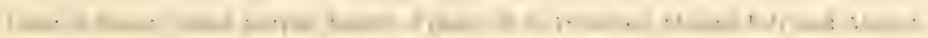




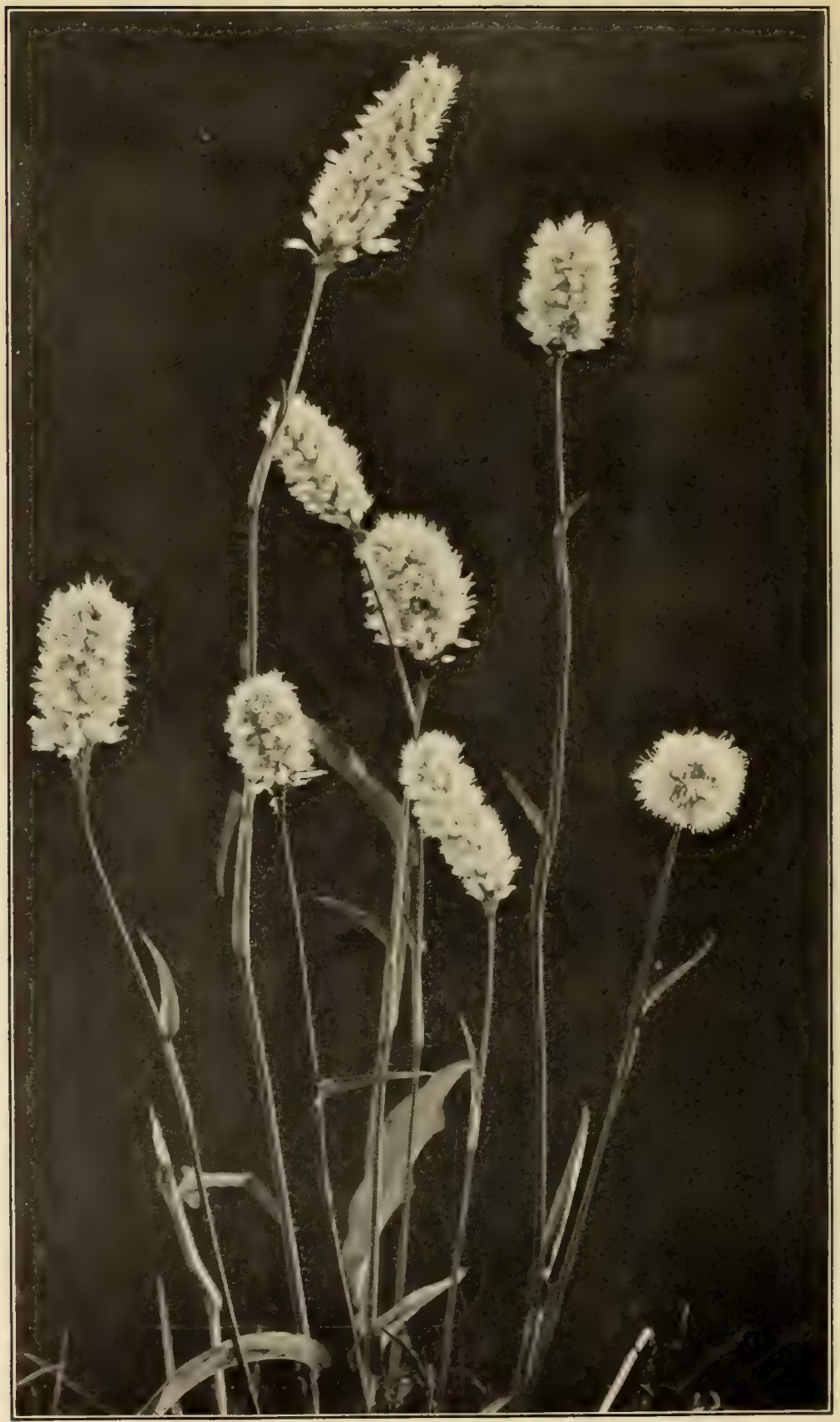

FIG. 27.-Mountain dock (Polygonum bistortoides).

Color of flower, white; height of plant, 1 to 2 feet; blooms July and A ugust. Photograph by A. H. Barnes. 


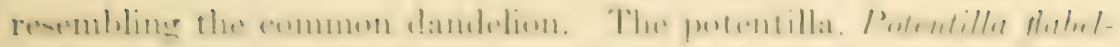

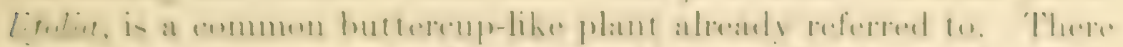

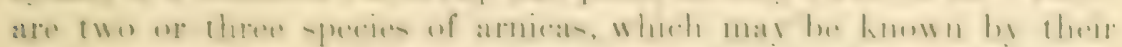

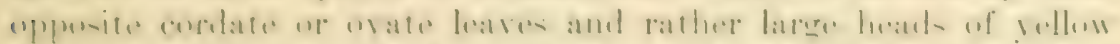

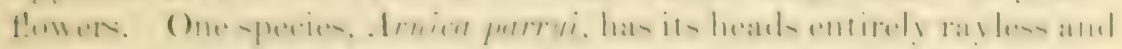

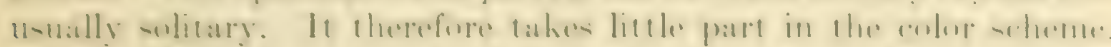

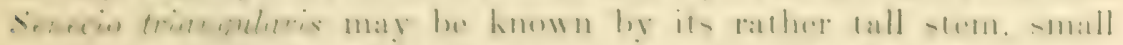

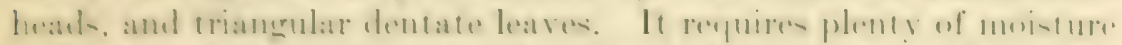

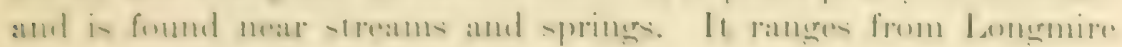
springs to the "Camp of the Clouds."

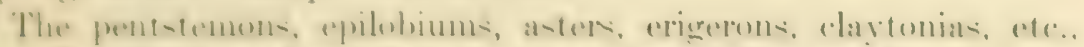
contribute pinh and purple in ever varging shates. mahing the hatrmony complete.

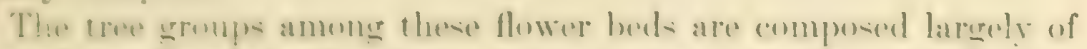

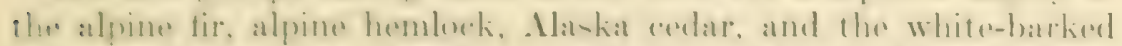

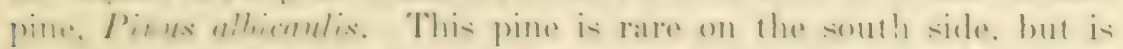

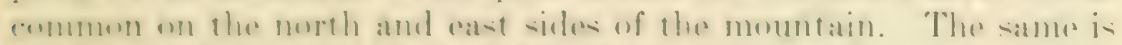
true of an alpine form of the tideland spruese. These trese are peretliar in that their trunke ries up like spires white their shert branehes are hent dewnward by the weicht of the snew. In the fieresestrugerde for evistence their wout has been strengthened to a remarkable

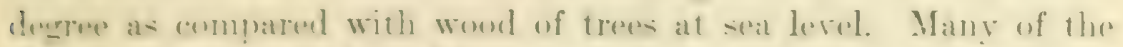

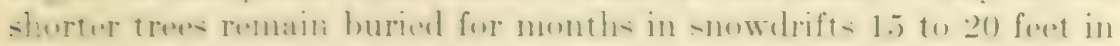

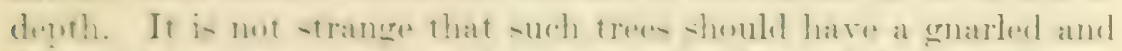

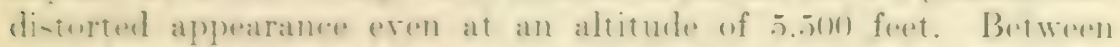
this altitude and 6.jon foet there is a marked chamere to smaller

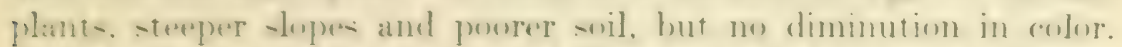
In fart. the colur atheme is inten-ified, and many of the mo-t beantiful flower beds are found about 6,000 feet or a little abore.

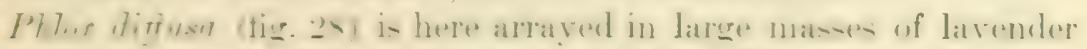

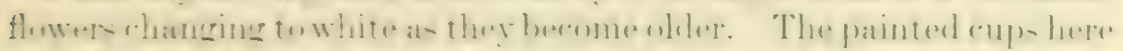

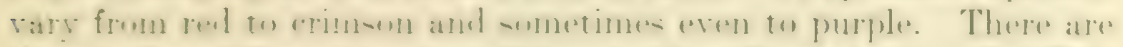

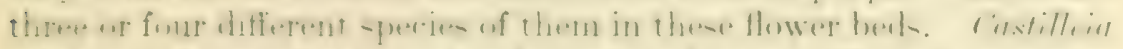

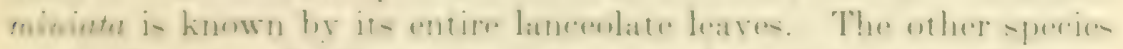

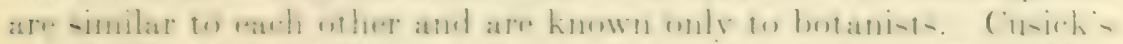

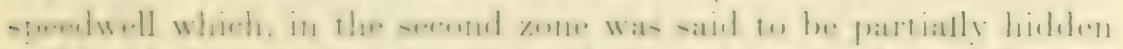

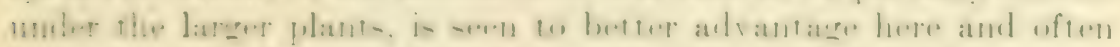

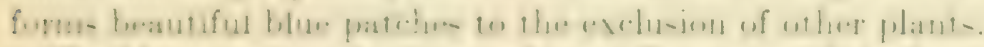

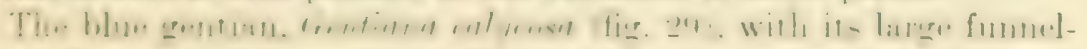

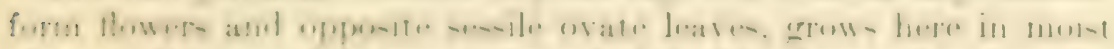

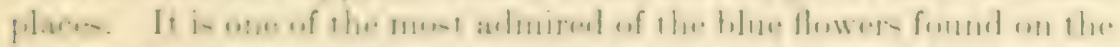

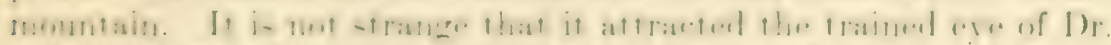

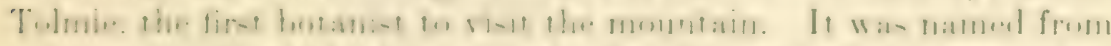

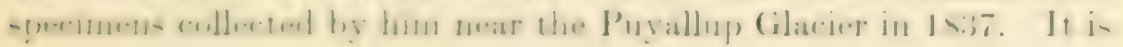


abundant at the end of the trail leading into Van Trump Park and along the lower meadows on the glacier trail leading into Paradise Valley. It may be found from the lower meadows to timber line.

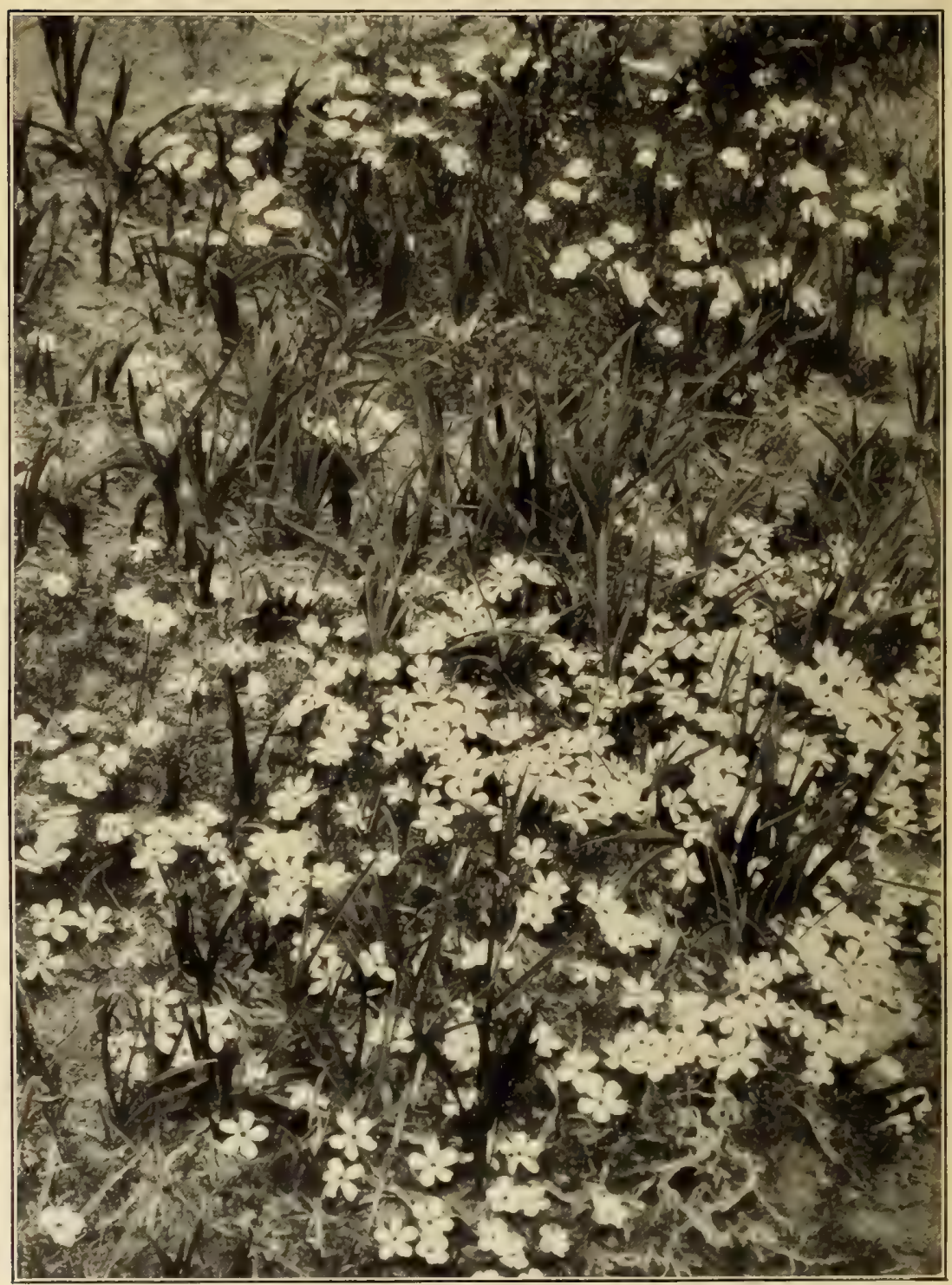

FIG. 28.-Mountain phlox (Phlox diffusa).

Color of flower, lavender to white; height of plant, I to 4 inches; blooms July and August.

I'hotograph by A. H. Barnes.

It blooms rather late, and may be found in October with its large, beautiful blue flowers up through a foot of snow, being held upright by small branches of the rosy spiraea or other shrubs common to 


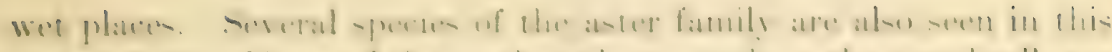

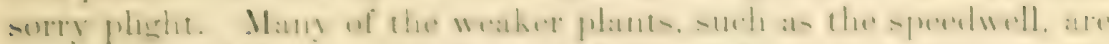

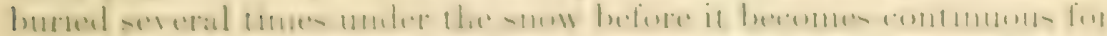

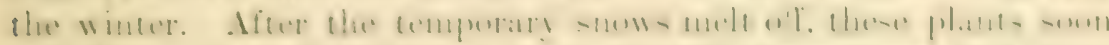

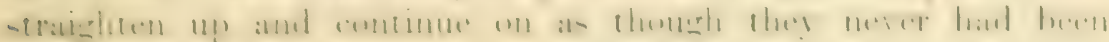
Inurienl.

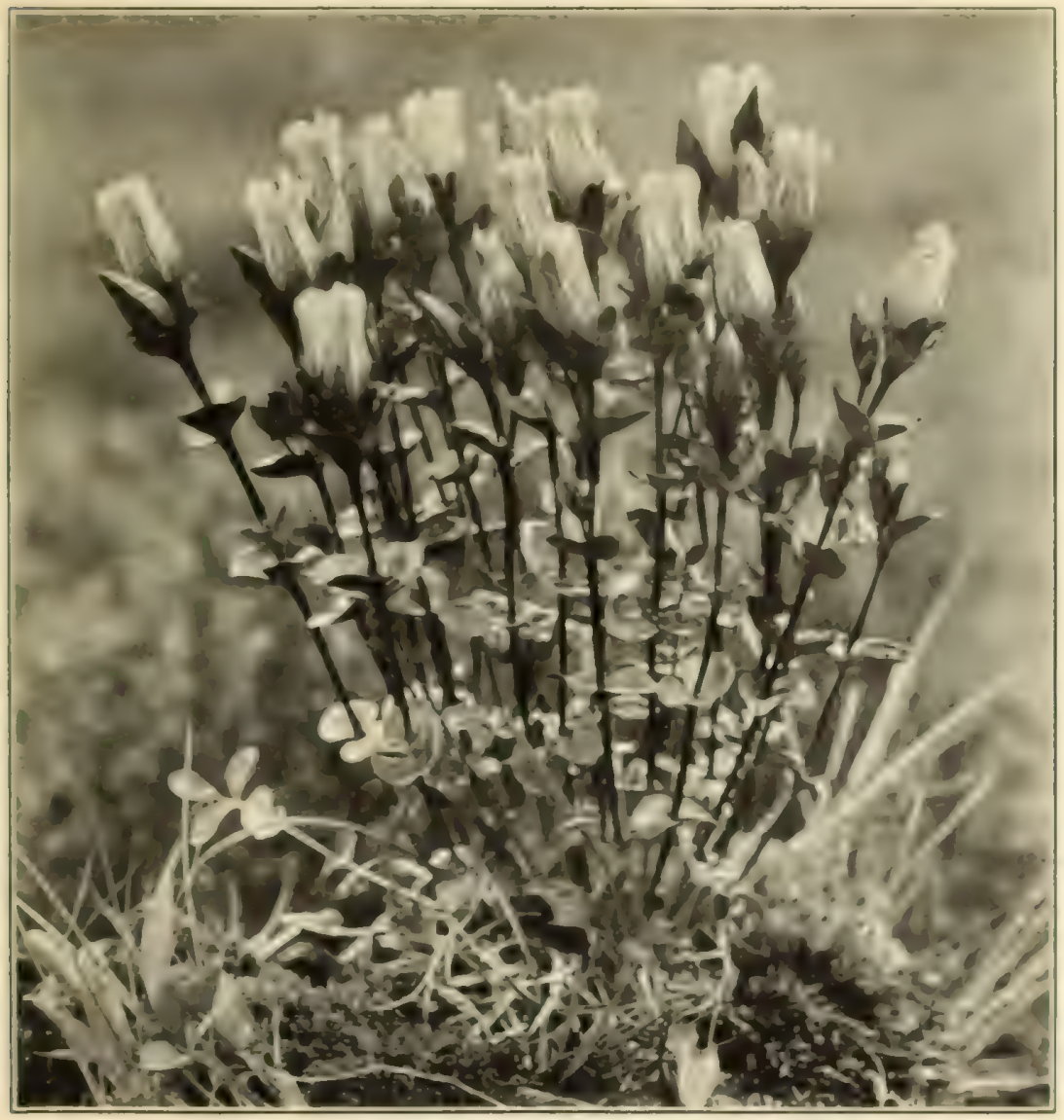

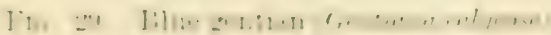

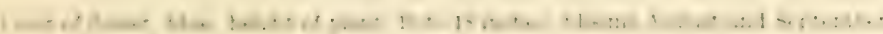

H..... \& $11:-$.

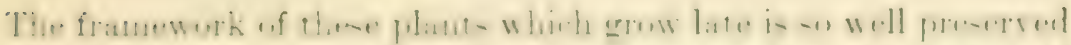

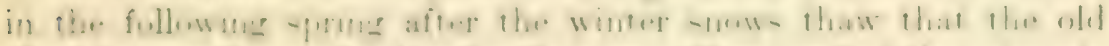

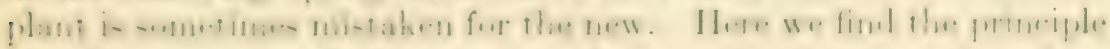

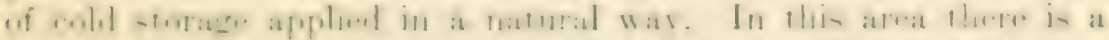

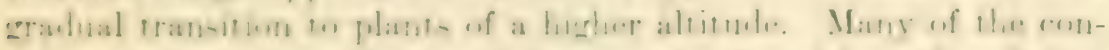

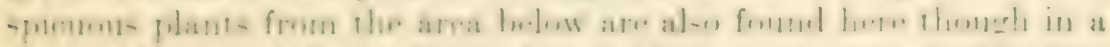

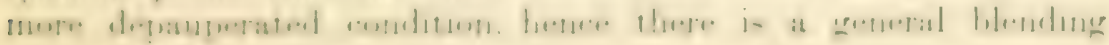


together of the high and low altitude trees. This transition area is, perhaps, the most interesting, because of the great rariety of plants and the infinite combinations found under different conditions of soil, moisture, and light.

The white and yellow deer-tongues, the arctic lupines, the valerians, and the polemoniums are abundant in the lower part of this region though not in the upper near 6,500 feet. Lupinus volcanicus is a characteristic timber-line plant all around the mountain. It differs

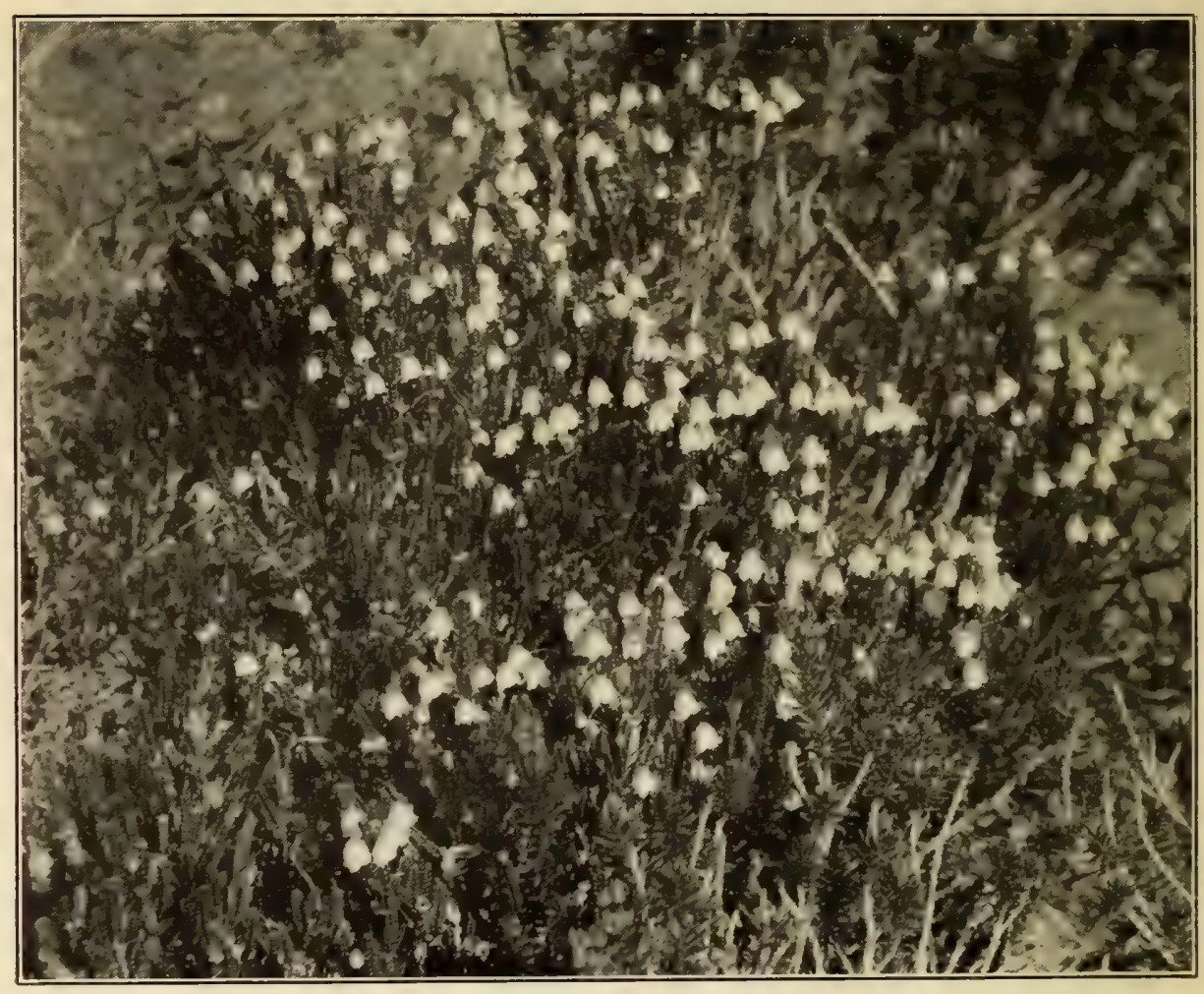

FIG. 30.-White heather (Cassiope mertensiana).

Color of flower, white; height of plant, 6 to 10 inches; blooms July and August. Photograph by A. H. Barnes.

from the plant in the lower meadows by its greater pubescence, coarser and shorter stems.

The white heather, Cassiope mertensiana (fig. 30), is one of the most attractive plants in the heather group. It is known by its bell-shaped, drooping flowers and rather short stems with small imbricated leaves. The red heather, Phyllodoce empetriformis (figs. 31 and 32), which is much more robust, often grows with it. It extends from 3,200 feet timber line. The yellow heather, Phyllodoce 


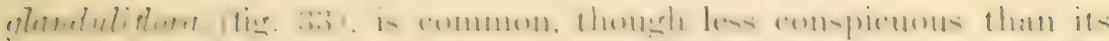

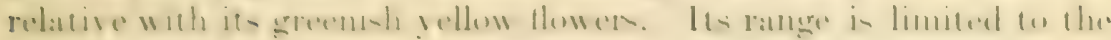
ricinity of timber line.

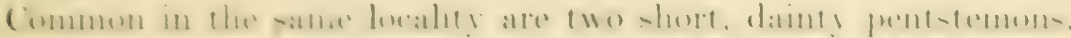

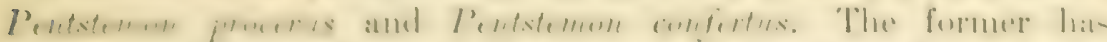

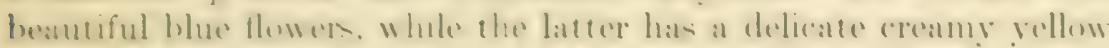

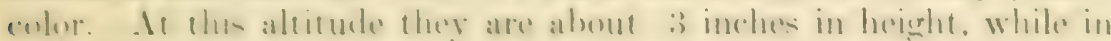

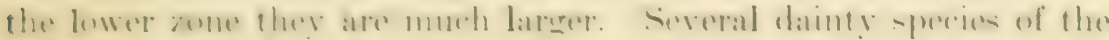

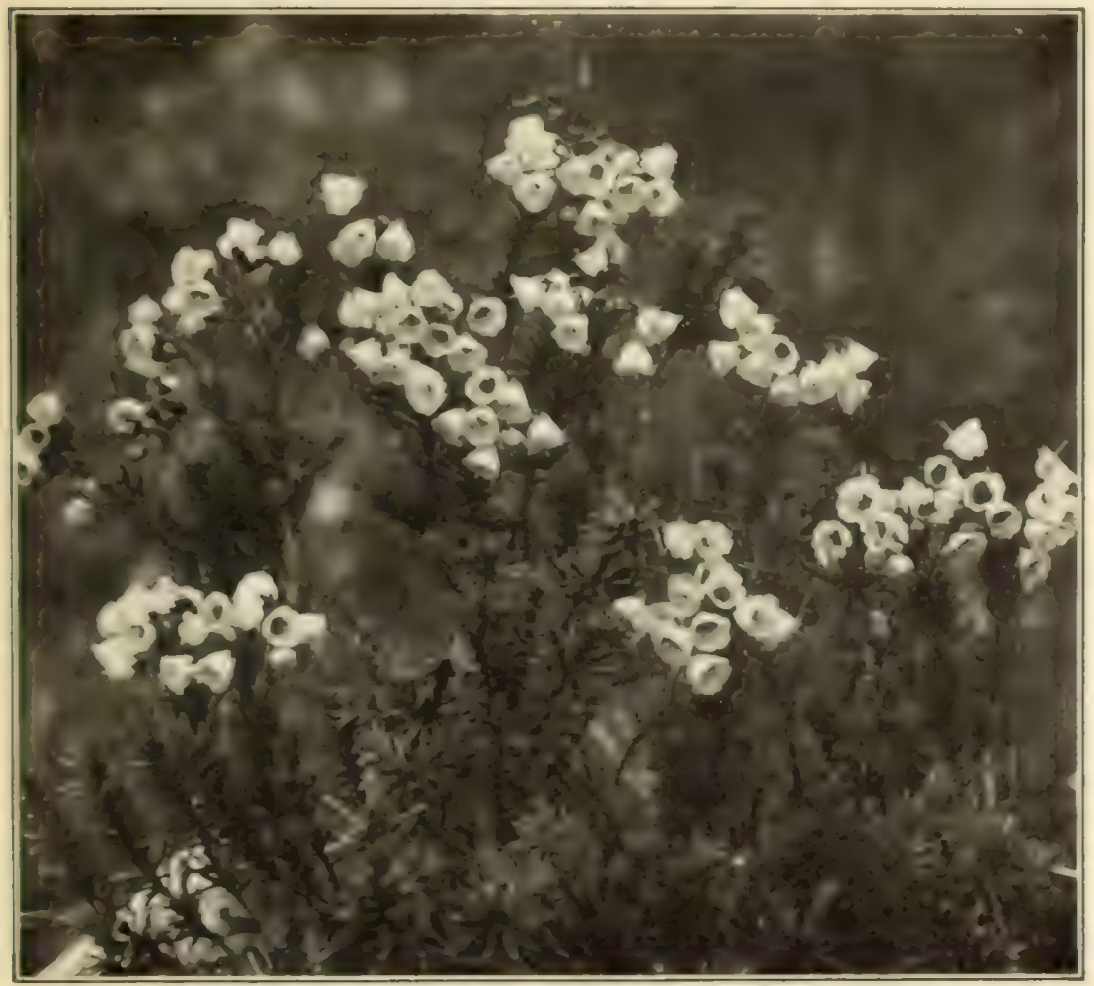

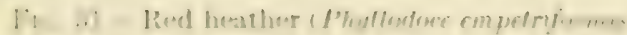

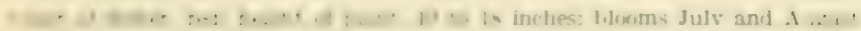

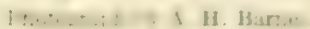

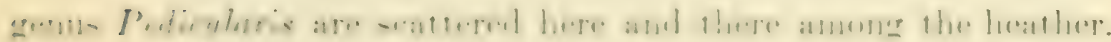

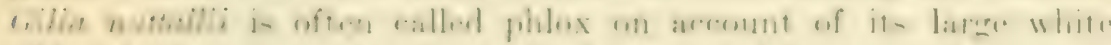

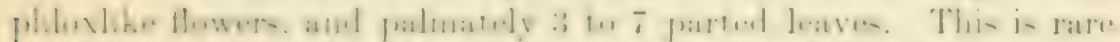

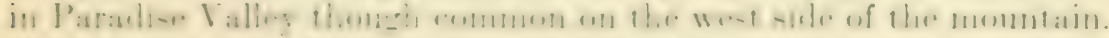

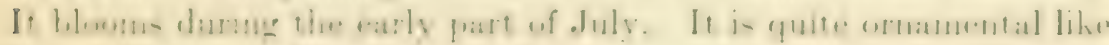
its relative the phlox. Which often is associated with it. The rills

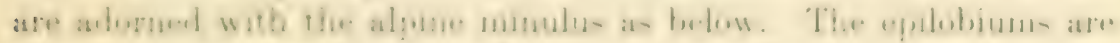
abundant. covering the ground with their small pink flow, r. 
Two cud weeds, Antennaria media and Antennaria lanata, are easily known by their white wooly appearance and rather short stems. The latter is larger with denser heads and narrower leares than the

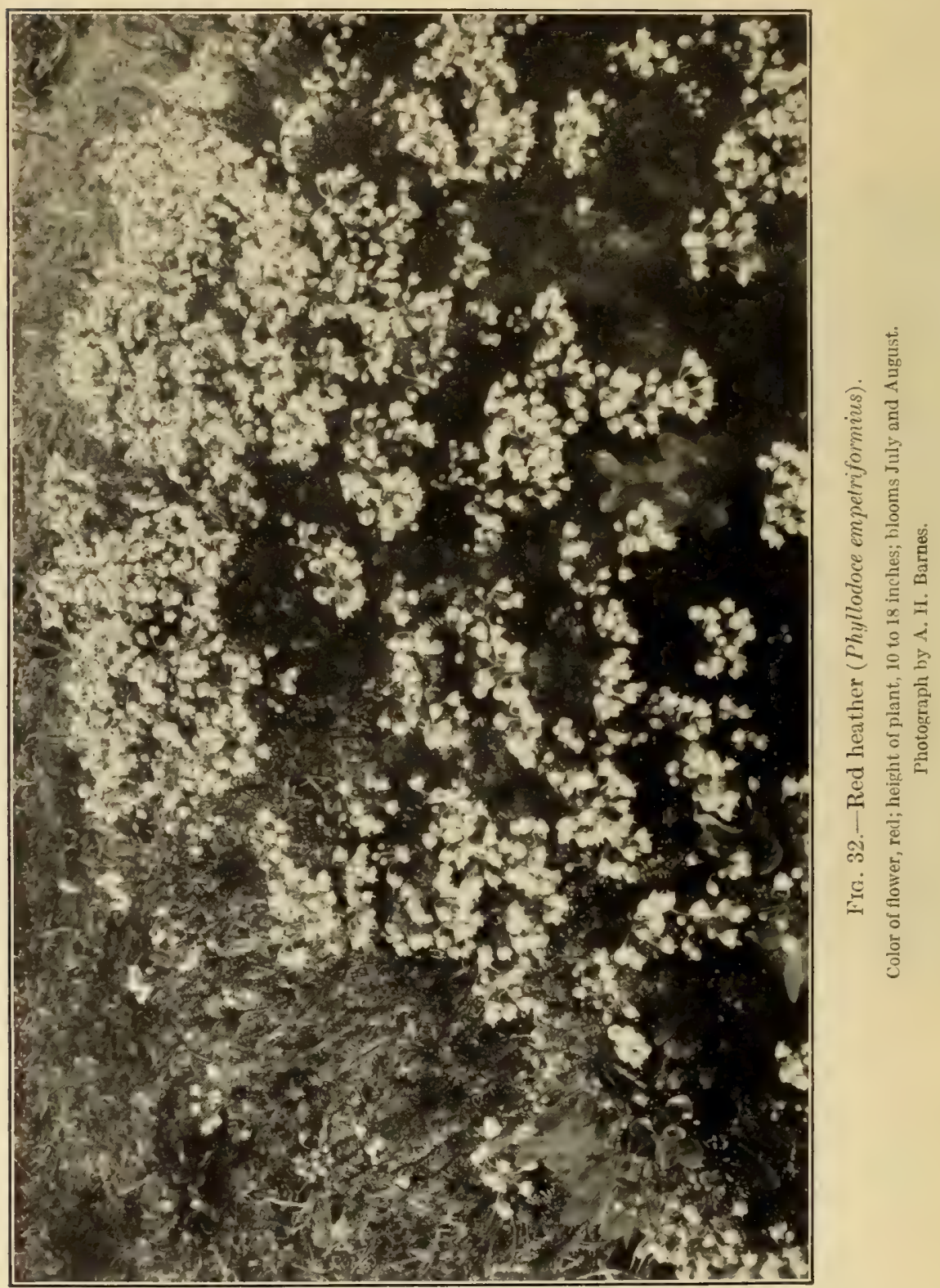

former. These plants are related to the Swiss edelweiss. They do not have the star like hearls of the Swiss plant. The dog riolet, Viola retroscabra, and the early violet, Viola sempervirens, are found 


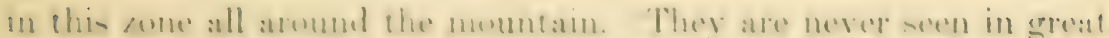

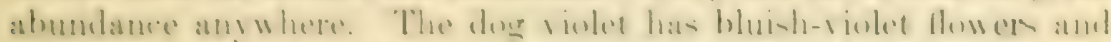

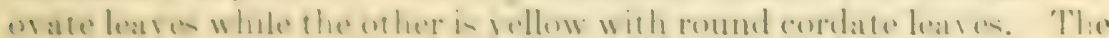
formere is mores abumlant than the latter. 'The pink family lats

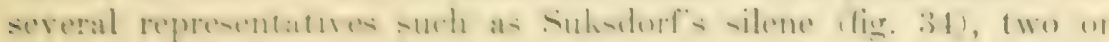

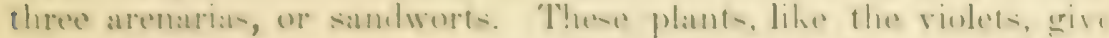

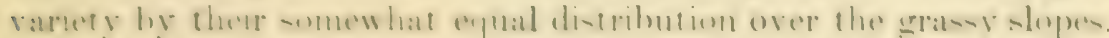

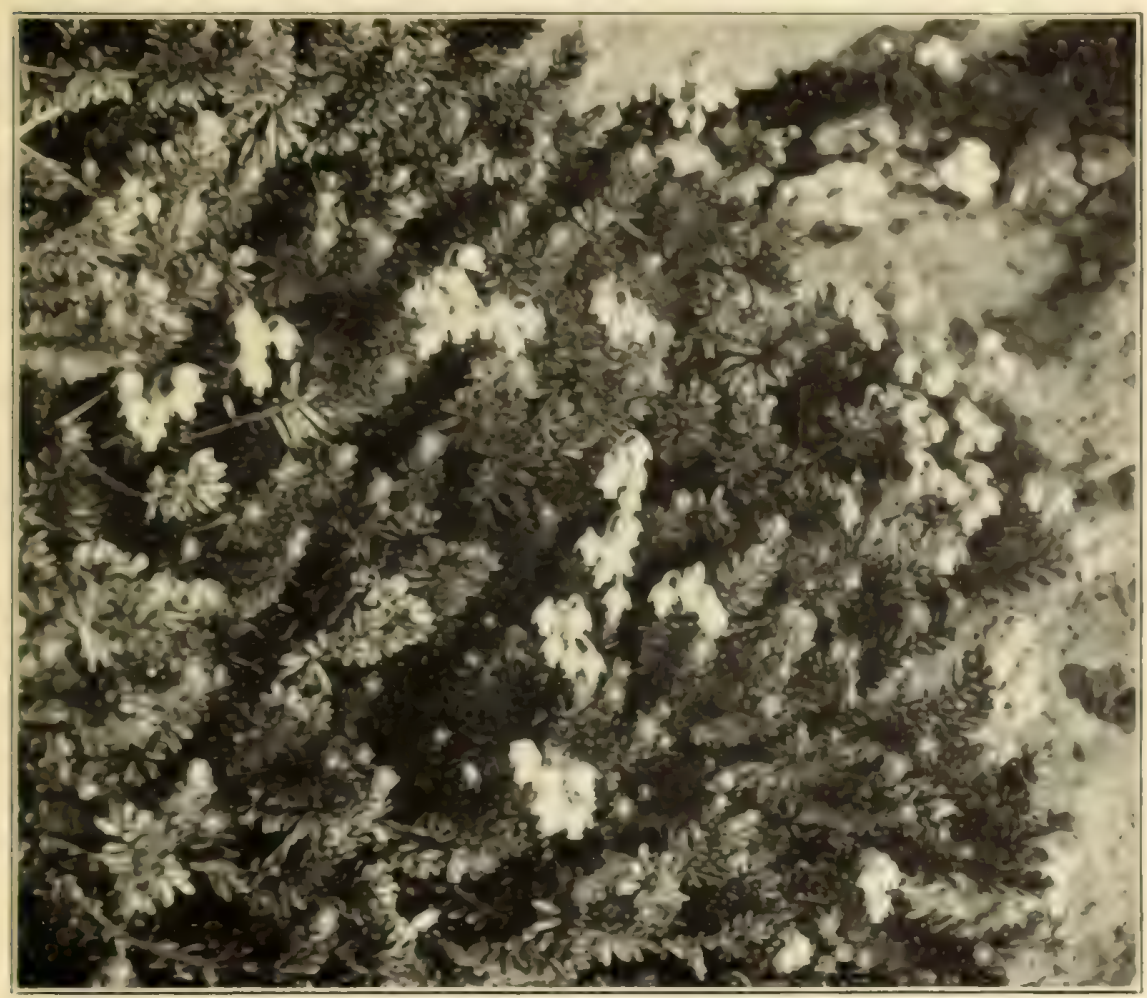

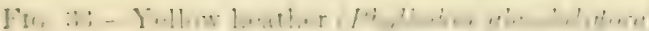

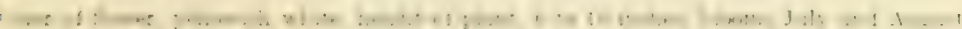

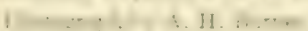

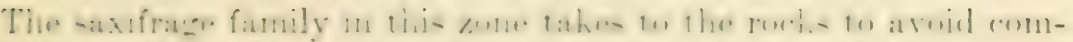

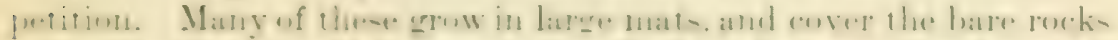

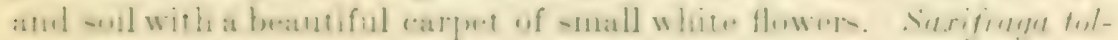

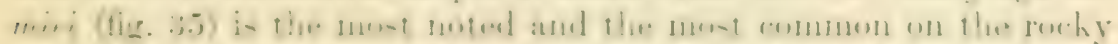

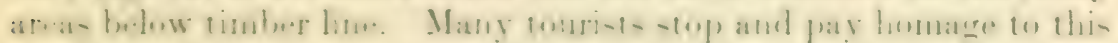

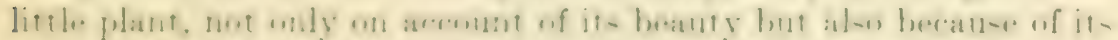

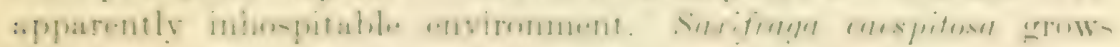
mure on moist crags and in still denser and more clobular masses thum

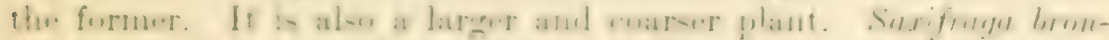

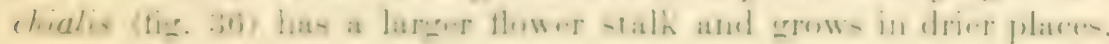




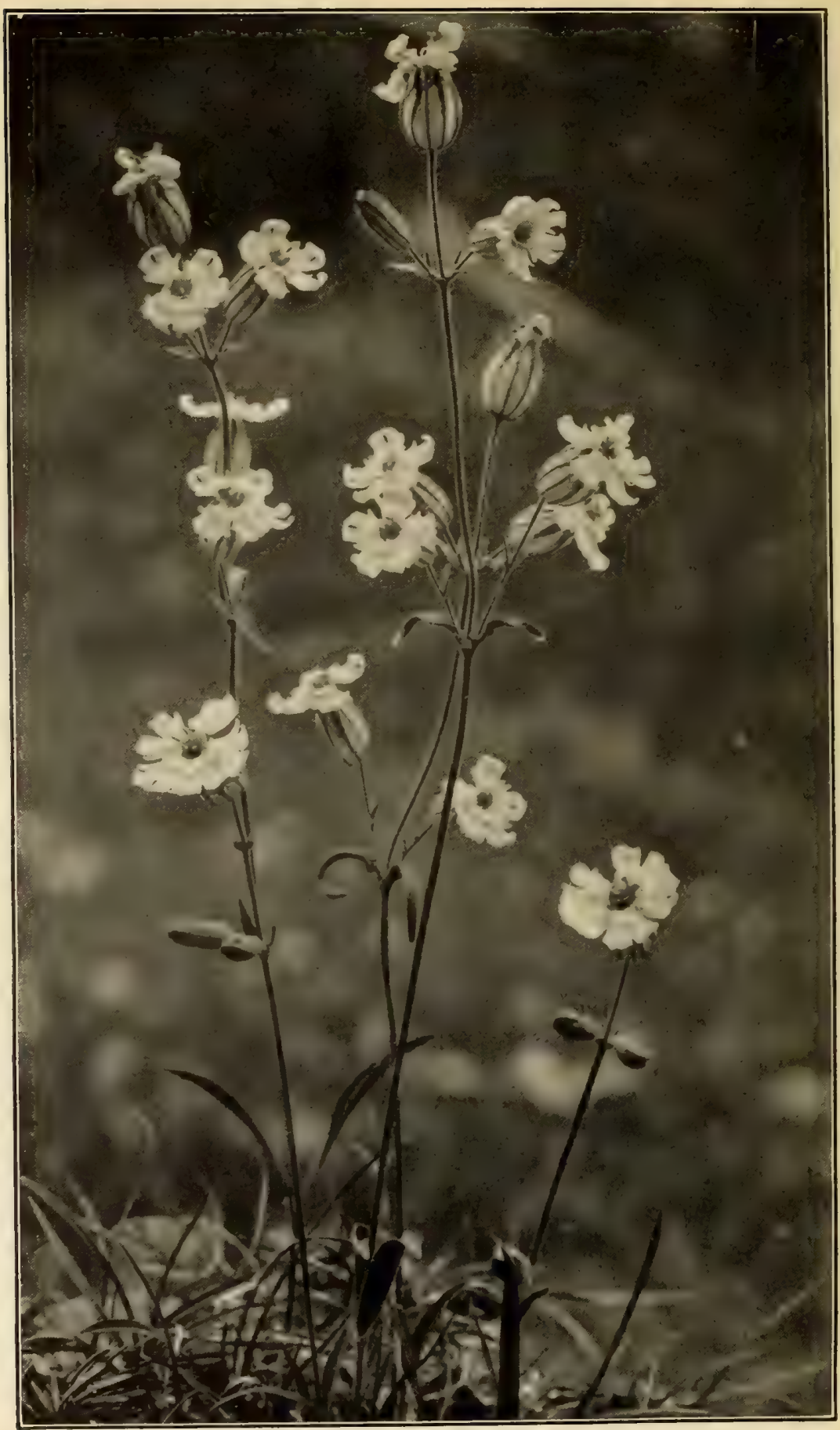

FIG. 34-Suksdorf's silene (Silene suksdorfii).

Color of flower, pinkish white; height of plant, 3 to 6 inches; blooms July and August. Photograph by A. H. Barnes. 


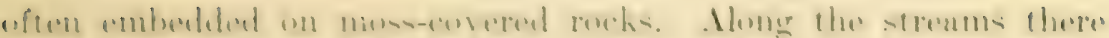

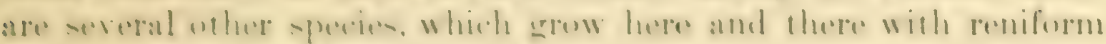
loaves and small whito flowors.

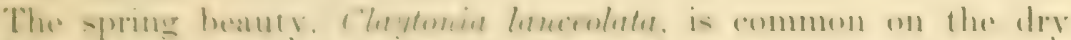

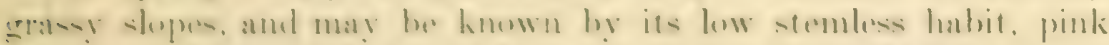

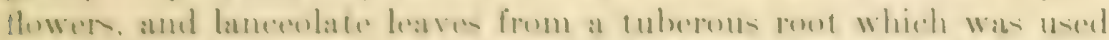

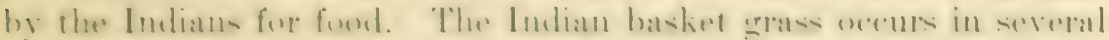

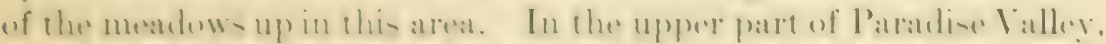

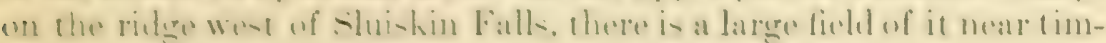

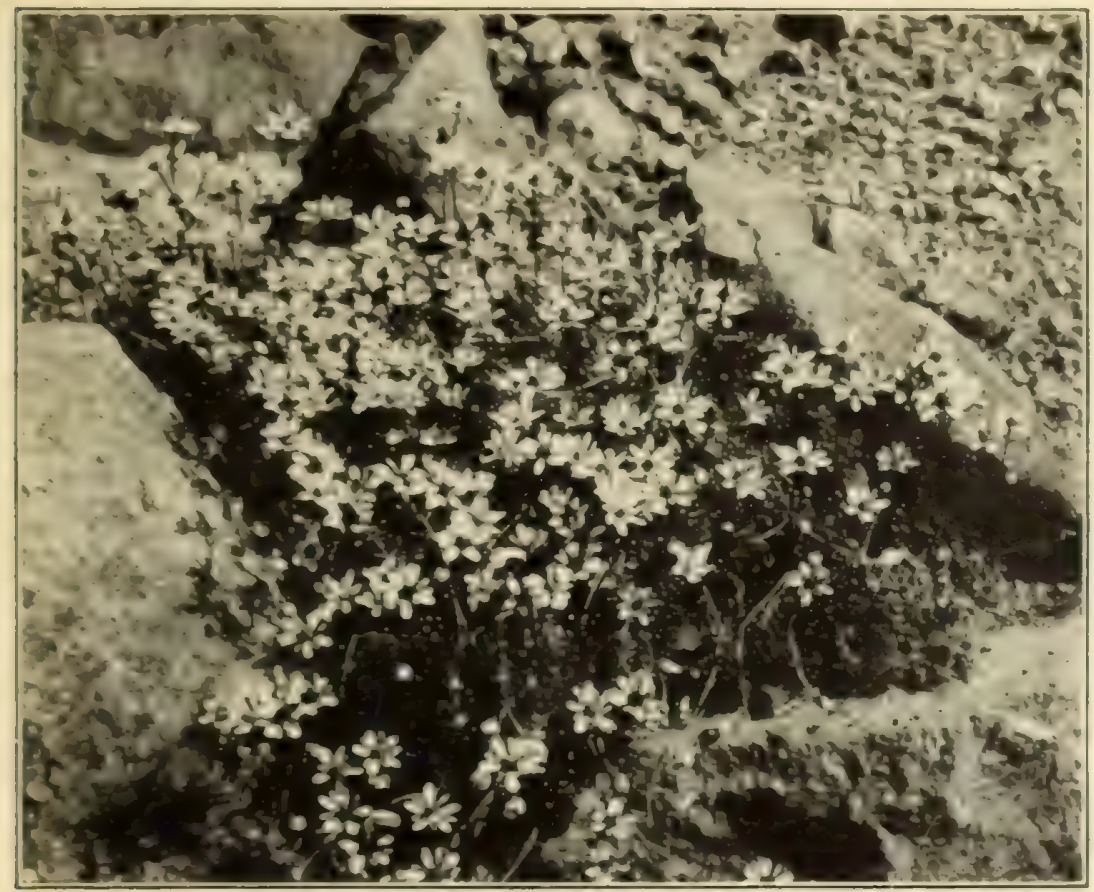

Fra. 35.-Tolmie's saxifraga (Saxifraga tolmiei).

Calor of flower. white. heisht of plant, 3 to 4 inches; tolooms July and August.

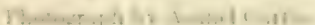

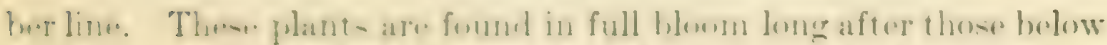

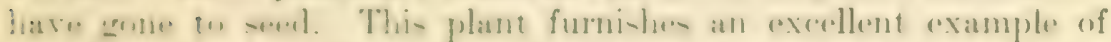

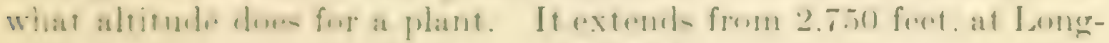
mire Springs, to timber line, about 7,000 feet.

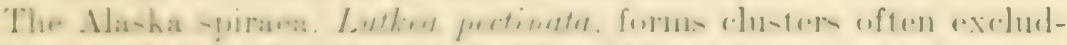

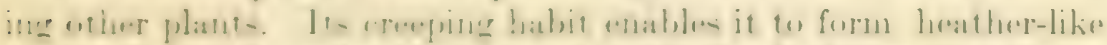

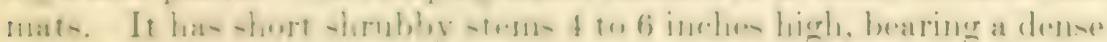

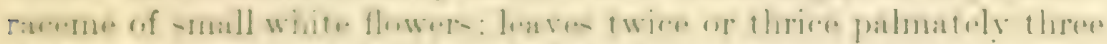

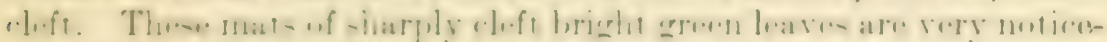

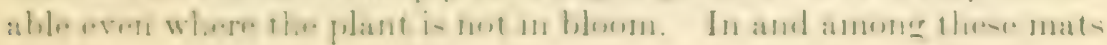


of Mlaska spiraea and heather grows a small form of the pale laurel not more than 2 to 4 inches high. It may be known by its saucershaped pink flowers, with pouches for the stamens, and by its ovate to lanceolate leaves, dark green above and whitish beneath.

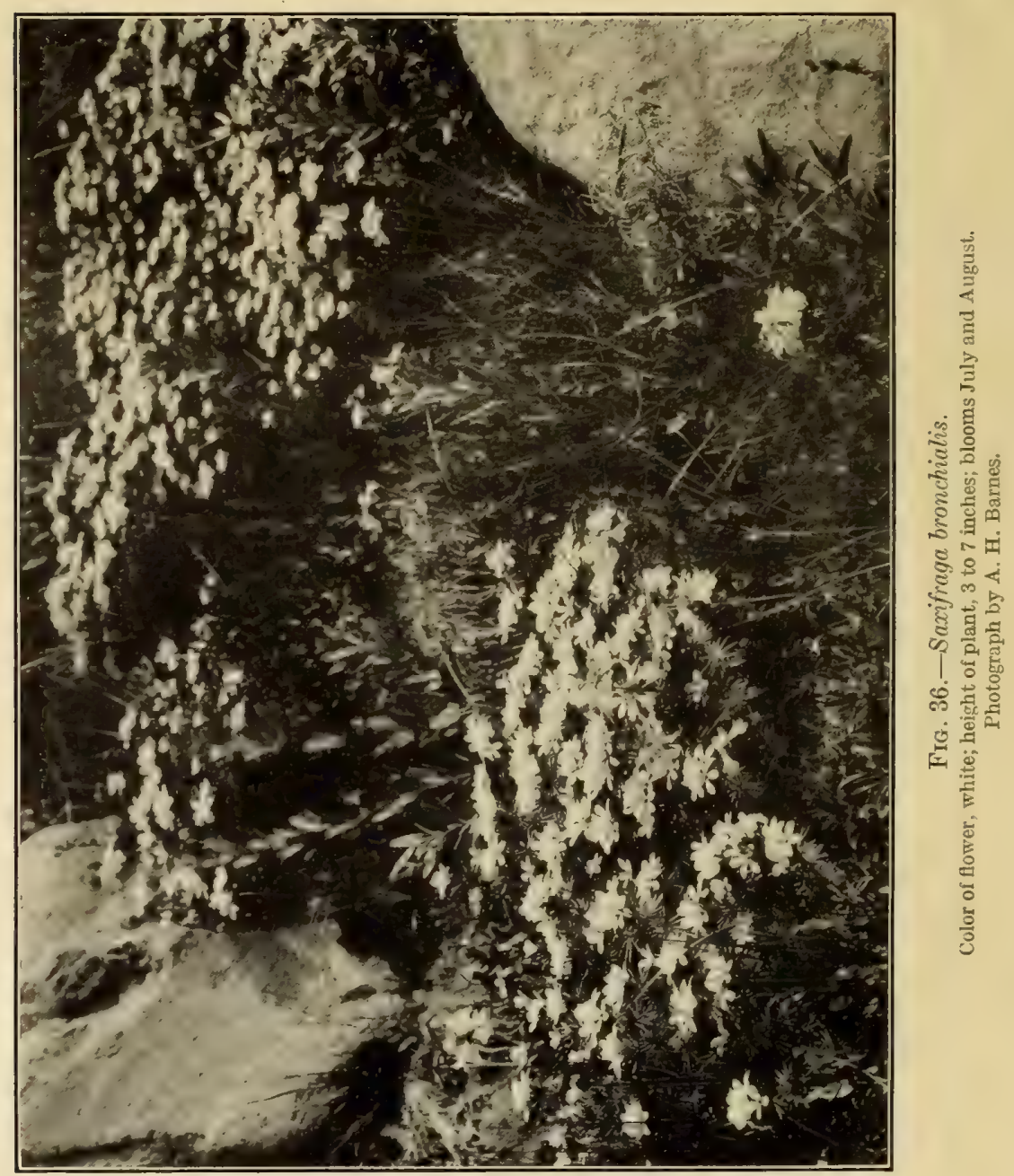

THE FOURTH ZONE.

The trees which reach timber line are the alpine fir, the alpine hemlock, the Alaska cedar, and the white-barked pine. There are a few gnarled specimens of the latter on the ridges west of Sluiskin Falls, but the alpine fir, alpine hemlock, and Alaska cedar are the common trees. The trailing juniper, Juniperus communis sibirica, is common at timber line and extends down far below, trailing over rocky ledges. Its trailing habit, sharp foliage, and green berries 


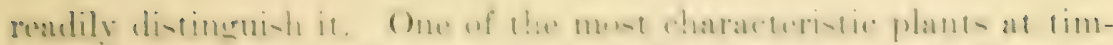

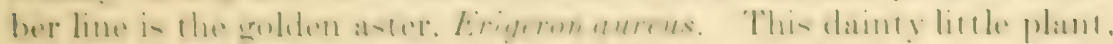

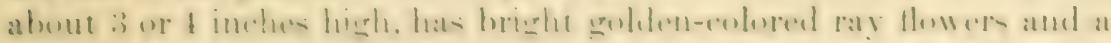

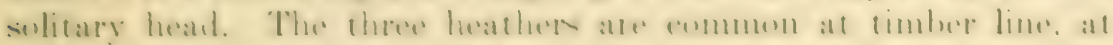

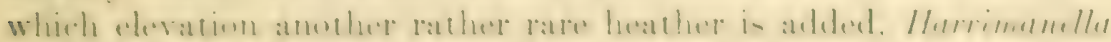

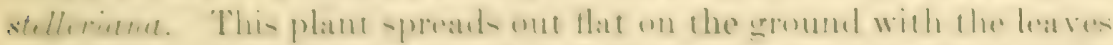

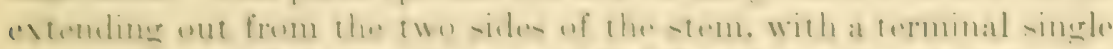

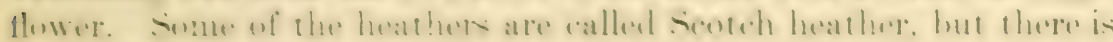

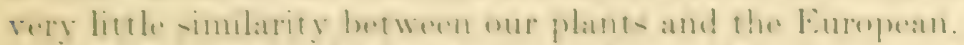

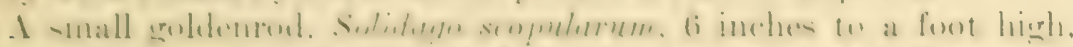

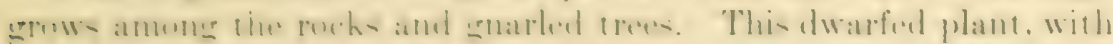

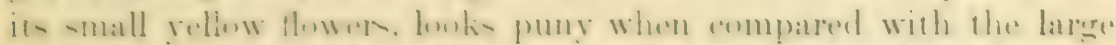

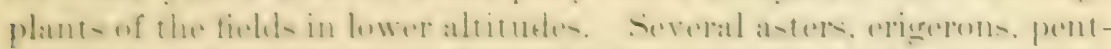

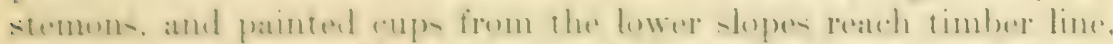

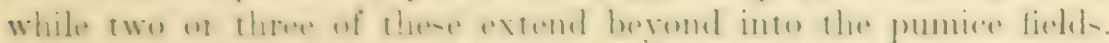

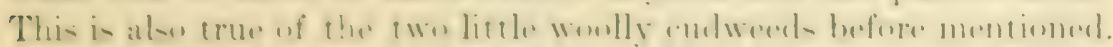

\section{THE FIFTH ZONE.}

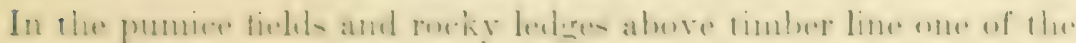

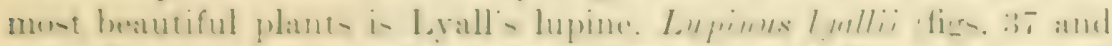

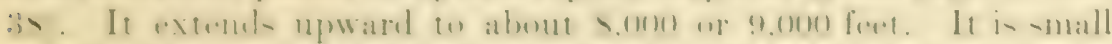

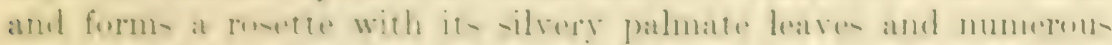

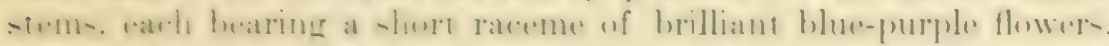

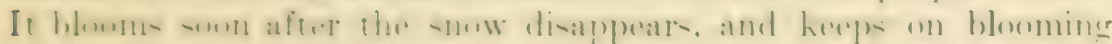

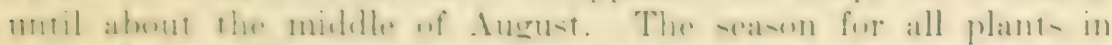

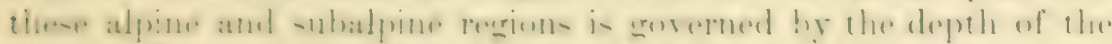

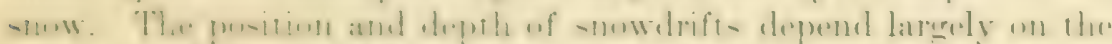

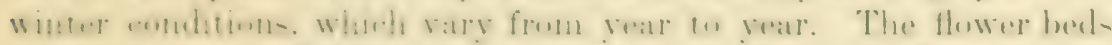

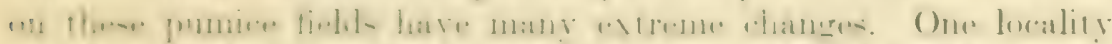

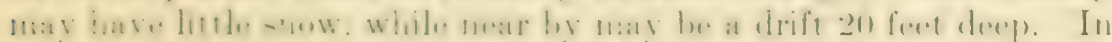

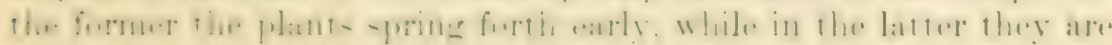

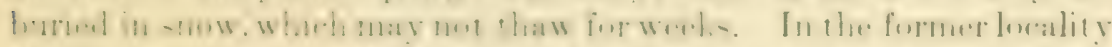

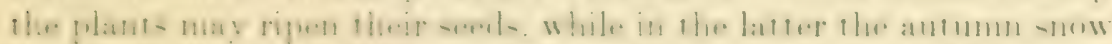

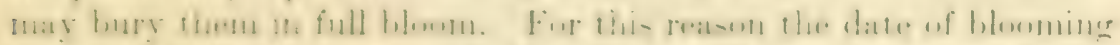

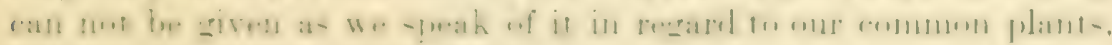
which rary comparatively little.

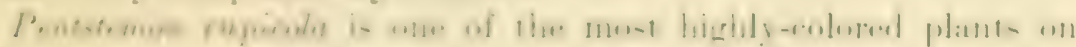

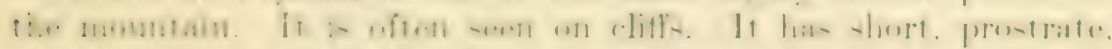

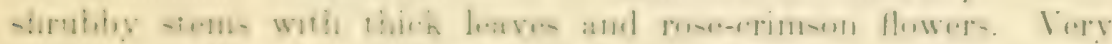

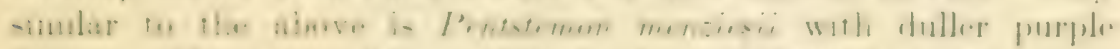

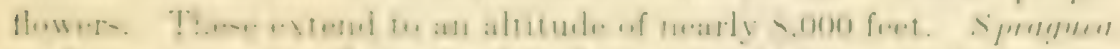

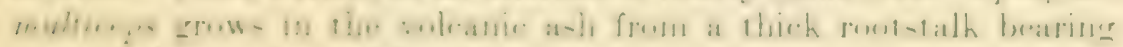

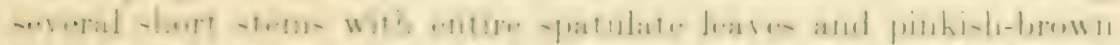

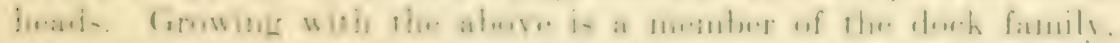

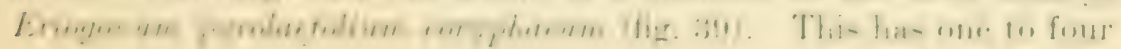


flowers of a purplish yellow color in an umbel with short flower stalks and thick oblong leaves. Polygonum newberryi belongs to the same family as the above. It may be known by its somewhat prostrate habit, rather fleshy ovate leaves, and small greenish flowers.

On the storm-swept peaks and ridges in the crevices of the rock may be found the tiny lace fern, Cheilanthes gracillima, with its numerous thread-like roots securely anchored from the fury of the storms. It is seldom more than 3 or 4 inches high. Nature has made ample provision for its inclement environment by clothing it with a furry woolly garment. It is found on the summit of Pinnacle Peak and on Plummer Peak. Sometimes it is found as low as

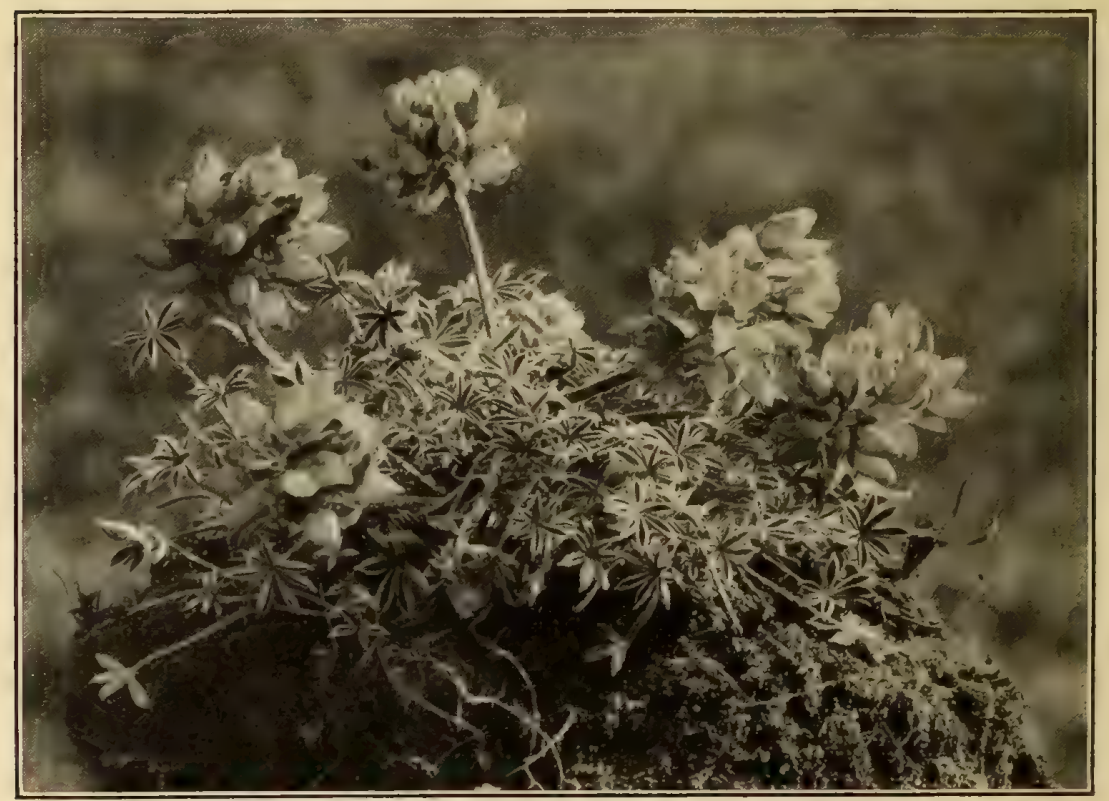

FIG. 37.-Lyall's lupine (Lupinus lyalliii).

Color of flower, bluish purple; height of plant, 2 to 7 inches; blooms July and August.

I'hotograph by $\mathrm{A}$. H. Barnes.

the peaks overlooking the terminal moraines of the glaciers and the rocky pinnacles above the road leading from Narada Falls to the Nisqually. Its companion plants are the mountain polypody, Polypodium hesperium, the kinnikinnik, Arctostaphylos uva-ursi and Pentstemon oreopola. Sometimes Phlox diffusa is woven in and out among them. $A$ study of any one of these peaks is extremely interesting, whether the student be a botanist or not.

Competing with Lyall's lupine for first rank as to beauty of foliage and brilliancy of flower is Phacelia sericea, an elegant plant of the water-leaf family. It may be known by its silvery foliage and purplish flowers, stem leafy to the top and leaves pinnately parted 


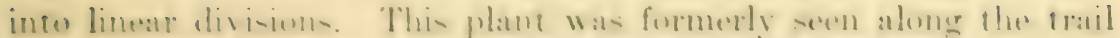

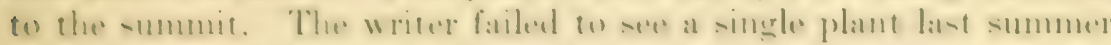

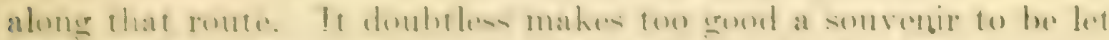

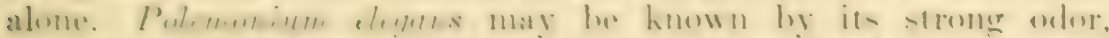

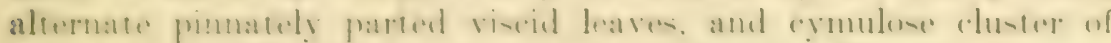

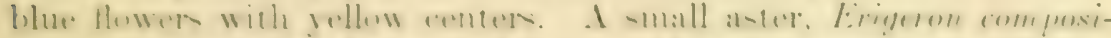

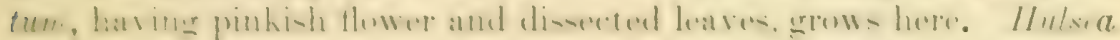

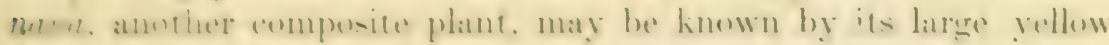
flowers. 2 to 6 inches high, with sticky pinnatifid leares, mostly

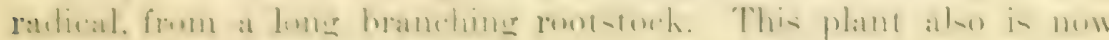

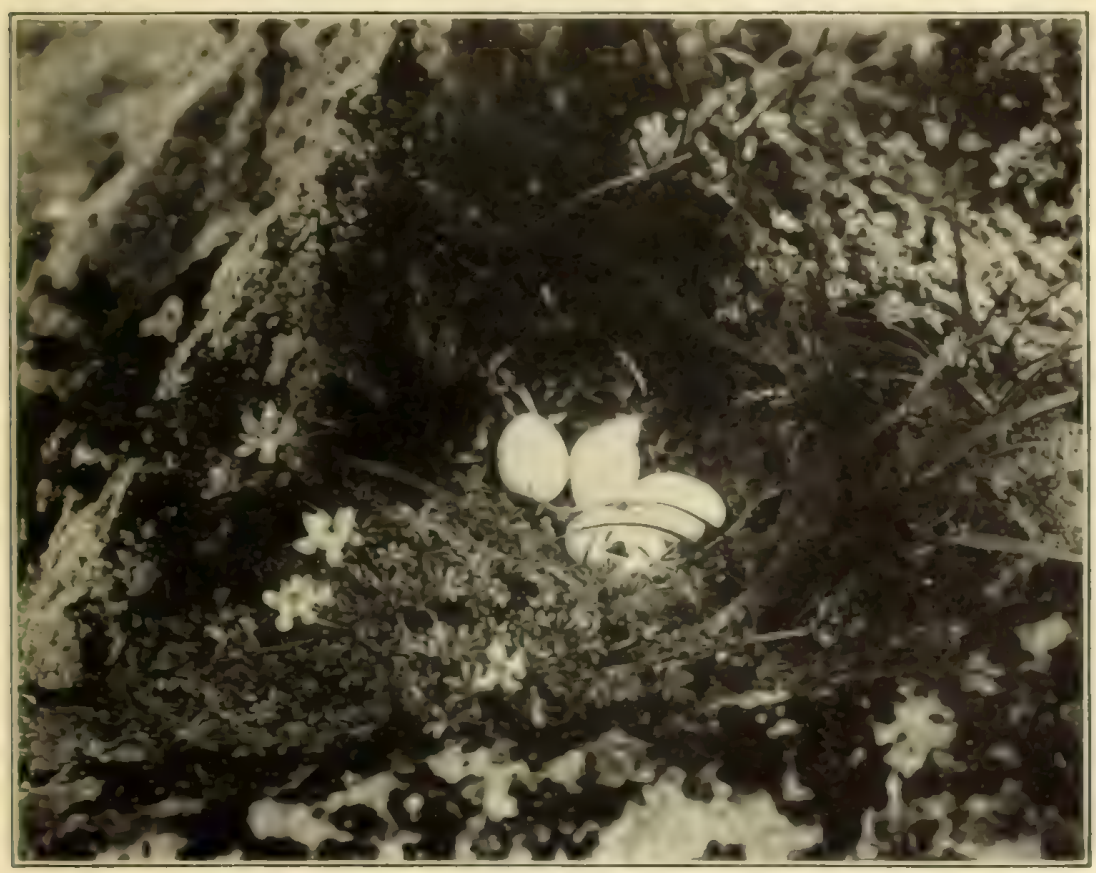

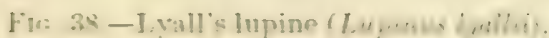

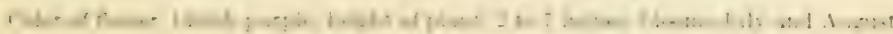

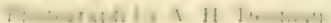

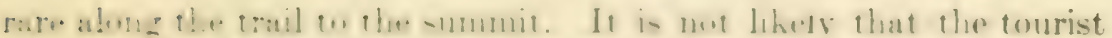

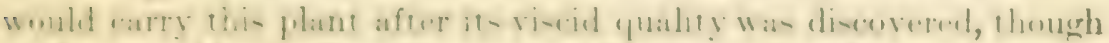

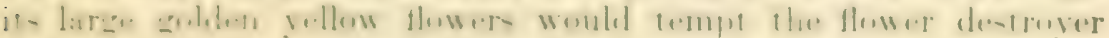
1.. whenk is

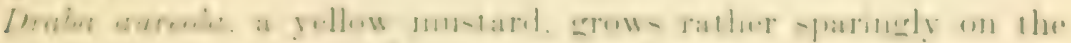
r.....s latges at Cump Mlair and at similar altitudes around the

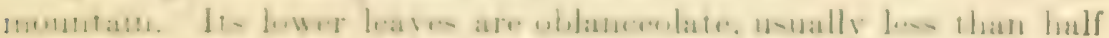
an wh hing, and the upper are oblong. It is densely pubescent all

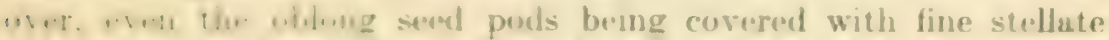

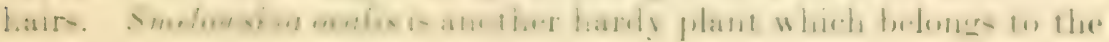


mustard family. It has hoary white foliage, creamy white flowers in terminal racemes and pinnatifid leaves. These two cruciferous plants just mentioned reach a higher altitude than do any other

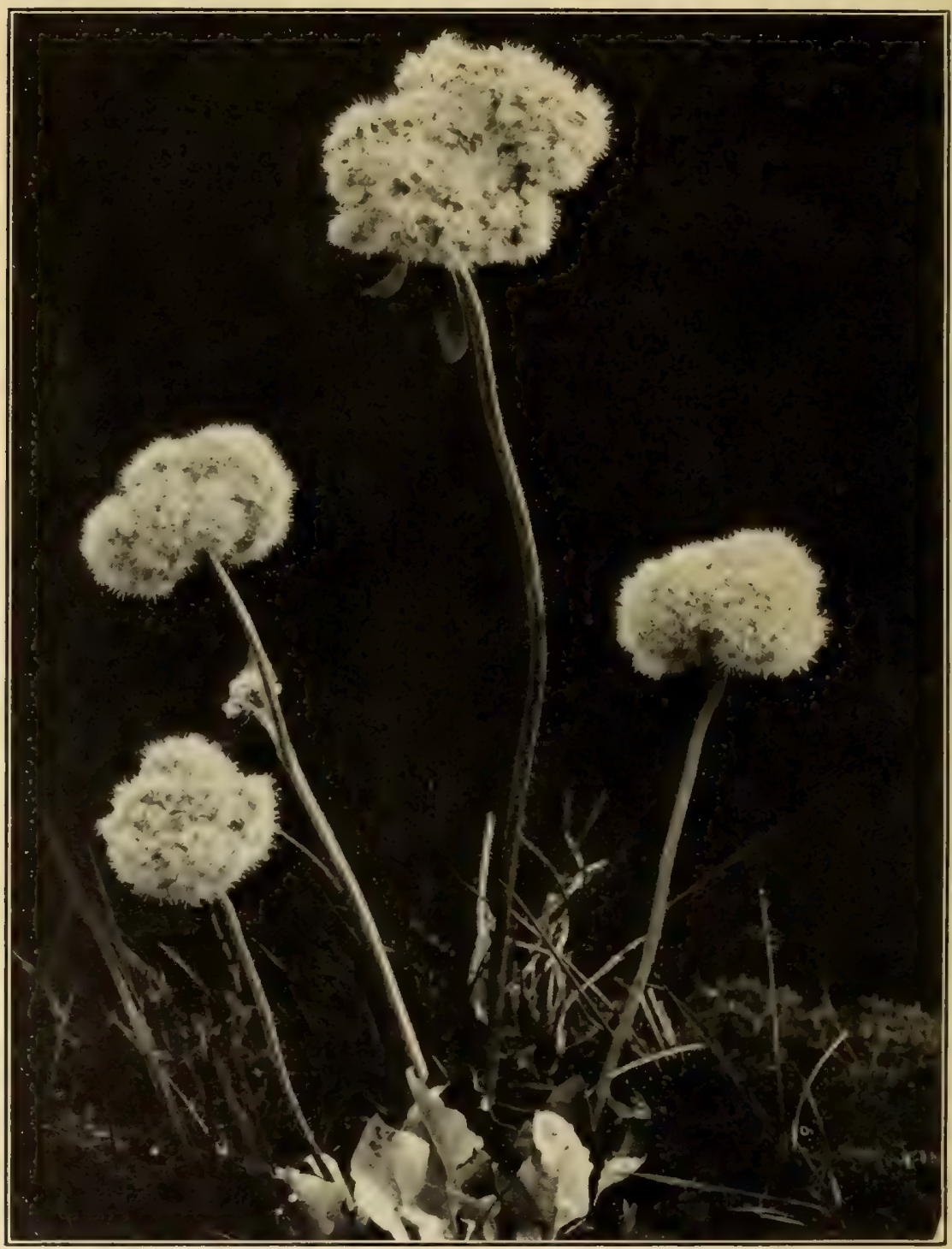

Fig. 39.-Eriogonum pyrolaefolium coryphaeum.

Color of flower, yellowish purple; height of plant, 3 to 8 inches; blooms July and August. Photograph by A. H. Barnes.

flowering plants on the mountain. Perhaps the smelowskia beats its companion a little. Two grasses, Poa lettermani, Poa sukstorfii, and a sedge are close competitors for the highest honors. 


\section{INDEX TO SPECIES.}

[Roman numerals indieate deseriptions or references; italie numerals indicate iflustrations.]

A Bies amabil:

$$
\text { grandis. }
$$

Acklys tripalylo.

Adder's tongue

A coveris el pestris.

A haska cedar. spirsea.

Alder.

illotroges ringento

Alplne beauty.
fir .........
44,45 $\lim _{20}$

willow

4 nemone dritoided

$$
\text { accidentalis. }
$$

Anemone, western.

A ntrnanaria lanato.

$$
\text { media. }
$$

Aretic lupine .

Arctodaphlos turg-ursi.

A rnica parryi.

Ash, mountain

Aster, solden

$$
\text { purple... }
$$

Barber's pole.

Bikukulla formong

Bird's-foot bramble.

Bishop's cap.

Bear iracs.

Black pine.

notang.

Blue gentian.

Brake.

Bramble, bind s-soot

$$
\text { snowy. }
$$

Brosd-lesifed maple

Bunchberry, Sec Canada dogrwood.

Buttereup. Sulpelorf's..

Buttercup, sus

Cansdas dogwood.

Otpnoides acowleri.

Caseara.

Castilleid ........

mertenaiat

orropole

Cedar, Alasks.

$$
\text { white... }
$$

Cheilenthes grocillit

Clartonia Inscrolata

Clintonic seniflors.

Cornl root .

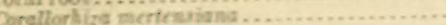

$$
\text { multiflort. }
$$

$$
\text { striate. }
$$

Conpur conaderais.

Cotton Rrase.

Cottonwood

Cud wreeds.

Curront, movintait

Crusick's speedwell.

evthered beiboes

Dandelion, mocintain.

Deer fern

Deertoncue, while mountain

Derril's clab.

Dock, mountain.

Dodecentacos jefrecit.

Dog's-tcoth violet

Dog violet.

Docmood, Cansda

Dovichas fir

Dourlas spitree.
2,13

2,13

19

23,24

$12,35,44$

44

4,8

$8,8,9$ 9,10 4, 27, 28
Drabn gurcola..................................... 47

Pruopteris spinulasa dilatata.

Behinopgnar horridum

Bdelweis

Elk krass................................ 17,

Spilobium luteum............................

Erigeron aurcus................................

compasifum m................................ 45,48

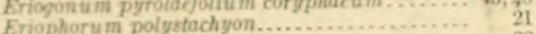

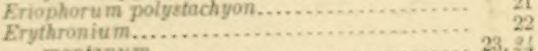

montanum............................. 23,24

Bucenhalus ledophylus....................... ii 21,23

Ferns ................................. $11,12,46$

Fir, alpine ............................... $35,44,45$

Douglas ...........................

lovely ........................

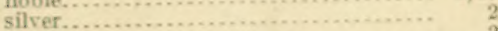

white

Fireweed, yellow ............................. $8,8,9$

Forest anemone......................... $8,8,8$

Gautherid otatijotia............................... 35,37

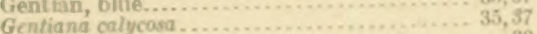

Gilig nuttallif.............................. 39

Ghost plant......................... 3,3

Golden aster.................................

Goldenrod................................ 17, 1 .

Grass, bear ................................... 17,

cotton............................... 17,17

elk .................................... 17, 17

Grass of Parnassus

Harrimanella stelleriana ...................... $38,89.49$

Heather, red........................... 38,39 , 8

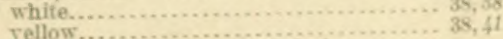

Heliotrope, mountain. Se Valerian.

Hellebore. .......

Hemitomes congestum...................... 4,5

Hemlock, alpine............................. 13

lowland ..............................

lowland, western........................

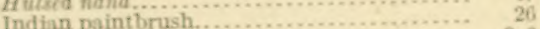

Indian pipe .............................. 3,3

Junipcrus communis sibirica ................. 44

Kinnikinnik .............................. 46

Lace fern................................. ${ }_{22}^{46}$

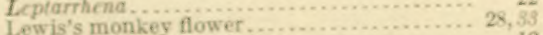

Licorice fern................................... ${ }_{30}$

Ligusticum purpurcum......................... 23, 30

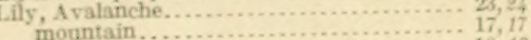

Linnead americana............................. 16, 16

Lousewort............................ 18, 18

Lovely fir. ...............................

Lowland hemlock.........................

western hemlock........................

Gupinus Irallii.......................... 45,46 . 4 ?

subalptnus............................. 25, 31

Luiterg pectinala........................... 43

Lyall's lupine..........................4 $46,46,47$

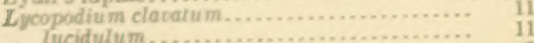

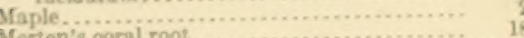

Merten's coral root............................. 25,30

Mimuju elpinu............................ 28,38 


\section{INDEX TO SPECIES.}

Mithela

Moneses uniflor

Monkey flower

Monotropa unifiora.

Mountain ash

currant....

dandel

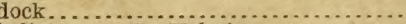

heliotrope. See Valerian.

lily...

phlox...

polypody.

Noble fir

Oregon wood sorrel

Oxalis oregona

Paintbrush, Indian

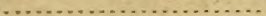

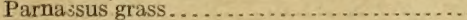

Parsnip, wild

Pedicularis. rontorta.

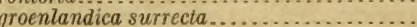

remon confertus

menziesii

oreopola.

procerus

rupicola...

Phegopteris dryopteris .......... 12

Phlox diff $u$ sa......................... $35,86,46$

Phyllodoce empetriformis ..................... 38, 39,40

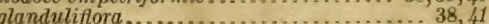

Pine, black.......................... 12

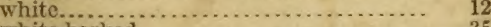

white-barked.................. 35

Pine sap................................ $\quad 4,5$

Pinus albicaulis........................... $\quad 35$

psissewas............................ 6, 18

a lettermani.......................... 48 suksdorf

Polemonium elegans. pulchellum........................... 25, 38

Polygonum bistortoides ................... 30,34 newberryi........................... 46

Polypodium hesperium................... 46 occidentale

Polypody, mountain

Potentilla flabcllifolia........................ 23, 26, 35

Prince's pine.

Pterospora andromedea.

Pulsatilla occidentalis ........................... $4,27,28$

Purple aster.......................... 21, 22

Pyrola.

a phylla.

bracteata.

picta...$$
\text { secunda }
$$

Ranunculus suksdorfi

Red heather.

Ribes acrifolium

Rosy spiraea.
Rubus lasiococcus

nivalis .

pedatus.......................... 19

Salal..............

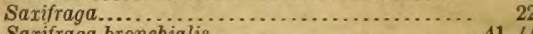

Saxifraga bronchialis................. 41, 4

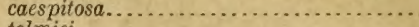

tolmiei.

41, 45

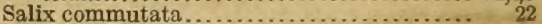

Seed pods of anemone. . . . . . . . . . . . . . . . .

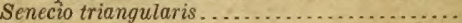

Shooting star ........................ 20,

Silene suksdorfi

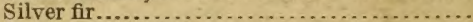

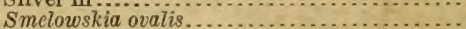

Snowy bramble.

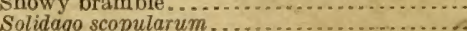

Sorbus occidentalis . - -

Speedwell, Cusick's .................... 25,

Spiraea, Alaska ........................

Spiraea densiflora

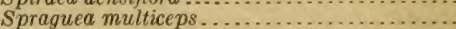

Spring botuty

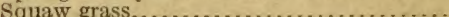

Struthiopteris spicant.

Suksdorf's buttercup -

silene buttercup -

silene.............

Sweet clover.

wiss edelweiss.

Sword fern

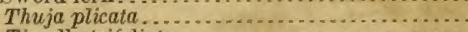

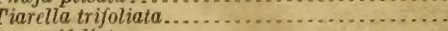
unifoliata.

Tolmie's saxifrage.

Trailing juniper.

Twin flower

Usnea.

Valerian................................. 25, 13

Valeriana sitchensis . . ................... 25, 29

Vanilla leaf........................ 19

Veratrum viride ....................... 32

Veronica cusickii...................... 25, 35

Vine maple................................

Viola retroscabra ........................ $\quad 40$

sempervirens...............

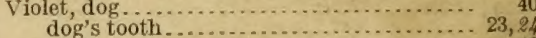
dog's tooth ......................... 23, 24

Western hemlock................................ ${ }^{2}$ anemone $\ldots \ldots \ldots \ldots \ldots \ldots .8,9,10,24,27,28$

White-barked pine ....................... 35,44

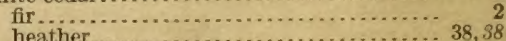

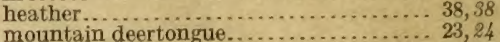
mountain deertongue.............. 23, 24 pine................................... illow, common Alpine.................. 22

Wintergreen, or Pyrola $\ldots \ldots \ldots \ldots \ldots \ldots . . .4$

Wintergreen, or Pyrola.................................. 17

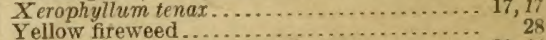

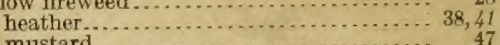




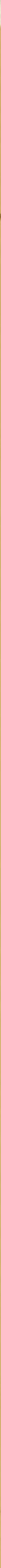
. 


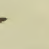

